Portland State University

PDXScholar

\title{
Factors Influencing Oviposition Among Pond- Breeding Amphibians: Exotic Vegetation, Oviposition Braces, and Cover
}

Catherine Mary Callison

Portland State University

Follow this and additional works at: https://pdxscholar.library.pdx.edu/open_access_etds

Part of the Biology Commons, and the Ecology and Evolutionary Biology Commons Let us know how access to this document benefits you.

\section{Recommended Citation}

Callison, Catherine Mary, "Factors Influencing Oviposition Among Pond-Breeding Amphibians: Exotic Vegetation, Oviposition Braces, and Cover" (2001). Dissertations and Theses. Paper 4333.

https://doi.org/10.15760/etd.6221

This Thesis is brought to you for free and open access. It has been accepted for inclusion in Dissertations and Theses by an authorized administrator of PDXScholar. Please contact us if we can make this document more accessible: pdxscholar@pdx.edu. 


\section{THESIS APPROVAL}

The abstract and thesis of Catherine Mary Callison for the Master of Science in

Biology were presented July 18,2001 , and accepted by the thesis committee and the department.

COMMITTEE APPROVALS:

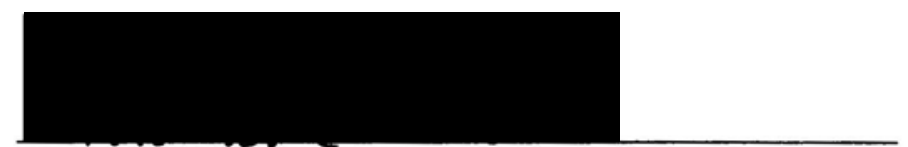

Richard Forbes, Chair

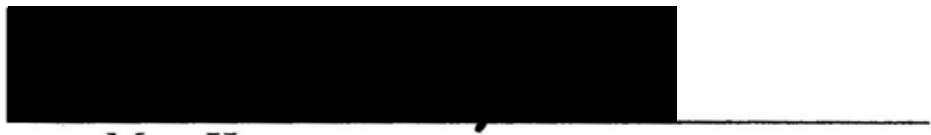

Marc Hayes
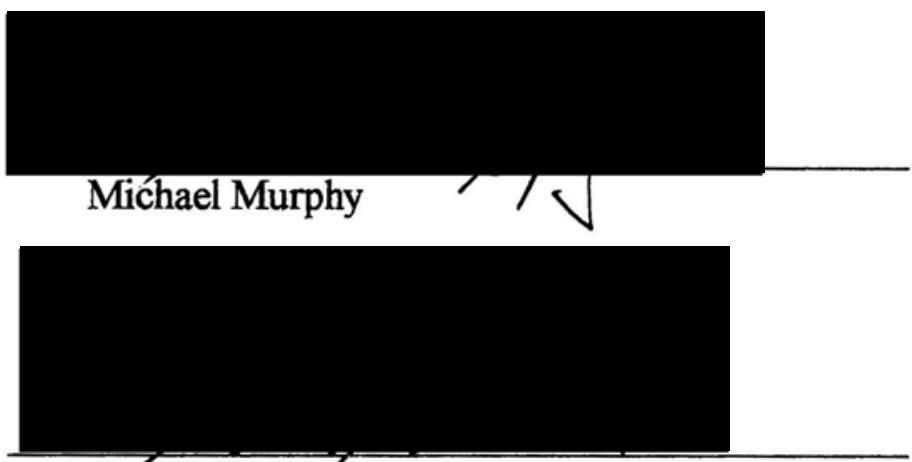

Stanley Hillman

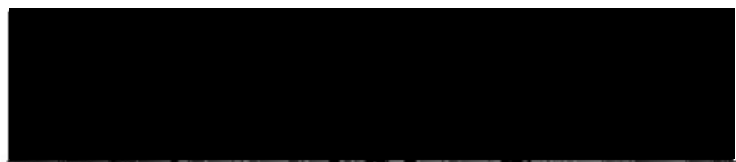

Ric Vrana

Representative of the Office of Graduate Studies

DEPARTMENT APPROVAL:

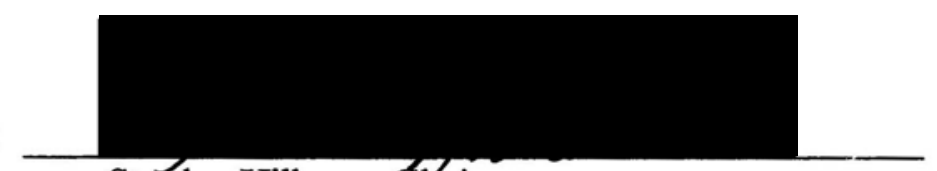

Stanley Hillman, Chair

Department of Biology 


\begin{abstract}
An abstract of the thesis of Catherine Mary Callison for the Master of Science in Biology presented July 18, 2001.

Title: Factors Influencing Oviposition Among Pond-Breeding Amphibians: Exotic Vegetation, Oviposition Braces, and Cover.
\end{abstract}

I examined oviposition in four pond-breeding amphibians (northwestern salamander [Ambystoma gracile], long-toed salamander [Ambystoma macrodactylum], Pacific treefrog [Hyla regilla], northern red-legged frog [Rana aurora aurora]), at Burlington Bottoms, a lowland riverine site in northwestern Oregon, to determine whether differential use of native versus exotic plant substrates occurs. I found differential use in all four species, but use was inconsistent with the hypothesis that selection for native plants (or selection against exotic plants) was occurring. If selection was occurring, the pattern implied that reed canarygrass (Phalaris arundinacea), a widespread exotic in this lowland system, was sometimes favored. However, inconsistent use of reed canarygrass led me to examine the alternative that substrate strength (measured as density, diameter, and mass), rather than plant status, might be the basis of selection. Species used for oviposition differed in strength, but eggs were not consistently laid on braces based on my strength measures. Failure to find support for this hypothesis led to examination of a third hypothesis for two 
species (red-legged frog and northwestern salamander), that cover characteristics of the oviposition brace or nearby vegetation might influence egg mass location. Analysis of structural complexity of species used as a brace (as percent cover within $15 \mathrm{~cm}$ of the egg mass) did reveal a pattern consistent with complexity, but that was species-specific. Red-legged frogs selected braces with significantly more nearspace cover; northwestern salamanders selected braces with sparser cover. Comparison of marginal shrub and tree cover to the number of red-legged frog egg masses revealed that ponds with $<50 \%$ shrub/tree cover had few $(<5)$ masses.

Ponds with $\geq 50 \%$ shrub/tree cover had many $(\geq 10)$ masses. More complex vegetation may provide greater protection for egg masses or ovipositing red-legged frogs but further investigation is clearly warranted. Elucidating northwestern salamander cover requirements will require examining more occupied ponds. In particular, more refined examination, using experimental manipulation, is needed to verify the cover relationships revealed in this study. Meanwhile, managers should treat cover as important in red-legged frog oviposition life history, paying special attention to minimizing loss of marginal shrub and tree cover. 


\title{
FACTORS INFLUENCING OVIPOSITION AMONG
}

\section{POND-BREEDING AMPHIBIANS: EXOTIC VEGETATION, OVIPOSITION BRACES, AND COVER}

\author{
by \\ CATHERINE MARY CALLISON
}

A thesis submitted in partial fulfillment of the requirements for the degree of

\author{
MASTER OF SCIENCE \\ in \\ BIOLOGY
}

Portland State University

2001 


\section{Dedication}

In memory of my father, Richard Worth Coldren (1927-2000), and my brother, Peter Worth Coldren (1960-2000):

Two of my first teachers and supporters who gave me the courage to try new things and helped me believe in myself. 


\section{Acknowledgements}

This project highlighted the collaborative nature of science. I would like to thank Dr. Marc P. Hayes for helping develop this study and sharing so much of his expertise. Dr. Richard B. Forbes gave endless encouragement, advice, and help. The others on my thesis committee, Dr. Stanley S. Hillman, Dr. Michael T. Murphy, and Dr. Ric Vrana also spent many hours editing and giving good advice.

This project would not have been possible at all without Sue G.Beilke, wildlife biologist and project site manager for the Oregon Department of Fish and Wildlife, and her willingness to provide time, equipment, expertise, and volunteers.

The Oregon Zoo Foundation provided funds to purchase equipment. Additional equipment was borrowed from the PSU Biology, Environmental science, and Geology departments.

The amount of data collected required much assistance, and I will be forever grateful to the cheerful willingness of all my field assistants: Sarra L. Moller, Richard Y. Primmer, Anita M. Christenson, Denis M. O’Brien, Joe Maxey, Karen S.Sexton, Lisa D. Karst, Kyle Spinks, Adam R. Gallom, Rachel Sanchez, Shonene A. Scott, and Diana Gordon and her students from St. Mary's High School.

To all those people who helped me learn how to use Arcview software, understand GPS, and get my analysis done! Brady Callahan - ODFW, Sarra and Chris Moller, Shonene A. Scott, Lilian Herron, and Dr. Ric Vrana.

Thanks to Char C. Corkran for permission to use her photographs for some of the amphibians and egg masses.

The encouragement and love of my family kept me going throughout the whole process. They also gave formatting and editing help. Last, but certainly not least, my husband Brad. 


\section{Table of Contents}

Acknowledgements.......................................................................................

Table of Contents

List of Figures ........................................................................................

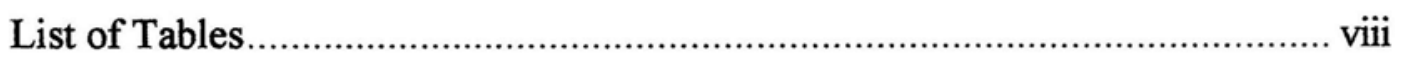

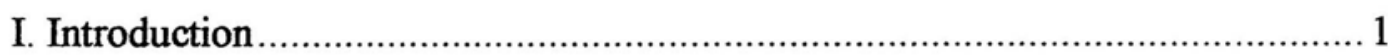

II. Study Species Natural History ................................................................ 6

Northern red-legged frog ........................................................................... 6

Northwestern salamander ........................................................................ 8

Pacific treefrog.............................................................................. 9

Long-toed Salamander …………………………………………............... 10

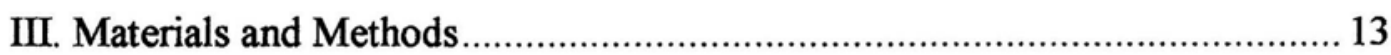

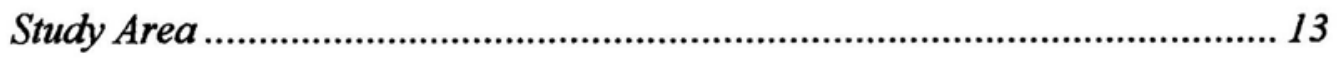

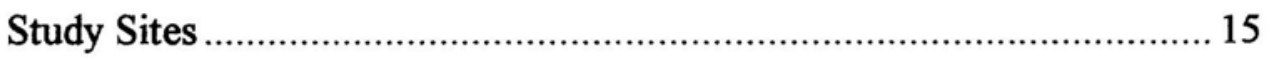

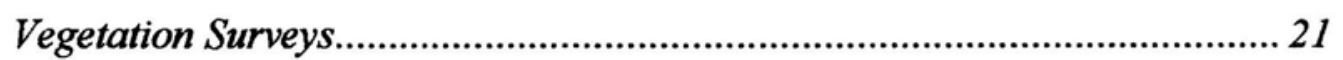

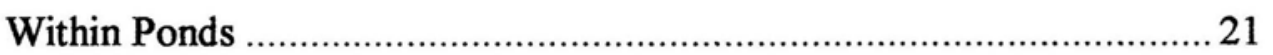

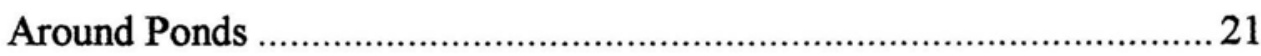

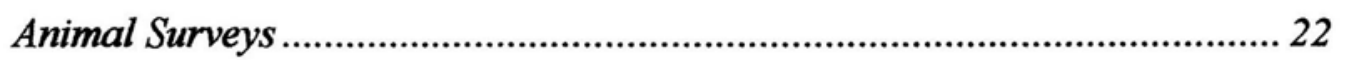

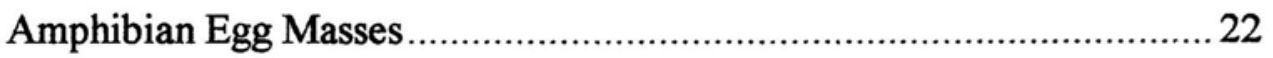

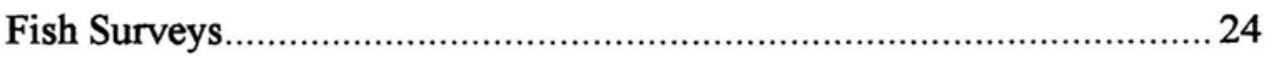

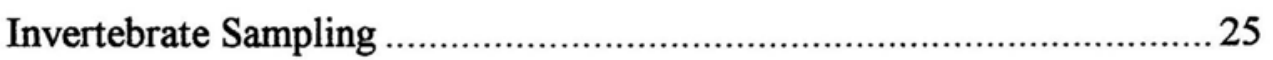

Water Quality Measurements .................................................................... 26 
Mapping

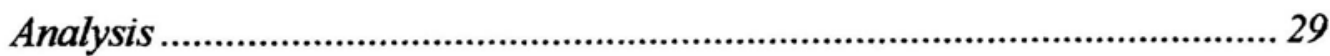

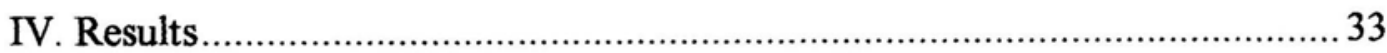

Pond Vegetation Composition ................................................................... 33

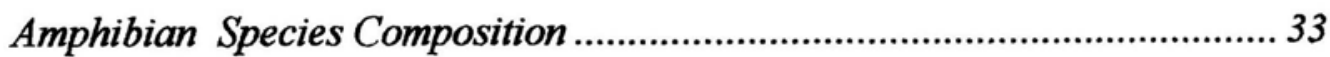

Exotic Vegetation Hypothesis................................................................. 40

Substrate Strength Hypothesis................................................................50

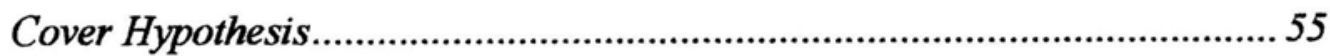

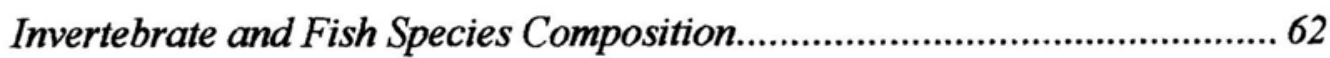

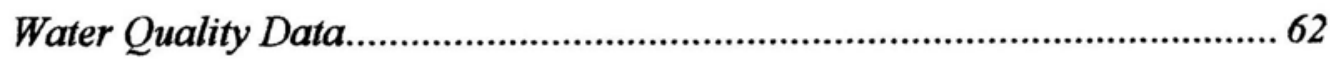

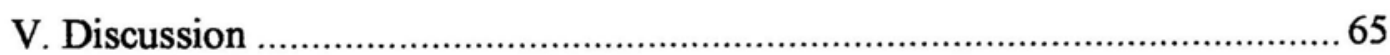

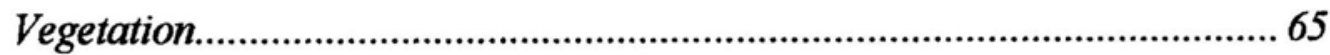

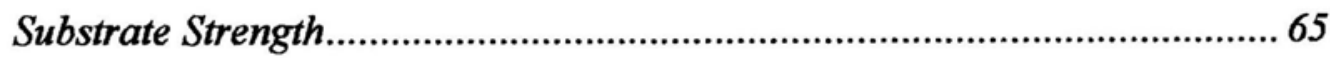

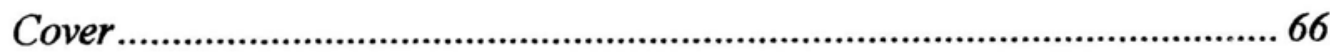

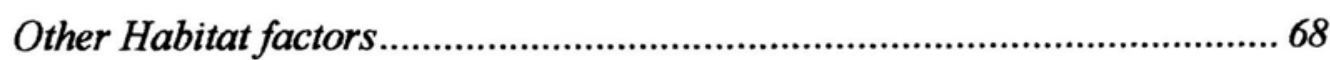

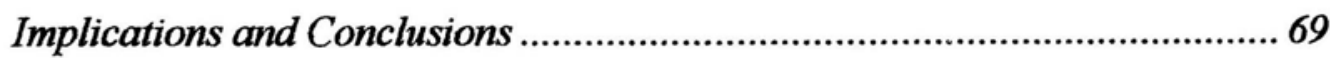

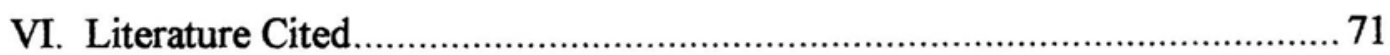

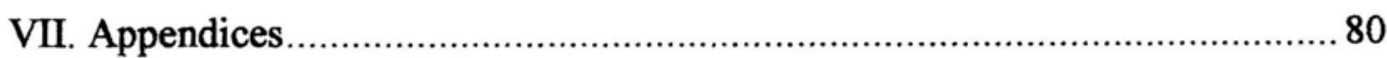

Appendix A - Burlington Bottoms Oviposition Study 2000 ......................... 80

Appendix B - Vegetation Survey Effort .................................................. 81

Appendix C - Survey Transects............................................................. 82

Appendix D: Egg Mass/Water Quality Survey Effort .................................8 89 
Appendix E: Mapping Vegetation and Pond Margins Effort ...................... 90

Appendix F: Data Sheet Used for Egg Mass Surveys............................... 91

Appendix G: Protocol for Egg Mass Surveys........................................... 92

Appendix H: Fish Sampling Schedule ....................................................... 93

Appendix I: Plant Species Addressed in This Study.................................... 94

Appendix J: Attachment Brace Variation.................................................... 95

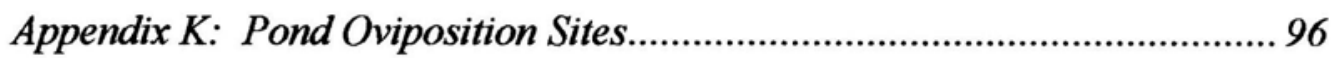

Appendix L: Macroinvertebrate Sampling Results.................................. 103

Appendix M: Minnow Trap Results ....................................................... 104

Appendix N: Hydrolab Water Quality Measurements.............................. 105 


\section{List of Figures}

Figure 1 - Northern red-legged frog / Egg mass of northern red-legged frog ... 12

Figure 2 - Northwestern salamander / Egg mass of northwestern salamander ... 12

Figure 3 - Pacific treefrog / Egg mass of Pacific treefrog.............................. 12

Figure 4 - Long-toed salamander / Egg mass of long-toed salamander.............. 12

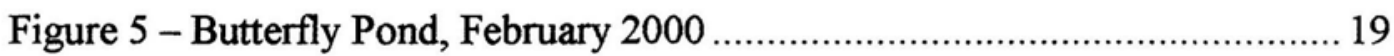

Figure 6 - Kidney Pond, September 1999 / Kidney Pond, February 2000 .......... 19

Figure 7 - Muskrat Pond, September 1999 / Muskrat Pond, March 2000 ........... 19

Figure 8 - Oak Pond, September 1999 / Oak Pond, March 2000 ...................... 19

Figure 9 - Pancreas Pond, September 1999 / Pancreas Pond, February 2000 .... 20

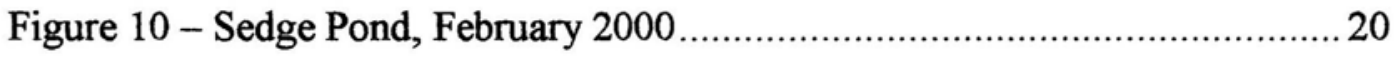

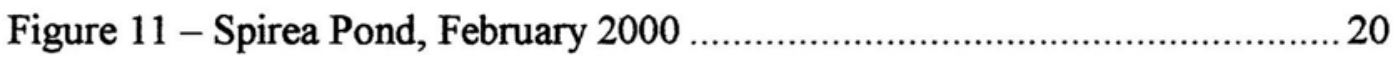

Figure 12 - Vegetation composition and oviposition use per pond of the four

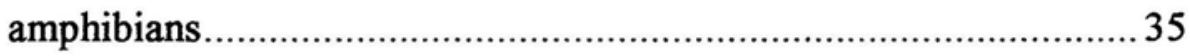

Figure 13 - Amphibian Egg Mass Count Per Pond......................................... 39

Figure 14 - Native versus exotic substrate use for the northern red-legged frog . 42

Figure 15 - Native versus exotic substrate use for the northwestern salamander. 46

Figure 16 - Native versus exotic substrate use for the long-toed salamander ...... 48

Figure 17 - Native versus exotic substrate use in the Pacific treefrog ................ 49

Figure 18 - Oviposition versus cover around pond edges for the northern redlegged frog and northwestern salamander 
Figure 19 - Variation in percent cover around oviposition sites for the northern red-legged frog and northwestern salamander. 60

Figure 20 - Water quality 64 


\section{List of Tables}

Table 1 - Study Pond Characteristics, 2000 17

Table 2 - Other Features of Study Ponds 18

Table 3 - Pond vegetation, Fall 1999 32

Table 4 - Pond Water Temperatures, February-April 2000 39

Table 5 - Amphibian Egg Mass Numbers, 2000 Reproductive Season

Table 6 - Use versus availability of native versus nonnative substrates for each amphibian species, 2000 reproductive season

Table 7 - Variation in oviposition substrate mass, density, and diameter. .52

Table 8 - Comparison of oviposition substrate variation

Table 9 - Use versus availability of specific oviposition substrates for each amphibian species, 2000 reproductive season

Table 10 - RAAU use of substrates ranked by strength and complexity .54

Table 11 - AMGR use of substrates ranked by strength and complexity 54

Table 12 - HYRE use of substrates ranked by strength and complexity 54

Table 13 - AMMA use of substrates ranked by strength and complexity 54

Table 14 - Egg mass distribution versus pond edge cover, 2000 reproductive season .58

Table 15 - Percentage of aquatic vegetation cover around egg masses, 2000 reproductive season

Table 16 - Relationship of number of northern red-legged frogs egg masses and vegetation cover, 2000 reproductive season 
Table 17 - Comparison of water quality variables among pond, February-April 2000 .63 


\section{Introduction}

Numerous recent reports of amphibian declines have increased awareness of the importance of this group and of environmental conditions to which they appear linked. Increased awareness has led to greater scrutiny of the status of amphibians globally (Blaustein and Wake 1990, Blaustein et al. 1994). Commercial harvesting, competition from exotic species, habitat loss, pathogenic fungi, pollution, ultraviolet radiation, and an interaction of one or more of these factors have all been suggested as causal in amphibian declines (Jennings and Hayes 1985; Pechmann et al. 1991; Sjogren 1991; Blaustein et al. 1994, 1995; Corn 1994; Berger et al. 1998, Lawler et al. 1999, Bosch et al. 2001). The factor deemed most important, however, frequently varies depending on the geographic area and amphibian species in question and may sometimes be confounded with several other factors. Careful field experiments and clear hypotheses can help eliminate confusion in determining the causal factors for each species. Studies on the decline of western ranid frog species provide examples of how these factors can be confused (Hayes and Jennings 1986). For instance, recent work suggests that declines of native species in the northwest as a result of apparent competition from introduced bullfrogs (Rana catesbeiana) may in fact be a result of negative impacts of humans on habitats that favor bullfrogs over native species (Kiesecker et al. 2001), an alternative that Hayes and Jennings (1986) originally emphasized as a fertile area for research. 
Habitat loss is the one factor that is consistently touted as an important contributor to the decline of amphibians (Sjogren 1991, Delis 1996, Marsh and Pearman 1997, Kiesecker 1998). Habitat loss can however, vary in degree and form from total loss of a habitat to more subtle changes in hydrology and vegetation. Pond-breeding amphibians often attach eggs to emergent vegetation. One potentially important, but subtle type of habitat change that could affect amphibian reproduction is the introduction of invasive exotic plants. While many studies have examined the effects of invasive exotic plants on the success and distribution of native plants (Macdonald and Frame 1988, Smith 1990, Fernberg and Wehr 1995, Yavitt and Williams 1996, Stohlgren et al. 1999), few have addressed the influence of exotic plants on animals and other non-plant elements in ecosystems (Waring and Tremble 1992, Trammell and Butler 1995, Ramos 1996, Chown 1997, Stromayer 1998). Still fewer studies have identified what specific features of vegetation may be important to amphibians (Wiens 1970, Resetarits and Wilbur 1989, Figiel and Semlitsch 1995, Holomuzki 1995, Richter and Azous 1995, Kiesecker and Blaustein 1997).

Studies on the influence of exotic species on amphibians have frequently focused on animals (Hayes and Jennings 1986, Kiesecker 1998, Lawler et al. 1999). In particular, the influence of exotic plants on amphibians has not been directly studied (Adams 1999). My study was designed to help fill this gap by examining a guild of four pond-breeding amphibians in northwestern Oregon. I 
examined oviposition to determine whether selectivity in oviposition substrate might occur where both native and exotic plants were available. I also examined the not necessarily exclusive alternative hypotheses of whether structural features affecting oviposition substrate strength or cover complexity might affect oviposition site choice.

The four pond-breeding amphibian species that I studied included northwestern salamander (Ambystoma gracile, abbreviated AMGR hereafter in tables and graphs), long-toed salamander (Ambystoma macrodactylum, AMMA), Pacific treefrog (Hyla regilla, HYRE), and northern red-legged frog (Rana aurora aurora, RAAU). Selection of these species was based largely on their abundance at my target study site and their use of oviposition braces that would permit tests of the aforementioned hypotheses. Review of the literature on reproduction and oviposition for these four amphibians revealed substantial data on their breeding habits and development but almost nothing on the factors involved in selection of oviposition sites.

Positioning of egg masses and timing of oviposition as well as the quantity and quality of zygotes are important to survival, and in most amphibians are species specific (Beebee 1996). Factors that can influence placement of eggs and the shape of the egg cluster are predation rate and predator behavior, rate of water flow, desiccation, low temperatures, UV radiation and acidic water (Stebbins and Cohen 1995, Beebee 1996). Only a few studies have looked at the survivorship of 
aquatic eggs to hatching. Licht (1974) found a variation in egg survivorship from $2.6 \%$ in the newt, Triturus vulgaris, to $91 \%$ in Rana aurora aurora. A correlation between embryonic temperature sensitivities and environmental temperature during the breeding season has been found in other studies of anuran eggs (Moore 1939, Licht 1971). Hatching success and larval survival of Rana aurora and Hyla regilla was unaffected by ambient UV radiation, but embryonic and larval life stages of these anurans were sensitive to enhanced UV-b, suggesting potential vulnerability to increases in solar UV-b in the future (Ovaska et al. 1997). Egg mass location, therefore, may influence exposure of embryos to UV-b.

Northern red-legged frog embryos have a thermal tolerance of $4-21^{\circ} \mathrm{C}$ and adults do not oviposit until waters are at least $6-7^{\circ} \mathrm{C}$ (Licht 1971). Licht also found that the embryos could withstand short-term cold exposure as low as $1^{\circ} \mathrm{C}$. Submerging their eggs protects the red-legged frog embryos from thermal extremes. Spawning at night also may allow the embryos to progress to developmental stages that are able to tolerate higher daytime temperatures. Eggs that are in globular masses are better insulated and less likely to freeze (Zweifel 1968, Zweifel 1977).

Attachment of eggs to stems or leaves by ambystomatid salamanders in mid-water also prevents eggs from sinking into the mud on the bottom with a lower oxygen supply (Duellman and Trueb 1994). Other experiments on newts showed that in Triturus and Notophthalmus, the female has a cloacal mechanism for 
detecting oxygen production and eggs are placed only on young leaves with higher oxygen production (Winpenny 1951).

Various studies have also shown that vulnerability of amphibian embryos to predation appears to strongly influence selection of oviposition sites. Resetarits and Wilbur (1989) found that female treefrogs (Hyla chrysoscelis) from the eastern US and southeastern Canada) tended to avoid pond sites where significant threats of predation and intraspecific larval competition existed. Kats and Sih (1992) studied the streamside salamander (Ambystoma barbouri) (eastern US) and found they select egg-laying sites along streams that reduce exposure of the young larvae to predatory fish. Egg-laying sites of larger, presumably more experienced male bullfrogs (Rana catesbeiana) have been found to have significantly lower larval mortality than the sites of smaller males (Howard 1978). Grubb (1972) studied the differential predation of the mosquitofish (Gambusia affinis) on the eggs of seven species of central Texas anurans to ascertain whether permanent water predators may influence breeding site selection. He found differences in the size and texture of the jelly envelopes between permanent and temporary water breeders, with temporary water breeders having smaller eggs and greater attacks by the fish. Differential vulnerability of the eggs to aquatic predators may be a factor that at least contributes to preferences among certain species for temporary pools as breeding sites (Grubb 1972). 
In this research, I first focused on examining the previously unaddressed hypothesis that native amphibians exhibit distinctive patterns of oviposition based on vegetation status (native versus exotic). I then re-examined the oviposition substrate data to test the hypothesis whether the strength of the substrate might be responsible for differences in oviposition. . Lastly, I re-examined the substrate data to determine whether cover, either provided by the oviposition substrate or by egg masses being position close to cover, might influence oviposition. Each of these hypotheses was addressed by testing of a null hypothesis of no difference in oviposition patterns between substrates having different statuses, strengths, or cover characteristics.

Besides simply addressing factors influencing oviposition site selection, this study was intended to provide data to help develop basic recommendations for properly managing habitat that amphibians use for reproduction. In particular, I hoped to gain insights that would allow developing preliminary recommendations on how to address the influence of exotic plants, preferred oviposition substrates, and cover conditions for the amphibian species I studied.

\section{Study Species Natural History}

\section{Northern red-legged frog}

The northern red-legged frog (Rana aurora aurora, Figure 1) is distributed west of the Cascade Range in forests and lowlands from northwestern California to southwestern British Columbia below 1,097 m [3,600 ft] elevation. They breed 
during a relatively cool seasonal interval, typically early February through March, when water temperatures are between $4-10^{\circ} \mathrm{C}$ (Brown 1975). They use still-water habitats, including ponds, lake edges or slow-moving backwaters along streams for reproduction (Nussbaum et al. 1983). Males typically call from under water (Hayes and Miyamoto 1984) and adults move to upland areas with mesic substrates soon after breeding (Storm 1960, Licht 1969).

Northern red-legged frogs have large, relatively loose egg masses that, when fully hydrated, range from the size of a grapefruit to a cantaloupe (600-2,000 eggs, Figure 1) and are typically attached to an emergent vegetation brace (Licht 1969, Licht 1971). Egg masses are usually found in water 0.5-2.0 m deep (Corkran and Thoms 1996). The eggs are black above and white below and lie within a relatively large jelly capsule. During early development, Licht (1971) found that egg mass temperature was significantly higher (by about $3.6^{\circ} \mathrm{C}$ ) than that of the surrounding water.

Temperature is the major factor influencing developmental rate of egg masses (Storm 1960). He reported that the time from laying to hatching averaged 35-49 days. During development, a growth of green alga often develops within the capsule; oxygen production by this alga tends to promote floating of egg masses as the embryos near hatching (Storm 1960). Recently hatched larvae will remain close to the egg mass for a few days either resting on the bottom or hanging on to plants or debris with their adhesive (chin) glands (Brown 1975). 


\section{Northwestern salamander}

The northwestern salamander (Ambystoma gracile, Figure 2) is a species similar to northern red-legged frog in it ranges largely west of the Cascades (Nussbaum et al. 1983). However, it occurs further north into British Columbia (Green and Campbell 1984).

They live in moist forests or partly wooded areas from sea level up to 2,000 $\mathrm{m}[6,550 \mathrm{ft}]$ and breed in ponds, lakes, and slow backwater areas of streams. The breeding season varies depending on altitude and latitude. In the southern coastal parts of its range, the northwestern salamander may breed as early as late January or February but in northern high-elevation lakes which may have ice until July, breeding may begin as late as August (Nussbaum et al. 1983). Males are reported to arrive at the breeding pond first and remain at the pond until the end of the breeding interval. In contrast, females leave soon after depositing their eggs. Length of the breeding season ranges from less than one week to nearly two months depending on the onset of warm spring weather and also, perhaps the proportion of terrestrial versus paedomorphic adults (reproductive adults that retain external larval features) in the breeding population (Eagleson 1976). Egg masses are laid in water and typically attached to relatively thin stems or sticks $(0.4-0.8 \mathrm{~cm}$ in diameter), $0.5-2.0 \mathrm{~m}$ below the water surface. The egg mass has a very firm jelly with a smooth or wavy surface due to an extra layer of jelly around the entire mass. 
The size of the mass ranges from that of a small orange to a small grapefruit, and contains 40 to 270 tan and cream-colored eggs (Figure 2).

The embryonic period for northwestern salamanders is 30 to 60 days depending on egg size and temperature (Brown 1976). Slower embryonic development within A. gracile egg masses allows enough time for significant intracapsular algal growth. This pattern of algal growth appears to benefit embryonic survival (Marco and Blaustein 2000). Hatchlings are ca. 14-15 mm total length (TL). Larvae usually do not metamorphose until the second year when they are about $50 \mathrm{~mm}$ snout-vent length (SVL) (Licht 1975). Larvae can also become paedogenetic in the second or third year (Eagleson 1976). The development of paedomorphic individuals does not seem to be related to food abundance but habitat stability (aquatic habitat permanence) in this facultatively paedomorphic species (Licht 1992). The larvae feed on many diverse aquatic invertebrates but are highly dependent on microcrustacean zooplankters at smaller body sizes (Licht 1975). Aquatic beetle larvae and fish (e.g., trout) are among the main predators of larvae (Tyler et al. 1998).

\section{Pacific treefrog}

The Pacific treefrog (Hyla regilla, Figure 3) is the most common, widespread frog in western North America (and the Pacific Northwest), occurring wherever still-water provides reproductive sites, ranging from sea level to high 
elevations (Nussbaum et al. 1983). The species is terrestrial during the nonbreeding season. Pacific treefrogs will utilize almost any small, stillwater body, which can place them at risk when small ponds dry too quickly (Nussbaum et al. 1983). Pacific treefrogs move to aquatic breeding sites from November (coastal) to July (mountains) after warm $\left(>10^{\circ} \mathrm{C}\right)$ winter rains (Nussbaum et al. 1983). Males "chorus" mostly at night once in the water and tend to call in groups where one is the leader (Awbrey 1978). Females are attracted to the loud choruses and often select the group leader as a mate (Perrill 1984). Males use short single-note calls, which appear to function largely to space the males within the pond, but have a specific advertisement call that attracts females (Brenowitz and Rose 1999).

The eggs are laid in packets of 9-70 eggs (Figure 3) attached to submerged vegetation or laid on bottom of shallow pools (Corkran and Thoms 1996). Individual eggs are relatively small (about $0.7-1.3 \mathrm{~mm}$ in diameter), brown above and a dirty yellow below with two jelly envelopes (Nussbaum et al. 1983). Eggs hatch in three to five weeks in western Oregon. Tadpoles are about 6-8 mm TL at hatching (Corkran and Thoms 1996).

\section{Long-toed Salamander}

The long-toed salamander (Ambystoma macrodactylum, Figure 4) is the smallest member of the genus Ambystoma in the Pacific Northwest. They use a wide variety of habitat types including semi-arid sagebrush deserts, dry woodlands, 
humid forests, alpine meadows, and other intermediate habitats from sea level to ca. $3000 \mathrm{~m}[9,800 \mathrm{ft}]$ elevation (Nussbaum et al. 1983). Terrestrial individuals remain mainly below ground during the extreme weather conditions (i.e., freezing or hot and dry), and then emerge in early spring to breed near ponds and lakes. The breeding season varies, depending on the microclimate of the habitat (Howard and Wallace 1985). In mild coastal climates, like the Willamette Valley, the breeding season starts as early as October and may last until April. In areas with harsher climates, the breeding migration will not start until late February to early April, depending on the local conditions. The breeding season can be as short as three weeks (Verrell and Pelton 1996).

Egg laying methods vary from single eggs attached to vegetation in shallow water up to packets of 5-100 eggs (Figure 4) in shallow to deep water, attached to vegetation or under the surface of a $\log$ (Leonard and Richter 1994). Eggs are sometimes placed loosely on the bottom. The size of the individual eggs ranges from 2.0 to $2.5 \mathrm{~mm}$ in diameter and the eggs are dark (black or brown) on top and white on the bottom. Clutch size of an individual female ranges from $85-411$ eggs and increases with female body size (Howard and Wallace 1985). Typically, larvae reach maturity in one season, but in some high elevation habitats they may take two seasons (Fukumoto and Herrero 1998). 


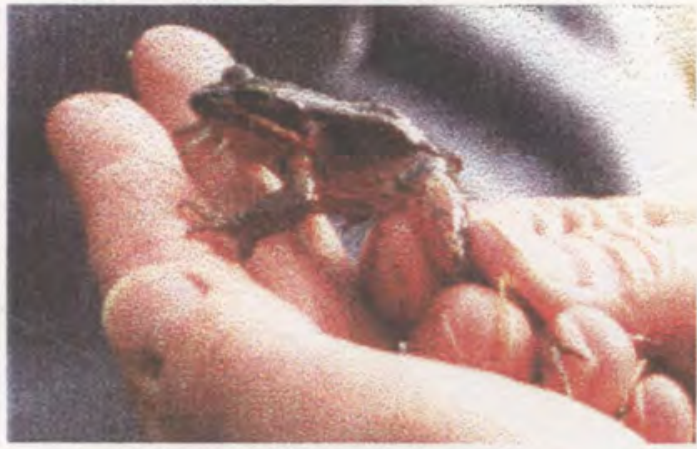

Figure 1 - Northern red-legged frog (Photo: C. M. Callison 2000)

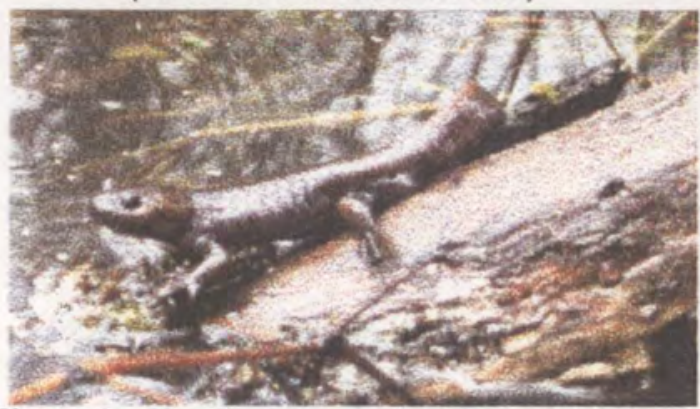

Figure 2 - Northwestern salamander (Photo: C. M. Callison 1999)

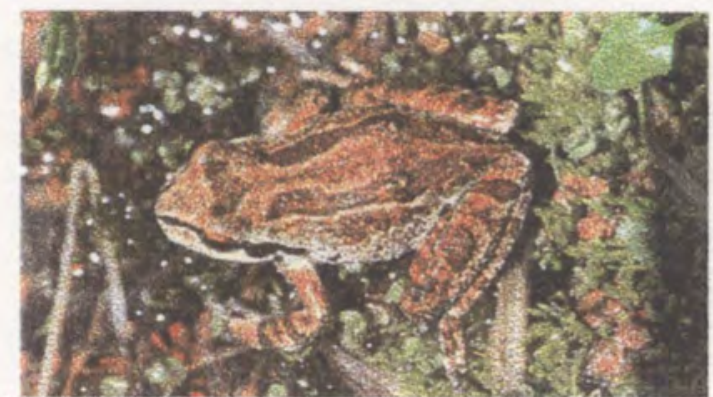

Figure 3 - Pacific treefrog

(Photo: C.C. Corkran)

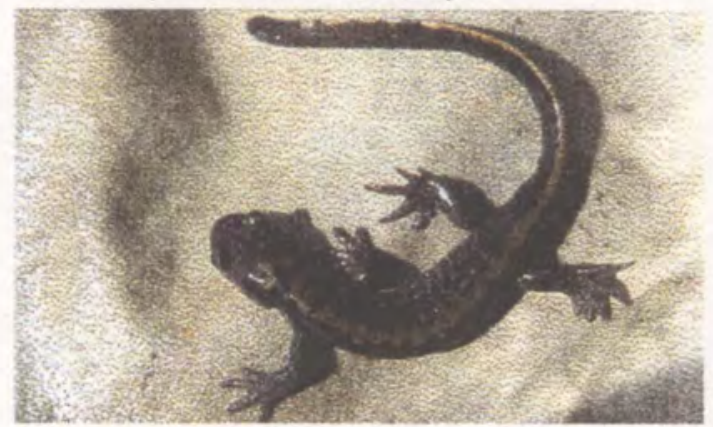

Figure 4 - Long-toed salamander

(Photo: C.C. Corkran)

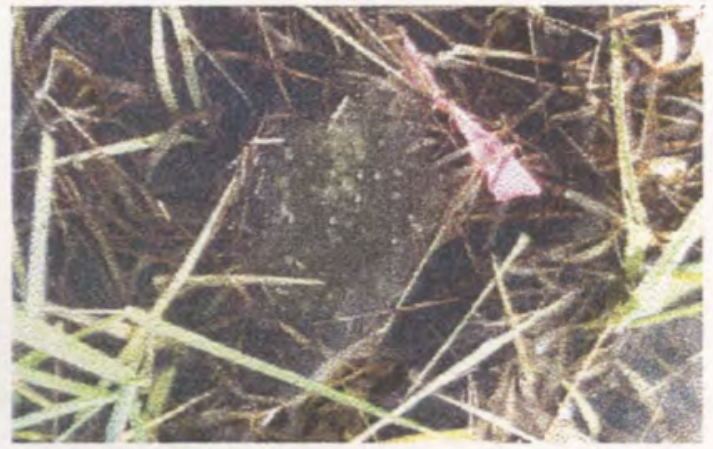

Egg mass of northern red-legged frog (Photo: C. M. Callison 2000)

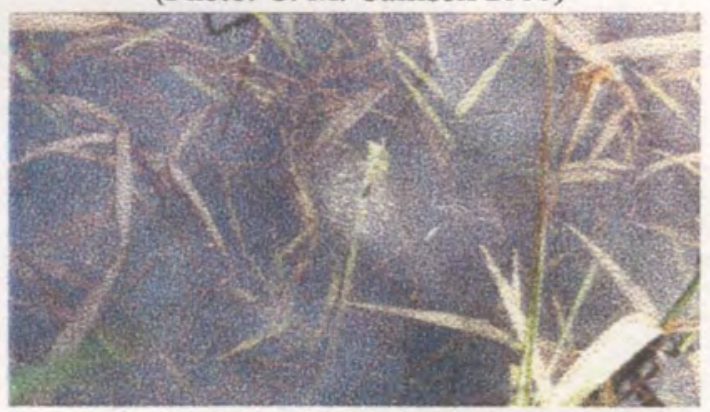

Egg mass of northwestern salamander (Photo: C. M. Callison 2000)

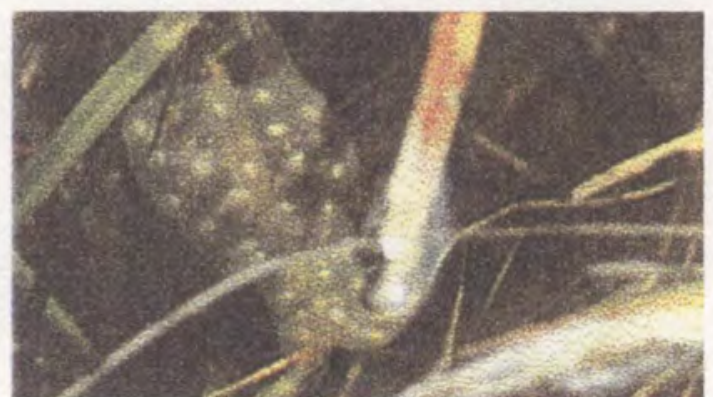

Egg mass of Pacific treefrog (Photo: C.C. Corkran)

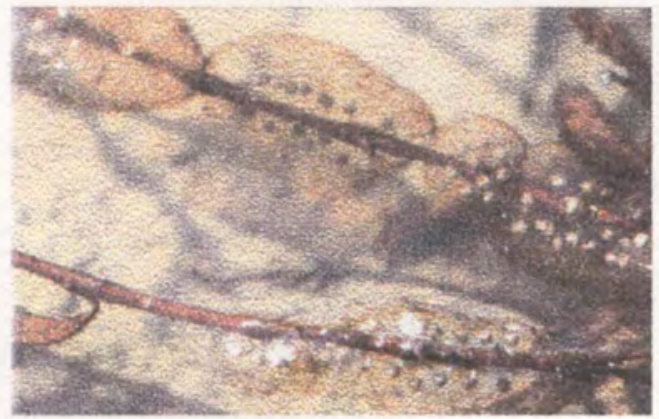

Egg mass of long-toed salamander (Photo: C.C. Corkran) 


\section{Materials and Methods}

\section{Study Area}

I conducted this study at Burlington Bottoms, a riverine site along the Multnomah Channel near the confluence of the Columbia and Willamette Rivers. Under the management of the Oregon Department of Fish and Wildlife (ODFW), Burlington Bottoms is a mitigation site for Bonneville Power Administration (BPA) dam-associated modifications of the Lower Columbia River region. This site consisted of a complex array of ponds, lakes, and sloughs, intermixed with lowland riparian forest (Appendix A).

Many factors, human-linked and otherwise, have influenced the hydrology of this site. Annual spring freshets (high water events) of the Columbia and Willamette Rivers regularly inundate parts of the site. Further, a series of culverts carry runoff from uplands and nearby Highway 30 to the west. Since the site is now a protected wetland, the main factors affecting onsite hydrology are freshwater inflows from the elevated landscape across the highway, and the tidal influence of the Columbia. In addition, beaver activity onsite (and perhaps, to some degree, offsite) modulates freshwater inflows. Some of the topography and water features are the result of excavation and fill. The elevation of the study ponds, which are located on the northern portion of Burlington Bottoms, are all below $4 \mathrm{~m} \mathrm{[12 \textrm {ft } ]}$ above mean sea level (see Pacific 1993; specifically maps in hydrology report for Burlington Bottoms). Soils are Rafton and Sauvie silt loams typical of lowland 
riverine areas subjected to repeated flooding. Both soils are considered poorly drained and poorly suited to most human uses but can be valuable wildlife habitat. Seasonal air temperatures vary from highs above $18^{\circ} \mathrm{C}\left(65^{\circ} \mathrm{F}\right)$ in summer to lows reaching $1.7^{\circ} \mathrm{C}\left(35^{\circ} \mathrm{F}\right)$ in winter. Freezing is infrequent, usually occurring in the interval November-February. The mean annual precipitation for the area averages $94 \mathrm{~cm}$ (37 in) with most precipitation falling as rain from November through March. Wind is seasonally largely bidirectional, coming primarily from the NW during winter and the SE during summer. Low levels of wind (Beaufort scale values 1-4) are frequent, but strong wind is rare. The wind is calmest between the spring and fall months. Weather data were extracted from summaries of the interval 1971-2000 for the Portland International Airport Data Station (National Climatic Data Center Website: http://www4.ncdc.noaa.gov/).

Human activity over the last 60 years has markedly influenced this site. In particular, maintenance of railroad equipment, livestock grazing, and building of shantytown housing and access roads has occurred. From 1936 through the early 1960s, a log depot and maintenance facility existed in the southern portion of the area. Cattle grazing occurred from 1961 through 1991 (Pacific 1993). Another important change during this century has been the alteration of seasonal hydrology, which was a consequence of the dam-building era on the Columbia River between the 1930s and 1970s. The most prominent alteration of seasonal hydrology has been the decrease in frequency of large magnitude of spring freshets, which have 
both decreased levels of annual inundation and the load of water-borne sediments that are deposited seasonally. Both are important in the pattern of renewal of offchannel riverine habitats (e.g., oxbows, sloughs), of which my study ponds are all a part.

\section{Study Sites}

I selected seven study ponds based on their known amphibian use and their different proportions of native versus exotic aquatic vegetation. I selected the latter to ensure a range of variation in native versus exotic vegetation in order to determine whether that variation might affect the pattern of use by native amphibians. Monitoring, mostly for amphibian egg masses, had been done on these ponds since 1996. This study complemented and augmented previous surveys through examination of microhabitat characteristics of egg mass locations. Previous surveys lacked opportunity to examine microhabitat characteristics because of time and funding constraints.

During the droughty interval when I did my fieldwork (1999-2000), all seven ponds were largely individual units, and except for Kidney, all ultimately dried in 2000 (Table 1). Seasonal freshets in previous years have inundated Burlington Bottoms so it was not possible to distinguish individual ponds during high water (S. Beilke, M. Hayes, pers. comm.), but not in 2000. During 2000 high water conditions, which peaked in February, aquatic connections to other water 
bodies were restricted to beaver channels between each of three of the ponds and an adjacent permanent, fish-occupied slough (Table 2; see also Appendix K). Some activity I saw in these ponds (e.g., great blue heron [Ardea herodias] in Kidney Pond) may result from these aquatic connections, allowing fish access. Besides the above-noted beaver channels, old or fresh beaver sign as the result of bark removal, chewed stumps, felled trees, and terrestrial pathways were recorded at five of the seven ponds. Most beaver sign was old; most chewed stumps or felled trees were Pacific willow (Salix lucida var. lasiandra); and Pancreas Pond, with its array of old willow stumps, had most of the beaver sign. Evidence of grazing (e.g., clipped herbaceous vegetation) was other animal sign that was prominent during study of these ponds. Some grazing occurred in all ponds, but it was dramatic in Kidney Pond, in which I made regular observations of at least five pairs of mallards, and some sign of muskrat and nutria was seen. Muskrat activity was also frequent in Pancreas Pond. 
Table 1 - Study Pond Characteristics, 2000

\begin{tabular}{|c|c|c|c|c|c|}
\hline \multirow{2}{*}{ Pond } & \multicolumn{2}{|c|}{ Maxima $^{a}$} & \multicolumn{2}{|c|}{ Hydroperiod } & \multirow{2}{*}{ Dominant Vegetation } \\
\hline & $\begin{array}{c}\text { Surface } \\
\text { Area } \\
\left(\mathrm{m}^{2}\right)\end{array}$ & $\begin{array}{l}\text { Depth } \\
\text { (m) }\end{array}$ & Status & Dry by & \\
\hline Butterfly & $482^{b}$ & 0.5 & Temporary & Late June & Reed canarygrass \\
\hline Kidney & 2,940 & 0.4 & Permanent & - & Wapato \\
\hline Muskrat & 525 & 0.6 & Temporary & July & $\begin{array}{c}\text { Reed canarygrass; Water } \\
\text { pepper }\end{array}$ \\
\hline Oak & 74,400 & 0.8 & Temporary & Late August & $\begin{array}{c}\text { Reed canarygrass; Water } \\
\text { pepper }\end{array}$ \\
\hline Pancreas & 1,550 & 0.6 & Temporary & Late June & $\begin{array}{l}\text { Water pepper; Reed } \\
\text { canarygrass }\end{array}$ \\
\hline Sedge & 2,790 & 0.4 & Temporary & June & Reed canarygrass \\
\hline Spirea & 336 & 0.5 & Temporary & June & Reed canarygrass \\
\hline
\end{tabular}

${ }^{\text {a }}$ Surface area and depth maxima occurred during February 2000. Surface area was estimated using GIS and pond maps (see Methods Section on Mapping, step 4). Depth was measured using a gauge placed near the lowest elevation point in each pond.

${ }^{b}$ Butterfly was a bi-lobed pond; the surface area is indicated for the north lobe, which was the only part of this pond with significant water during the amphibian reproductive season in 2000.

Study ponds varied over two orders of magnitude in their maximum surface area in 2000 , but their maximum depth varied only two-fold and even the deepest pond (Oak) was relatively shallow (Table 1). Although herbaceous vegetation diversity partly guided pond selection, every pond had at least some reed canarygrass, an exotic that dominates much of the lowland riverine landscape in this region. A native aquatic, water pepper (Polygonum hydropiperoides) was a prominent element in three ponds, and another native aquatic, wapato, was dominant in Kidney Pond. Details of the herbaceous species composition of each of the seven ponds are provided in Table 3 . All seven ponds lie in a mosaic of 
bottomland riverine forest, the canopy of which was located at varying distances

from the ponds (Table 2). Forest composition varied, but was largely dominated by a composite of black cottonwood (Populus balsamifera var. trichocarpa), Oregon ash (Fraximus latifolia), and Pacific willow.

Table 2 - Other Features of Study Ponds

\begin{tabular}{|c|c|c|c|}
\hline Pond & Structural & Vegetation & $\begin{array}{l}\text { Illustrations } \\
\text { (Figure \#) }\end{array}$ \\
\hline Butterfly & Two pond lobes & $\begin{array}{l}\text { No tree or shrub vegetation on edge; } \\
\text { nearest trees and shrubs }>20 \mathrm{~m} \text { distant }\end{array}$ & 5 \\
\hline Kidney & $\begin{array}{l}\text { Beaver channel } \\
\text { connection to slough; } \\
\text { extremely silty }\end{array}$ & $\begin{array}{l}\text { Woody vegetation on three sides; } \\
\text { herbaceous vegetation heavily grazed } \\
\text { and seasonal dieback }\end{array}$ & 6 \\
\hline Muskrat & & Ash and willow surrounded & 7 \\
\hline Oak & $\begin{array}{l}\text { Beaver channel } \\
\text { connection to slough }\end{array}$ & $\begin{array}{l}\text { Northwest margin with ash and willow; } \\
\text { some dead or live willow in pond; } \\
\text { hardhack and reed canarygrass on } \\
\text { south/west margins }\end{array}$ & 8 \\
\hline Pancreas & $\begin{array}{l}\text { Beaver channel } \\
\text { connection to slough; } \\
\text { many stumps }\end{array}$ & Limited marginal woody vegetation & 9 \\
\hline Sedge & $\begin{array}{l}\text { Near slough, but no } \\
\text { aquatic connection }\end{array}$ & North margin with ash and willow & 10 \\
\hline Spirea & & $\begin{array}{l}\text { Lone willow in mid-pond; hardhack } \\
\text { margin }\end{array}$ & 11 \\
\hline
\end{tabular}

${ }^{a}$ Nearest tree and shrub vegetation was $>20 \mathrm{~m}$ away. 


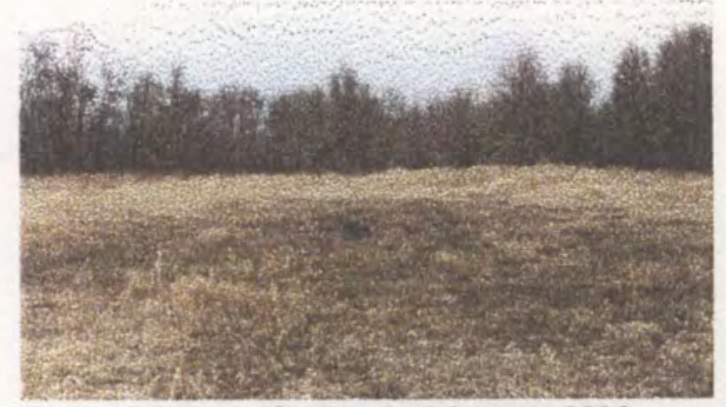

\section{Figure 5 - Butterfly Pond, February 2000}

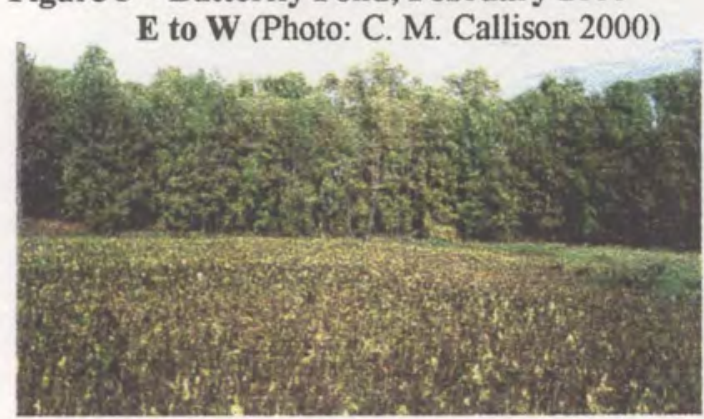

Figure 6 - Kidney Pond, September 1999

E to W (Photo: C. M. Callison 1999)

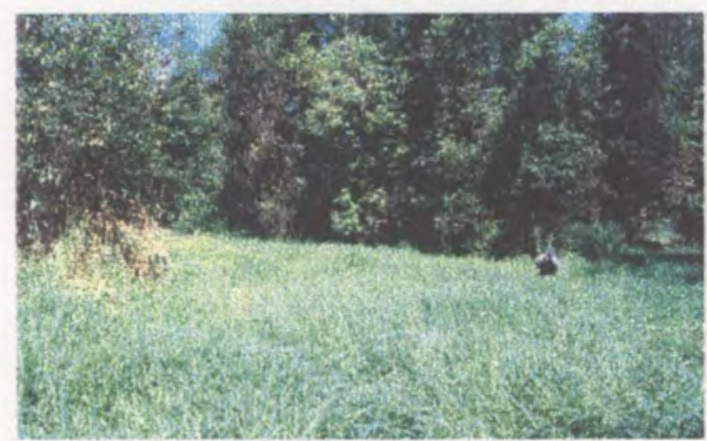

Figure 7 - Muskrat Pond, September 1999

SW to NW (Photo: C. M. Callison 1999)

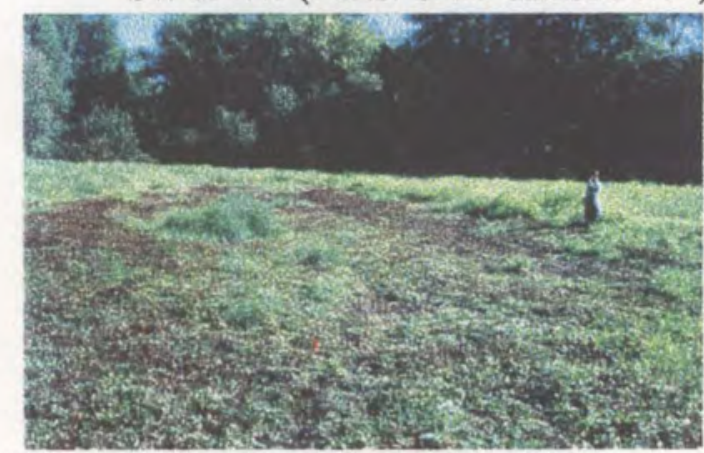

Figure 8 - Oak Pond, September 1999

West lobe to NE (Photo: C. M. Callison 1999)

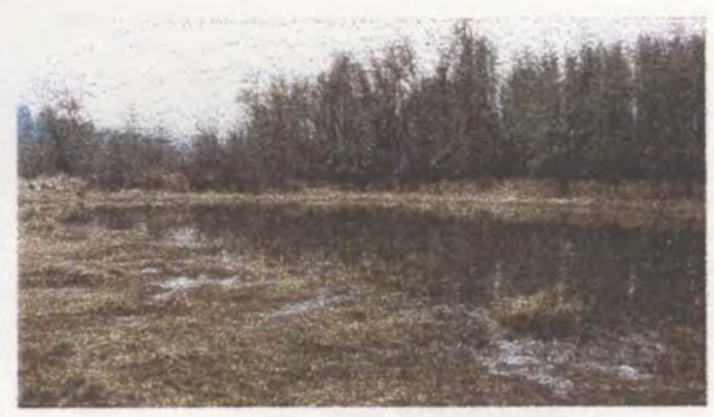

Kidney Pond, February 2000

SE to SW (Photo: C. M. Callison 2000)

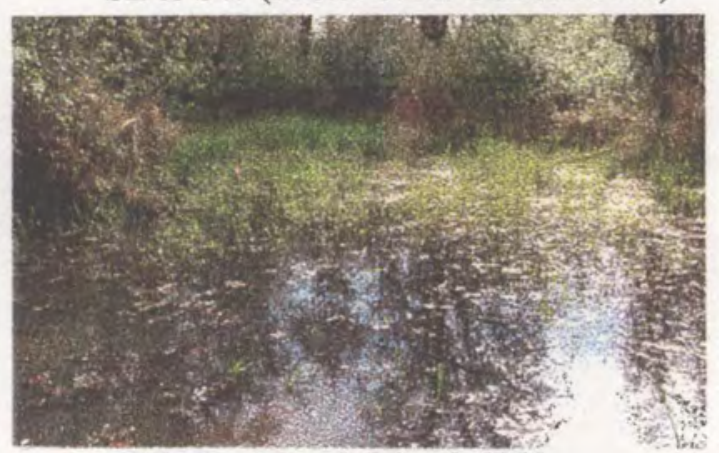

Muskrat Pond, March 2000

SE to SW (Photo: C. M. Callison 2000)

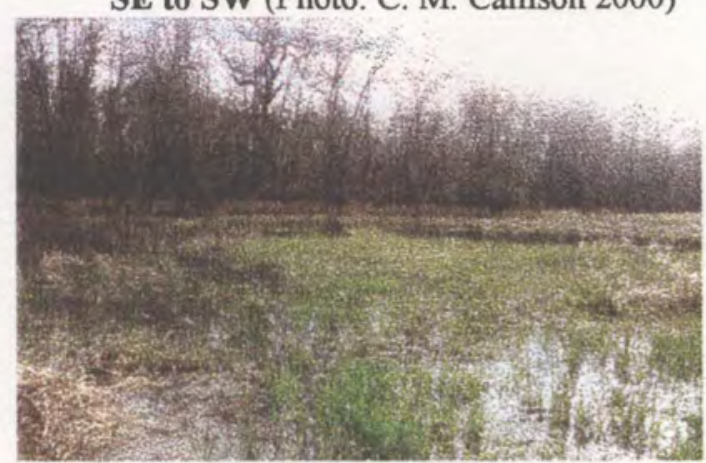

Oak Pond, March 2000

NW lobe to SE (Photo: C. M. Callison 2000) 


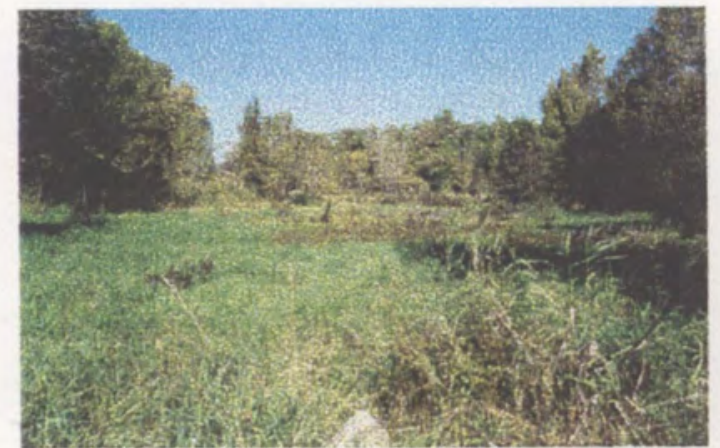

Figure 9 - Pancreas Pond, September 1999 NE to SE (Photo: C. M. Callison 1999)

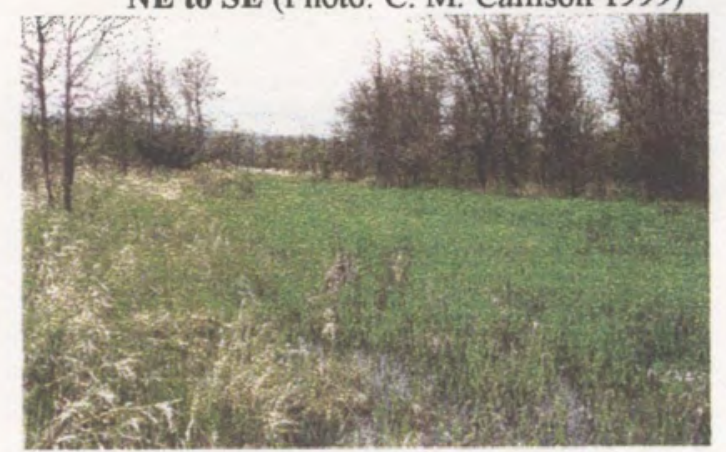

Figure 10 - Sedge Pond, February 2000

SE to NW (Photo: C. M. Callison 2000)

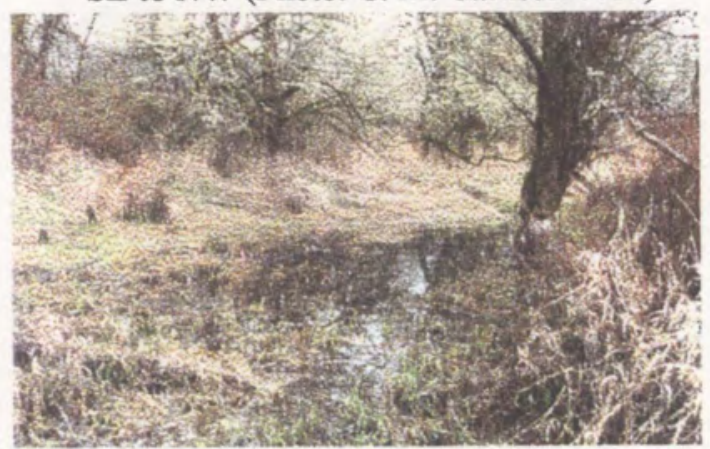

Figure 11 - Spirea Pond, February 2000

SW to NE (Photo: C. M. Callison 2000)

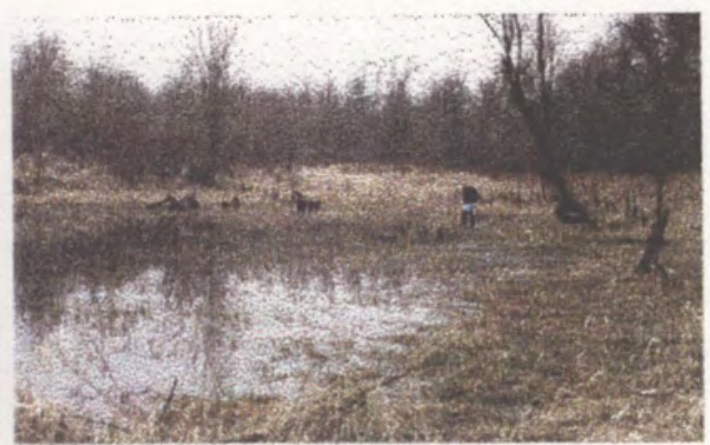

Pancreas Pond, February 2000

NE to SE (Photo: C. M. Callison 2000) 


\section{Vegetation Surveys}

\section{Within Ponds}

I surveyed the vegetation in each pond in the interval 10 September to 1 October 1999, when the ponds were dry (Appendix B). Parallel line transects with points $3.0 \mathrm{~m}$ apart (Sutherland 1996) were used to determine vegetation species present in each pond. The first point on each transect was at the start of the transect and plant species within $30 \mathrm{~cm}$ circle surrounding that point were recorded along with the status of each species (exotic or native). The direction and starting locations of transects varied according to the size and shape of the pond in order to cover the entire pond area (Appendix C). The vegetation transects were not redone during the winter to minimize disturbance of the egg masses by entering the ponds as little as possible. However, I recorded changes in pond vegetation that might alter the availability of oviposition braces. Only two ponds experienced visible change in vegetation during the winter; the vegetation composition in these ponds was re-assessed to reflect this change. As only the north lobe of Butterfly retained significant water during the amphibian- breeding season in 2000 and it was the only area of Butterfly used by amphibians, I redid the vegetation analysis to show only the north lobe.

\section{Around Ponds}

I scored marginal vegetation around the pond (within ca. $2 \mathrm{~m}$ of the shoreline) into three structural categories (herbaceous, shrub, and tree) at single 
points $3 \mathrm{~m}$ apart. Only the species of trees and shrubs were recorded during these surveys. Surveys were conducted in March 2000 during the mapping of pond water levels (Appendix D).

\section{Animal Surveys}

\section{Amphibian Egg Masses}

I surveyed egg masses in the interval 19 January 2000 to 31 March 2000.

The dates and survey effort for each pond is shown in Appendix E. I took a series of measurements and observations on the egg masses or packets of the four different amphibians the first day they were discovered. Egg masses of northern red-legged frog and northwestern salamander were sampled in all seven ponds. As their numbers were large, I sub-sampled the egg packets of long-toed salamander and Pacific treefrog only in Muskrat and Butterfly Ponds. The survey protocol and sheet for collection of egg mass or packet data are shown in Appendix F and G. These were developed from several established protocols for this site and others used in the Northwest (Olson et al. 1997). I located the egg masses by doing visual systematic surveys starting at one end of the pond and covering the entire pond. Once an egg mass was located, I flagged it and assigned it a number (each mass numbered consecutively by species as it was located). I recorded each egg mass, its height in the water column, its distance from the nearest shoreline, and measure the percentage of vegetation cover with a $15-\mathrm{cm}$ radius circle around the egg mass. These variables were taken to help characterize the oviposition substrate structure, 
amphibian egg mass or packet position, and potential differences within and among ponds.

The vegetation substrates on which the egg masses or packets were deposited were also scored for three variables: exotic versus native; the oviposition substrate species represented; and a diameter of the stem or leaf of the substrate. I also took samples of the plant that were used as oviposition substrates back to the laboratory to be dried and weighed. Density was determined by calculating a cylindrical volume from a set length $(10 \mathrm{~cm})$ and measured diameter. These samples were used to determine the strength index of the substrates. The various masses, diameters and densities for each species were first compared to determine if they were significantly different from one another. They were then ranked in each measurement category from largest to smallest. These rankings were then totaled for each species to determine an overall ranking that was used as the index of strength.

I selected Muskrat and Butterfly Ponds to obtain a representative sample of Pacific treefrog and long-toed salamander egg packets based on the favorable habitat characteristics of these ponds for these two species. When surveying these two ponds, as many egg packets were marked as three people could find walking in the same direction spaced $3 \mathrm{~m}$ apart. The ponds were divided into $10 \mathrm{~m}^{2}$ quadrats covering the entire pond area, and the estimated number of egg packets in each quadrat was totaled for each species. 
A subsample of 25 egg packets from each of the Pacific treefrog and the long-toed salamander was taken in each of Muskrat and Butterfly Ponds. In order to ensure that the sampled packets in each pond were representative, I first calculated the percentage of each species per quadrat from the total estimated number of egg packets determined from initial walk-through. This percentage was used to estimate the number packets (out of 25) that would be selected from each quadrat. If the sampled number was less than one, I added one to a neighboring quadrat. A north-south transect line ran through the center of each quadrat. I randomly selected points along the transect and measured the egg mass nearest each point in any direction. If two egg masses were the same distance from the randomly selected point, or if two egg masses were one on top of the other, both were measured.

\section{Fish Surveys}

Fish species composition was determined to understand whether fish presence might influence egg mass location or pond choice. Fish surveys were conducted from the 2 February to the 28 April 2001. The dates and times each pond was sampled are shown in Appendix H. I sampled ponds with minnow traps $(1 / 4$ in mesh $[6 \mathrm{~mm}]$ with 2 in $[5.1 \mathrm{~cm}]$ openings) to determine the presence and species composition of fish in the ponds. I placed unbaited traps at three random locations in each pond for a 24-hour sampling interval. Because I had few traps, I could not sample all ponds simultaneously; so I sampled two ponds per night with 
three traps each. Butterfly Pond was not sampled for fish due to its high visibility in the water column, small size, and its low water levels prevented effective use of minnow traps. In addition to trapping, I recorded any visual observations of fish in the ponds.

\section{Invertebrate Sampling}

Six out of seven of the ponds were sampled for invertebrates. Spirea Pond was not sampled because it dried up before the survey could be conducted.

Butterfly and Muskrat Ponds were sampled on 27 March 2000. I sampled Kidney, Oak, Pancreas, and Sedge Ponds on 4 April 2000. Invertebrates were sampled using a $900-\mu \mathrm{m}$ mesh sweep net. Six samples were taken in each pond (three in dense emergent vegetation, three in open water) (Sutherland 1996). Three random locations in each area (vegetated or open water) were selected from a transect through the center of the area. The direction of each transect in each pond is shown in Appendix C. Each sample was taken by doing three sweeps moving back and forth through the entire water column to standardize sampling. After a sample was collected in the net, its contents were emptied into a plastic tub. The net was then rinsed twice with two $900-\mathrm{ml}$ containers of water. Contents of each sample were placed into labeled plastic bags, preserved in $70 \%$ ethanol, and brought back to the laboratory for identification and quantification. Fish and tadpoles were counted and released prior to putting the samples in plastic bags. 


\section{Water Quality Measurements}

For each pond, repeated measurements of water temperature, dissolved oxygen, $\mathrm{pH}$, and turbidity were taken to determine potential differences within and among the ponds. These measurements were used to determine whether oviposition patterns might be more closely tied to a simple physical difference within or among the ponds than to the focal hypotheses being tested.

I used a $\mathrm{H}_{2} \mathrm{O}^{\circledR}$ Water Quality Multiprobe [Hydrolab Corporation - software v2.2 1995] to gather all water quality measurements. All ponds except Spirea and Butterfly (declining water levels prevented me from obtaining measurements as the ponds approached drying) were sampled on three different days (late February, early April, and late April) at about the same time of day (within 2 hours) to avoid diel confounds. I measured water depth, temperature, $\mathrm{pH}$, dissolved oxygen [DO], and turbidity at 10 locations throughout the pond. The ten measurements were taken at 5-7 minute intervals and spaced evenly around the pond. I took each of the three days' measurements at the same locations within the ponds. The logistics of transporting the Hydrolab around to all the selected ponds proved to be the most difficult part in determining the time of day to sample. Evaluation of turbidity was difficult in Kidney pond because my movements easily disturbed its soft substrate. To minimize this problem, I took turbidity readings after standing in one place for 5 minutes and then recorded for 5 more minutes. 
One HOBO data logger was also placed in each pond at the beginning of the oviposition period (4 February 2000) to record water temperatures continuously. Each data logger was placed in the deepest part of the pond and recorded hourly water temperatures. Temperatures were recorded until 29 May 2000.

\section{Mapping}

I mapped each pond's vegetation in order to evaluate the cover hypothesis. The first step in mapping was to place permanent stakes at the edges of the pond that were used as reference points from which the egg mass locations and pond margins were measured. Some of these were also used as starting points for vegetation transects. I labeled each stake according to its location around the pond to the nearest compass or joint direction, sometimes using pond features as part of the description (i.e. NE, SE, NW Lobe NE corner, etc.) The boundary of typical full pool and the location of the egg masses within the pond were originally measured in polar coordinates (radial distance and angle from a base point). Later, I re-measured the reference and perimeter boundary points with a Trimble GeoExplorer II GPS unit. Ultimately, I used only the GPS points, but I include the steps for each method for comparison. Measurements were obtained as follows: 
1. I measured a series of points around the pond to obtain the full pool boundary. For each point, one person (A) would stand at a stake with a compass and the end of a tape measure. Another person (B) would walk to the point to be measured with the other end of a tape measure, and I recorded the distance and the degrees off North from the stake to that point. Points were taken at least every $3 \mathrm{~m}(10 \mathrm{ft})$, but if unique features existed, such as trees or stumps along the pond margin, they were also measured.

2. The polar coordinates for each egg mass were measured from a pole no more than $30 \mathrm{~m}(100 \mathrm{ft})$ away, using two people in the same manner as the boundary measurements.

3. Boundary and egg mass measurements were taken no more than $30 \mathrm{~m}$ $(100 \mathrm{ft})$ from any given pole in order to reduce error in compass readings. Once the whole pond was measured, each point had to be recalculated using geometric formula so that every point and egg mass had a bearing and distance from one reference point.

4. The last step was to measure the poles and boundaries using a GPS receiver (Trimble GeoExplorer II). The accuracy of this unit was within $1 \mathrm{~m}$ after differential correction. The GPS data was used to help create GIS spatial data layers of the ponds (Appendices $\mathrm{C}$ and $\mathrm{K}$ ). The bearing and distance data, along with the GPS data, were compiled with an aerial 
photograph to create GIS "shape file" polygons of the ponds. The locations of egg masses were also geocoded as coordinate points and so could be mapped in relation to their location in each pond. I also calculated the surface area of each pond with these data. I then converted my measurements of egg mass locations to Universal Transverse Mercator (UTM) coordinates using a coordinate geography extension tool in the ESRI Arcview 3.2 GIS program.

\section{Analysis}

I tested for selection/avoidance of native and nonnative plant species for oviposition using data from all species. To perform the tests, I grouped the oviposition substrates into native or nonnative and compared them to the percentage of either native or nonnative substrates available in each pond. Substrate availability was based on the percentage of the fall vegetation comprised of native and exotic species (Table 3). Expected and observed use was compared using Chi-square tests. I used a rejection criterion of $P \leq 0.05$ for all tests performed. Species having fewer than 10 egg masses per pond were not analyzed.

I then examined substrate use in relation to relative substrate strength. After doing the Analysis of Variance (ANOVA) to determine if each species was significantly different for each measurement type, the species were ranked highest to lowest for each measurement. For example, if Pacific willow had the highest 
density it would be ranked 1 , the next highest would be a 2 , etc. The rankings from each measurement type were then totaled to give an overall relative strength index ranking for each species. The higher the rank, the stronger they were considered to be.

The next step in evaluating the substrate strength hypothesis was to compare each individual species used for oviposition to all the other species available in the pond using a Chi-square test to determine if that species was used significantly more often than would be expected from its percent availability. I then compared this to the strength index to see if the brace species used were stronger than the brace species available.

Lastly, I addressed the cover hypothesis, which I tested in several ways. First, I compared the vegetation cover around the pond to the egg mass locations in the pond. After I created polygons of the ponds and converted the egg mass locations to points within those polygons, I divided the edge of the polygon into sections according to their vegetation type (assigned from field notes). Each pond was analyzed using a topographical analysis (Near command) from ArcInfo (ESRI Corp) software that measured the nearest vegetation edge type to each egg mass. The total percentage of each vegetation type per pond was determined from these data. The final step was to compare the percent vegetation cover types available around the pond margin to the percentage of egg masses found nearest each using a Chi-square analysis. 
I performed a correlation analysis of the vegetation within and around the pond margin only for the northern red-legged frog because northwestern salamander was represented in too few ponds. Numbers of red-legged frog egg masses was compared to the percent of vegetation in each of the three cover types (tree, shrub, herbaceous).

Distributions of the percentages of cover estimates taken around egg masses were compared between the northern red-legged frog and northwestern salamander egg masses.

Vegetation used versus available for oviposition was compared using a ranking of structural complexity with a Chi-square analysis for northern red-legged frogs and northwestern salamanders. 
Table 3 - Pond vegetation, Fall 1999

Plant species codes are in Appendix $\mathbf{H}$.

\begin{tabular}{|c|c|c|c|c|c|c|c|c|}
\hline \multirow{2}{*}{$\begin{array}{l}\text { Plant } \\
\text { Species }\end{array}$} & \multirow{2}{*}{ Status } & \multicolumn{7}{|c|}{ Percentage of Total Points Sampled Fall 1999} \\
\hline & & Butterfly & Kidney & $\begin{array}{c}\text { Muskra } \\
t\end{array}$ & Oak & Pancreas & Sedge & Spirea \\
\hline BICE & $\mathrm{N}$ & 0.0 & 0.5 & 0.0 & 7.7 & 0.0 & 0.0 & 0.0 \\
\hline CAAP & $\mathrm{N}$ & 0.0 & 0.0 & 0.0 & 2.2 & 1.5 & 3.9 & 0.0 \\
\hline CAOB & $\mathrm{N}$ & 41.3 & 0.0 & 0.0 & 0.0 & 2.3 & 1.4 & 27.7 \\
\hline ELAC & $\mathrm{N}$ & 2.2 & 1.0 & 0.0 & 0.0 & 0.0 & 0.0 & 0.0 \\
\hline ELOV & $\mathrm{N}$ & 0.0 & 4.5 & 0.0 & 3.7 & 0.0 & 1.4 & 0.0 \\
\hline ELPA & $\mathrm{N}$ & 3.9 & 2.0 & 0.0 & 0.0 & 4.6 & 7.0 & 3.6 \\
\hline EQAR & $\mathrm{N}$ & 0.0 & 0.0 & 0.0 & 0.4 & 0.0 & 0.0 & 0.0 \\
\hline GAsp & $\mathrm{N}$ & 0.0 & 0.0 & 0.0 & 0.0 & 0.0 & 0.0 & 3.6 \\
\hline JUAC & $\mathrm{N}$ & 0.0 & 0.0 & 0.0 & 0.0 & 0.0 & 0.4 & 0.0 \\
\hline PACA & $\mathrm{N}$ & 2.8 & 0.0 & 0.0 & 0.0 & 0.0 & 0.0 & 1.2 \\
\hline POsp & $\mathrm{N}$ & 1.1 & 29.2 & 13.9 & 17.7 & 25.9 & 24.0 & 0.0 \\
\hline SGLA & $\mathrm{N}$ & 0.0 & 51.8 & 0.0 & 0.0 & 1.5 & 0.0 & 0.0 \\
\hline SALA & $\mathrm{N}$ & 0.0 & 0.0 & 0.1 & 2.6 & 0.4 & 0.0 & 0.1 \\
\hline SPDO & $\mathrm{N}$ & 0.0 & 0.0 & 0.0 & 0.0 & 1.9 & 1.1 & 9.6 \\
\hline SPEM & $\mathrm{N}$ & 0.0 & 0.0 & 0.0 & 0.0 & 9.5 & 0.0 & 0.0 \\
\hline FEAR & I & 1.1 & 0.0 & 0.0 & 0.0 & 0.0 & 0.0 & 0.0 \\
\hline LUPA & I & 0.0 & 2.0 & 0.0 & 0.0 & 14.4 & 0.0 & 0.0 \\
\hline PHAR & I & 47.5 & 9.0 & 86.1 & 64.9 & 38.0 & 60.6 & 54.2 \\
\hline SODO & I & 0.0 & 0.0 & 0.0 & 0.7 & 0.0 & 0.4 & 0.0 \\
\hline \multicolumn{2}{|c|}{ Totals } & 100.0 & 100.0 & 100.0 & 100.0 & 100.0 & 100.0 & 100.0 \\
\hline
\end{tabular}

${ }^{1} \mathrm{~N}=$ native, $\mathrm{I}=$ Introduced, nonnative 


\section{Results}

\section{Pond Vegetation Composition}

Nineteen plant species were found within the seven ponds (Appendix I gives the four-letter codes corresponding to the scientific and common names of the plant species discussed used hereafter). The ponds varied from a low of three species (Muskrat) to a high of 10 (Pancreas). Only four nonnative species were found among the seven ponds but reed canarygrass was by far the most frequent (Figure 12). Vegetation structure changed significantly in Kidney and Oak ponds during the winter (Table 3). Kidney pond changed markedly because of a reduction in wapato (Fig. 6). The cause of this reduction is unclear, but seasonal dieback and the 10 pairs of grazing mallard ducks (observed almost every day I collected data) were probably responsible. In Kidney Pond, scoring of winter vegetation composition revealed that Posp had increased 47\% (from 29\% during the September 1999 survey to $76 \%$ during the February 2000 survey). Similarly, PHAR increased $15 \%$ over the same period ( $9 \%$ to $24 \%$ ). In Oak pond, increases in were observed in Posp (18\% to $19 \%$ ), and PHAR (65\% to $68 \%$ ).

\section{Amphibian Species Composition}

The first eggs of the 2000 amphibian oviposition season at my study ponds were detected on 19 January in Oak Pond at a water temperature of $4.1^{\circ} \mathrm{C}$. These 
eggs consisted of egg packets of long-toed salamander. I made the first observation of northern red-legged frog egg masses on 3 February in Oak pond in water that was $6.9^{\circ} \mathrm{C}$. Pacific treefrog egg packets were not observed until 11 February in Butterfly pond at a water temperature of $6.3^{\circ} \mathrm{C}$. I also first observed egg masses of the northwestern salamander on 11 February at Kidney pond in $6.4^{\circ} \mathrm{C}$ water. I surveyed ponds only once or twice a week so these dates do not necessarily reflect the first day the egg masses or packets may have been deposited for each species. The numbers of northern red-legged frog egg masses varied from a low of 2 (Butterfly Pond) to a high of 133 (Oak Pond) (Figure 13). Northwestern salamander egg masses were observed in six of the seven ponds with none found in Butterfly Pond up to 23 found in Pancreas Pond (Figure 13). Egg packets for longtoed salamanders and Pacific treefrogs were observed in all ponds and were the most frequent species encountered in all ponds.

Table 3 shows the average temperatures and range of water temperatures in each pond during the four-month sampling interval. I observed a progressive increase in mean water temperature from February $\left(6.4^{\circ} \mathrm{C}\right.$; range: $\left.4.3-9.2^{\circ} \mathrm{C}\right)$ through May $\left(16.5^{\circ} \mathrm{C}\right.$; range: $\left.12.6-23.5^{\circ} \mathrm{C}\right)$. 
Figure 12 - Vegetation composition and oviposition use per pond of the four amphibians Plant species codes are in Appendix $\mathbf{H}$.

\section{Butterfly Pond Vegetation Composition vs. Oviposition Use}

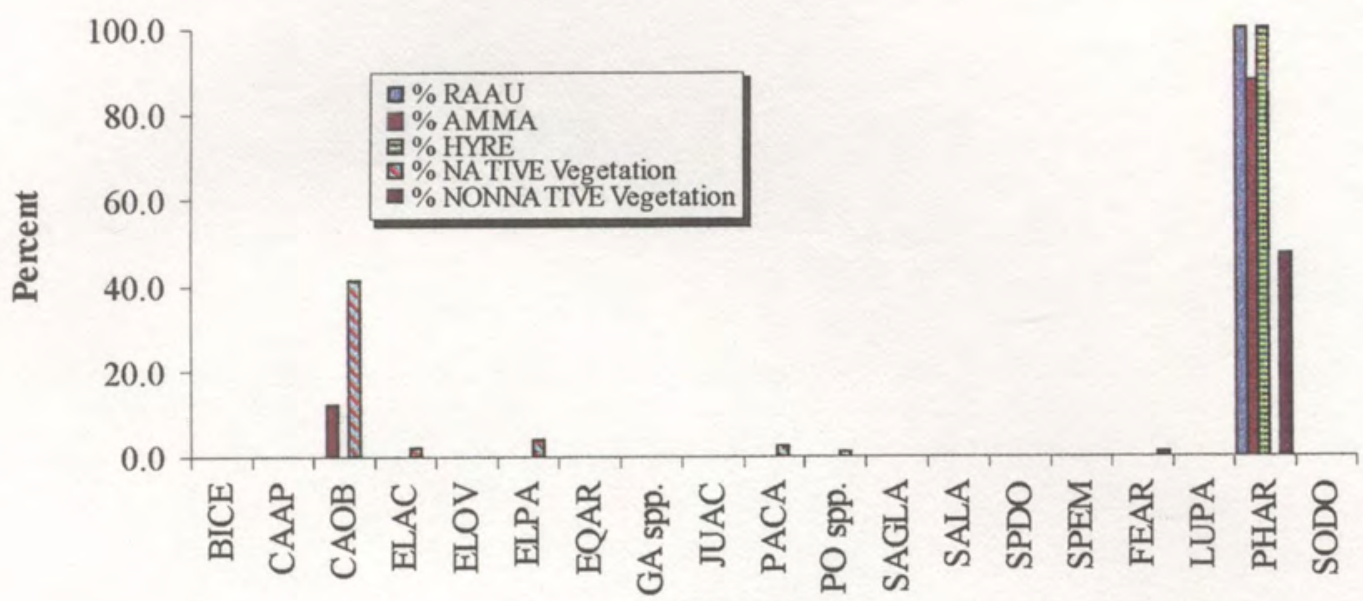

Plant Species

Kidney Pond Vegetation Composition vs. Oviposition Use

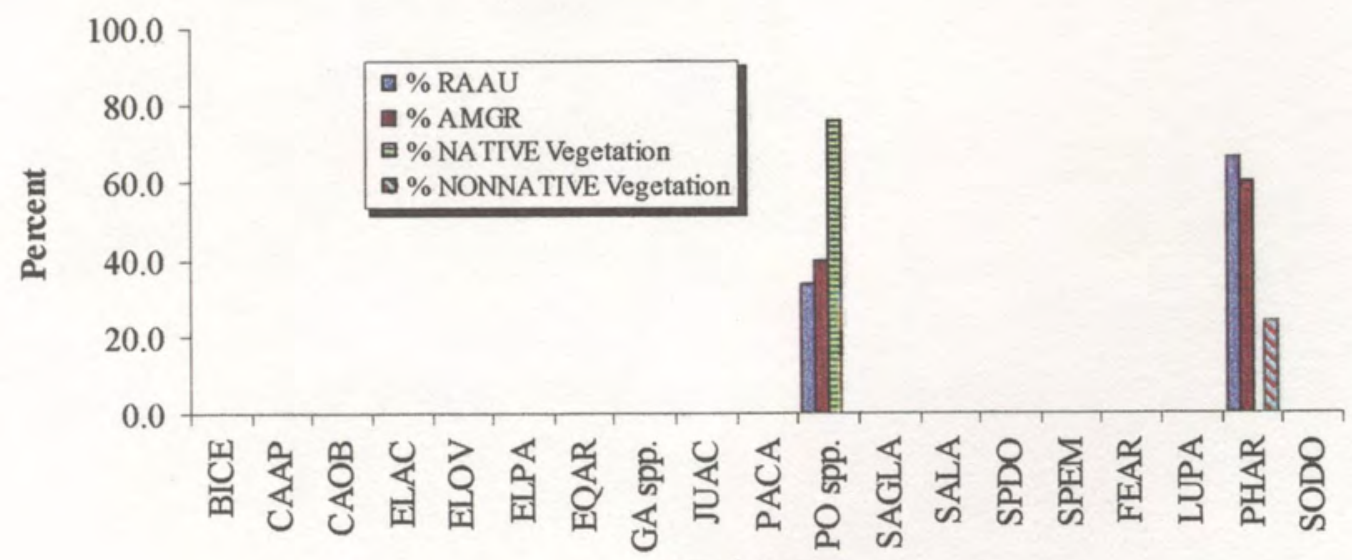

Plant Species 
Figure 12 - Vegetation composition and oviposition use per pond of the four amphibians (continued) Plant species codes are in Appendix $\mathbf{H}$.

\section{Muskrat Pond Vegetation Composition vs. Oviposition Use}

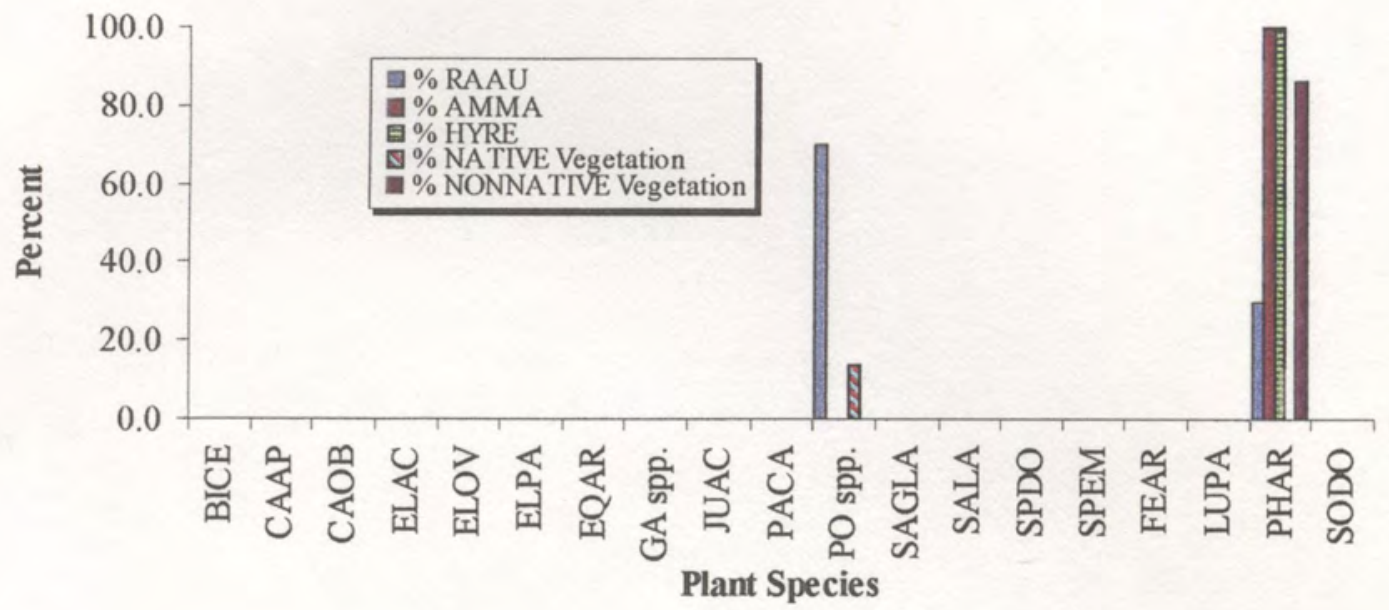

Oak Pond Vegetation Composition vs. Oviposition Use

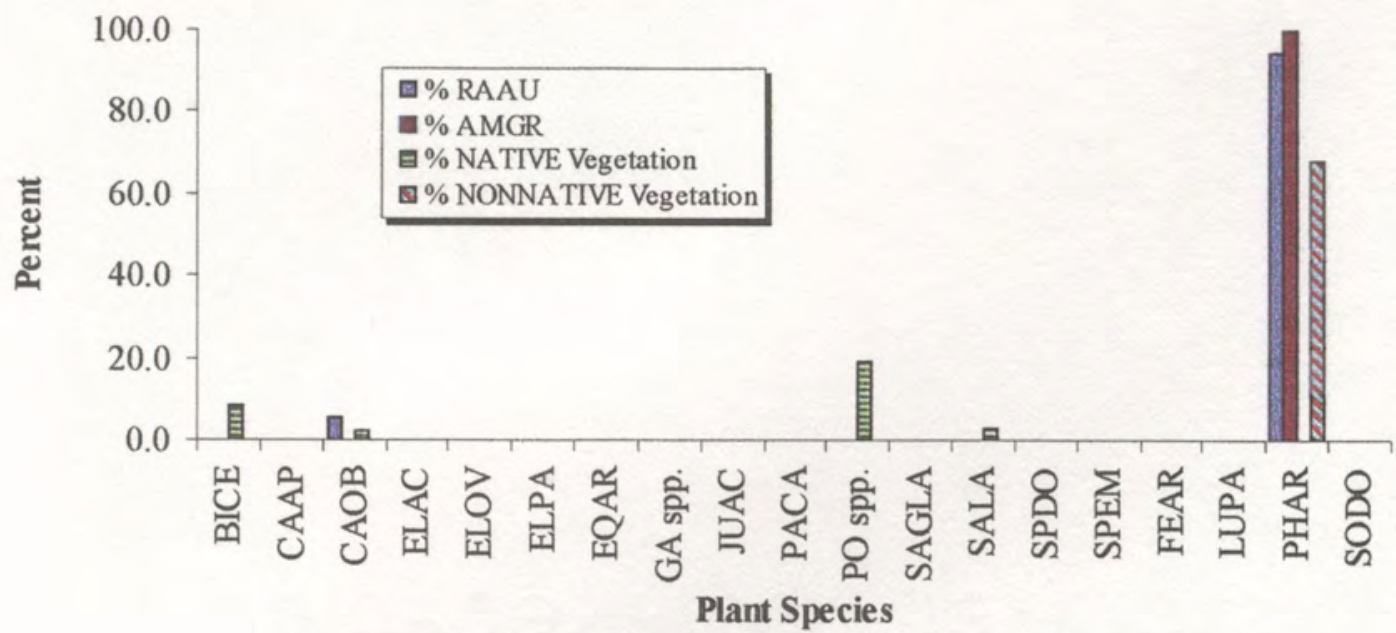


Figure 12 - Vegetation composition and oviposition use per pond of the four amphibians (continued) Plant species codes are in Appendix H.

\section{Pancreas Pond Vegetation Composition vs. Oviposition Use}

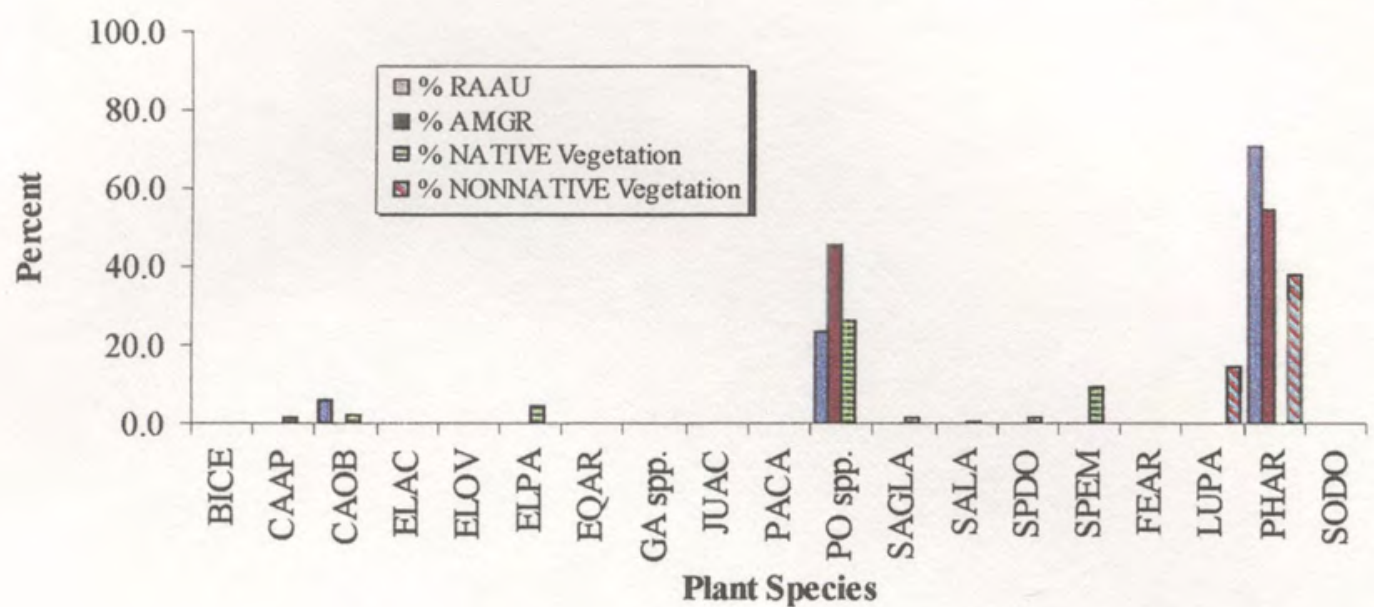

Sedge Pond Vegetation Composition vs. Oviposition Use

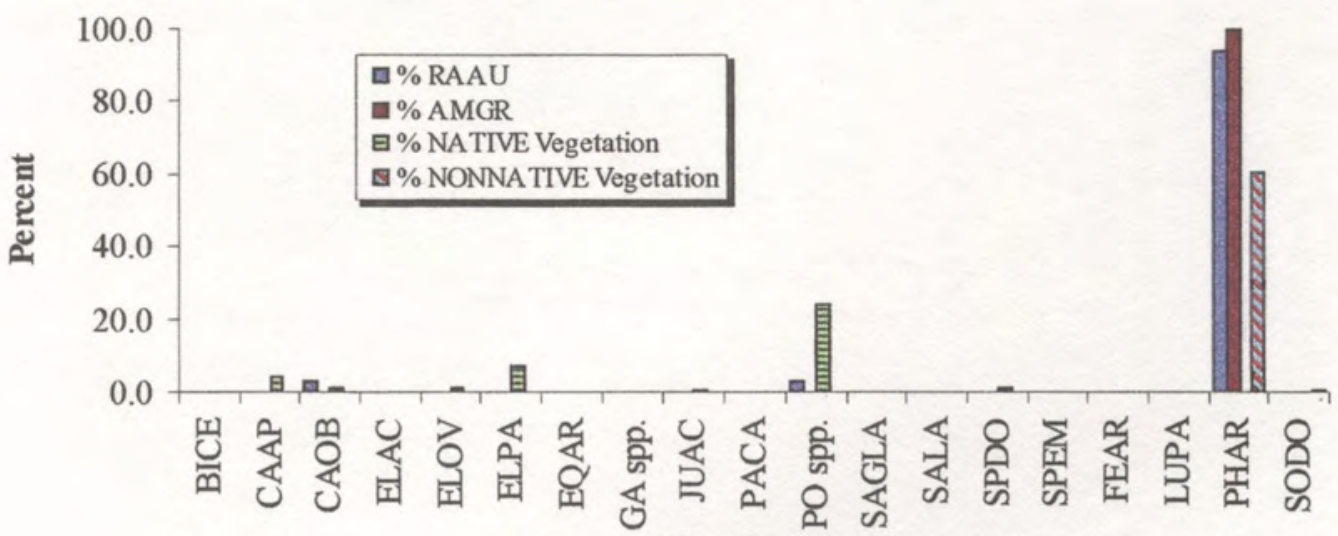

Plant Species 
Figure 12 - Vegetation composition and oviposition use per pond of the four amphibians (continued) Plant species codes are in Appendix H.

Spirea Pond Vegetation Composition vs. Oviposition Use

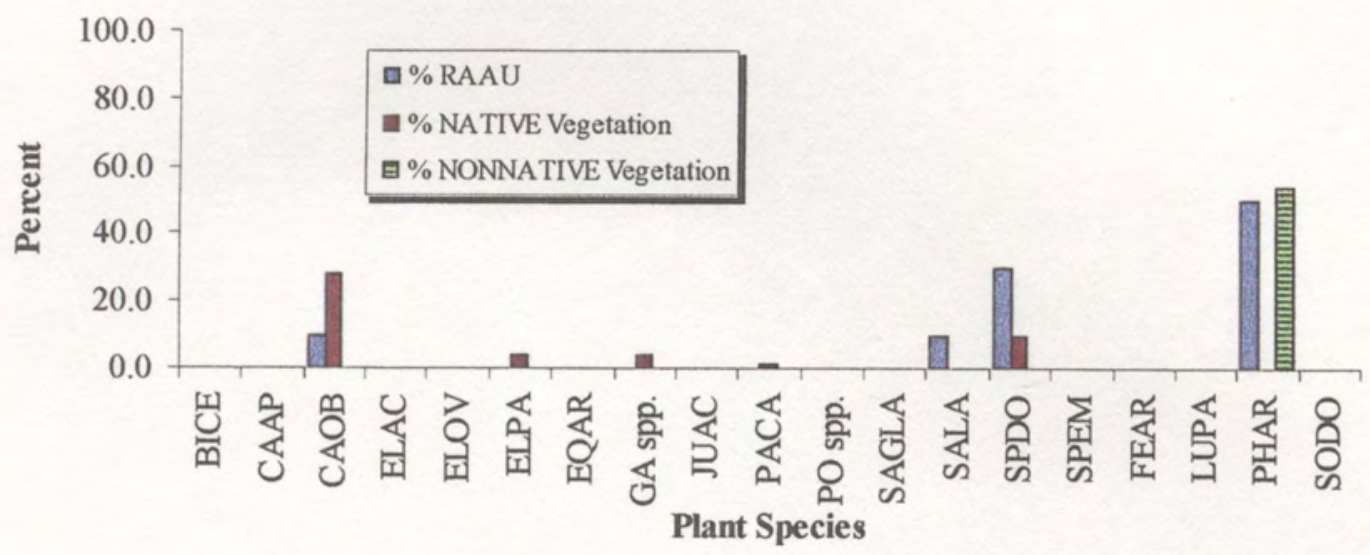


Figure 13 - Amphibian Egg Mass Count Per Pond

Rana aurora and Ambystoma gracile are actual counts. A subsample of 25 egg packets were taken for each of Hyla regilla and Ambystoma macrodactylum in Butterfly and Muskrat Ponds although they were observed in all seven ponds and were the most abundant species in all ponds. Oak was the largest pond in surface area with the largest number of egg masses. Pancreas and Sedge were third and fourth largest in area but had greater numbers of RAAU and AMGR combined than Kidney, which was second in surface area. Kidney also had very little available vegetation in the center of the pond.

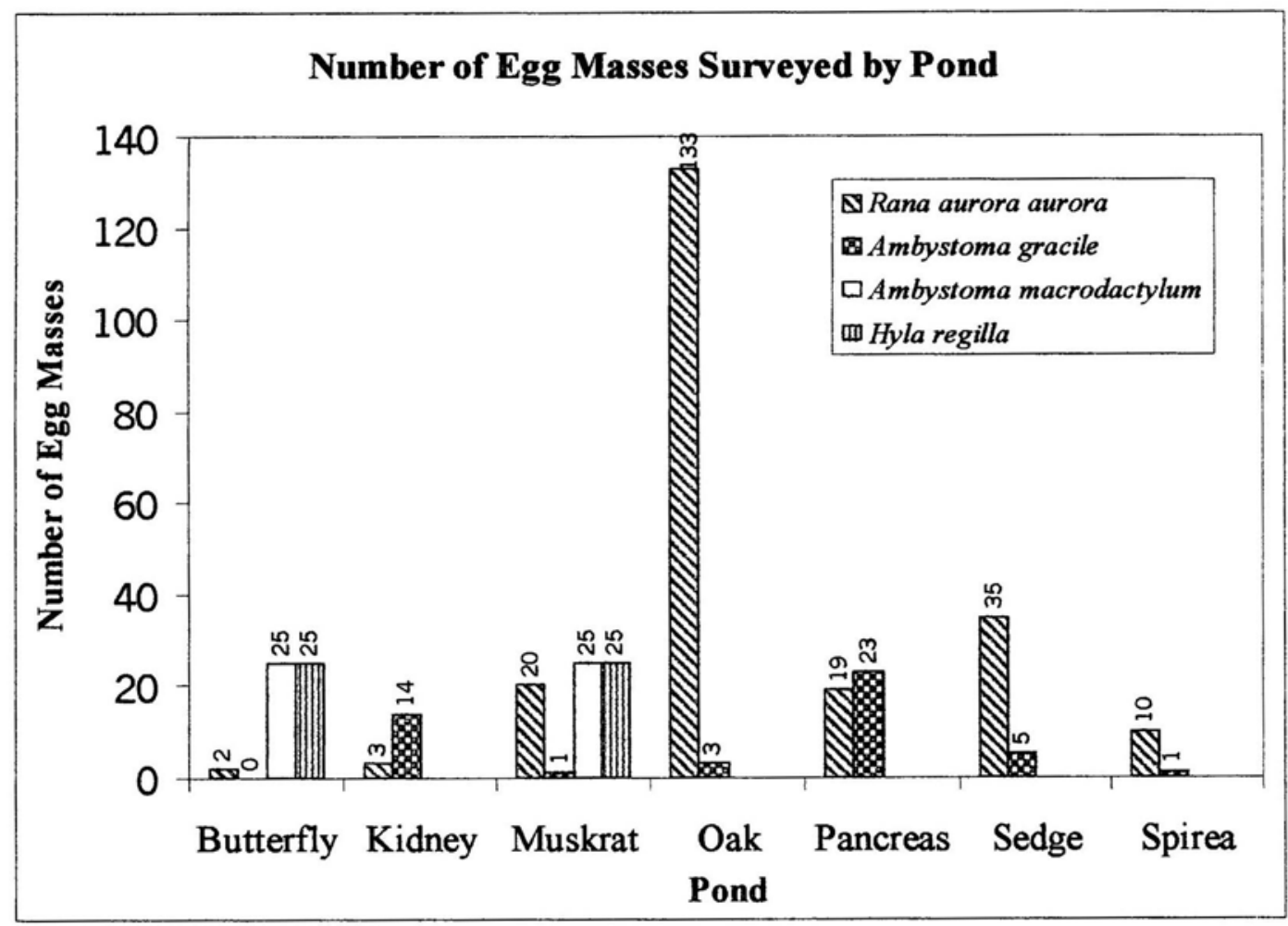

Table 4 - Pond Water Temperatures, February-April 2000

Temperatures were recorded hourly. Spirea and Butterfly Ponds almost dried at the end of March and temperature ranges were calculated excluding the interval when the data loggers were exposed to air.

\begin{tabular}{|c|c|c|c|c|c|c|c|c|c|c|c|c|}
\hline & \multicolumn{12}{|c|}{ HOBO Data Logger Water Temperatures (Celsius) } \\
\hline & \multicolumn{3}{|c|}{ February } & \multicolumn{3}{|c|}{ March } & \multicolumn{3}{|c|}{ April } & \multicolumn{3}{|c|}{ May } \\
\hline & $\operatorname{Max}$ & Mean & Min & $\operatorname{Max}$ & Mean & Min & $\operatorname{Max}$ & Mean & Min & $\operatorname{Max}$ & Mean & Min \\
\hline & $\overline{9.18}$ & 6.76 & 4.34 & 12.23 & 9.04 & $\overline{5.84}$ & 20.65 & 15.06 & 9.47 & 17.45 & 15.71 & 13. \\
\hline Kidney & 8.52 & 7.18 & 5.84 & 13.98 & 10.73 & $\overline{\overline{7.48}}$ & \begin{tabular}{|l|l|}
19.94 \\
\end{tabular} & 15.64 & 11.34 & 20.36 & 17.41 & 4.45 \\
\hline Musk & 07 & 5.40 & 4.73 & 10.40 & 8.47 & 6.54 & 19.22 & 14.66 & 10.09 & 23.50 & 18.05 & 12.59 \\
\hline Oak & 21 & 6.39 & 5.57 & 10.02 & 8.72 & $\overline{7.41}$ & 15.79 & 14.14 & 12.48 & 19.18 & 17.34 & 15.50 \\
\hline 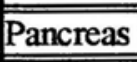 & 99 & 6.29 & 5.58 & 10.85 & 9.40 & $\overline{7.96}$ & 15.50 & 13.91 & 12.32 & 17.30 & 15.84 & 14.38 \\
\hline Sedge & 7.04 & 6.28 & 5.52 & 10.28 & 8.75 & 7.22 & 16.18 & 13.28 & 10.38 & 19.70 & 16.33 & 12.96 \\
\hline Spirea & 8.07 & 6.81 & 5.55 & 14.44 & 9.46 & $\overline{4.48}$ & 20.91 & 14.70 & 8.50 & 16.96 & 14.91 & 12.86 \\
\hline
\end{tabular}




\section{Exotic Vegetation Hypothesis}

Based on Fall 1999 surveys, ponds varied over two-fold in the percentage of native vegetation cover. Ranked in descending order of percentage of native vegetation (in parentheses), the ponds were Kidney (88.9\%), Muskrat (86.1\%), Butterfly (51.4\%), Pancreas (47.5\%), Spirea (44.5\%), Sedge (39.6\%), and Oak (33.4\%) (Figs. $14-17)$.

Analysis of oviposition substrate use by all of the amphibians (Table 5) showed a heavier than expected use of nonnative vegetation in over half the analyses and none showed a heavier than expected use of native vegetation (Table 6).

Of the five ponds in which RAAU was common, three (Muskrat, Sedge, and Oak) showed significantly greater use of nonnative vegetation (Figure 14).

Pancreas and Spirea Ponds failed to reveal significant differences between native and nonnative substrate use.

Only one of two ponds analyzed for AMGR vegetation use, Kidney, showed significantly greater use of nonnative PHAR (60\%) than would be expected, but this difference was not large.

Analysis of AMMA and HYRE vegetation brace use in Butterfly and Muskrat Ponds revealed significant use of nonnative braces in only Butterfly Pond (100\%). 
Both HYRE and AMMA used only PHAR in Muskrat Pond also but it was not statistically significant.

Table 5 - Amphibian Egg Mass Numbers, 2000 Reproductive Season Ponds with less than 10 egg masses were not analyzed. These are all egg masses or packets that were attached to vegetation and not floating near vegetation.

\begin{tabular}{|l|c|c|c|c|}
\hline \multirow{2}{*}{ Pond } & \multicolumn{4}{|c|}{ Number of Egg Masses or Packets (n) } \\
\cline { 2 - 5 } & Raau & Amgr & Hyre & Amma \\
\hline Butterfly & 2 & 0 & 25 & 25 \\
Kidney & 3 & 15 & 0 & 0 \\
Muskrat & 20 & 1 & 25 & 25 \\
Oak & 124 & 3 & 0 & 0 \\
Pancreas & 18 & 23 & 0 & 0 \\
Sedge & 36 & 5 & 0 & 0 \\
Spirea & 10 & 1 & 0 & 0 \\
\hline
\end{tabular}

Table 6 - Use versus availability of native versus nonnative substrates for each amphibian species, 2000 reproductive season

\begin{tabular}{|cccc|}
\hline Species & Pond & Chi-Square & Sig \\
\hline \hline & Muskrat & 47.5 & $*$ \\
RAAU & Oak & 56.1 & $*$ \\
& Pancreas & 3.4 & \\
& Sedge & 16.8 & $*$ \\
& Spirea & 0.4 & \\
\hline \multirow{2}{*}{ AMGR } & Kidney & 8.5 & $*$ \\
& Pancreas & 0 & \\
\hline \multirow{2}{*}{ HYRE } & Butterfly & 27.1 & * \\
& Muskrat & 4.8 & \\
\hline \multirow{2}{*}{ AMMA } & Butterfly & 16 & \\
& Muskrat & 4.8 & \\
\hline
\end{tabular}


Figure 14 - Native versus exotic substrate use for the northern red-legged frog Percent of total egg masses found in native and nonnative categories was calculated and compared to the percent of vegetation available in each category. Ponds are shown alphabetically. Only Oak, Sedge and Muskrat Ponds revealed significant differences in used versus available vegetation.

Butterfly Pond-Rana aurora aurora Oviposition Substrate Use

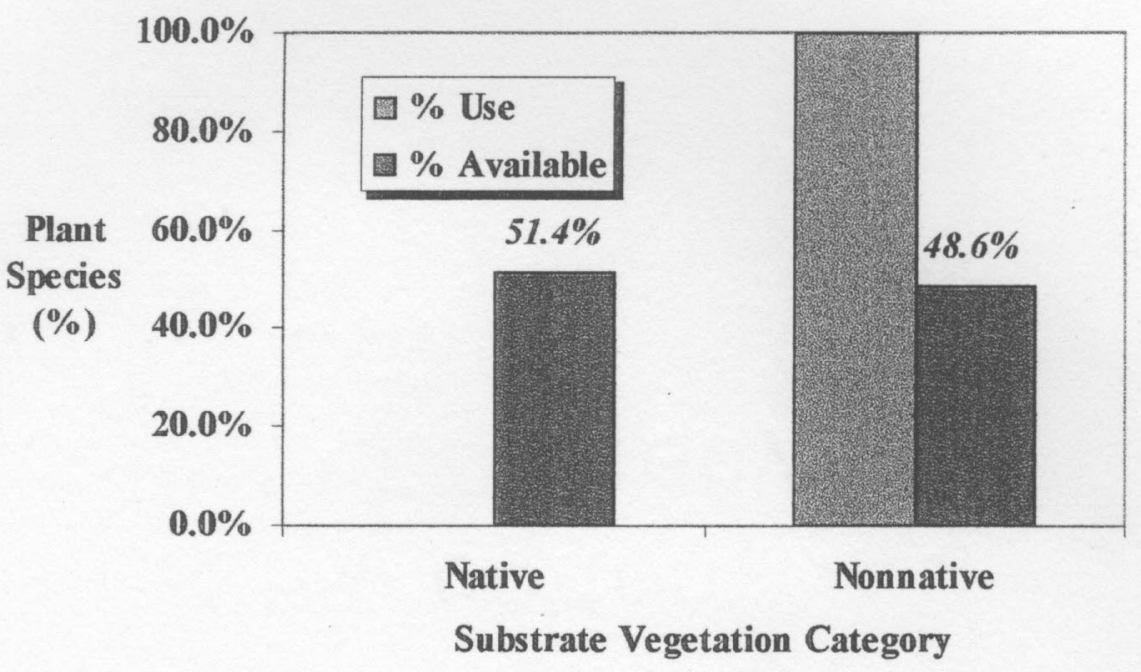

Kidney Pond-Rana aurora aurora Oviposition Substrate Use

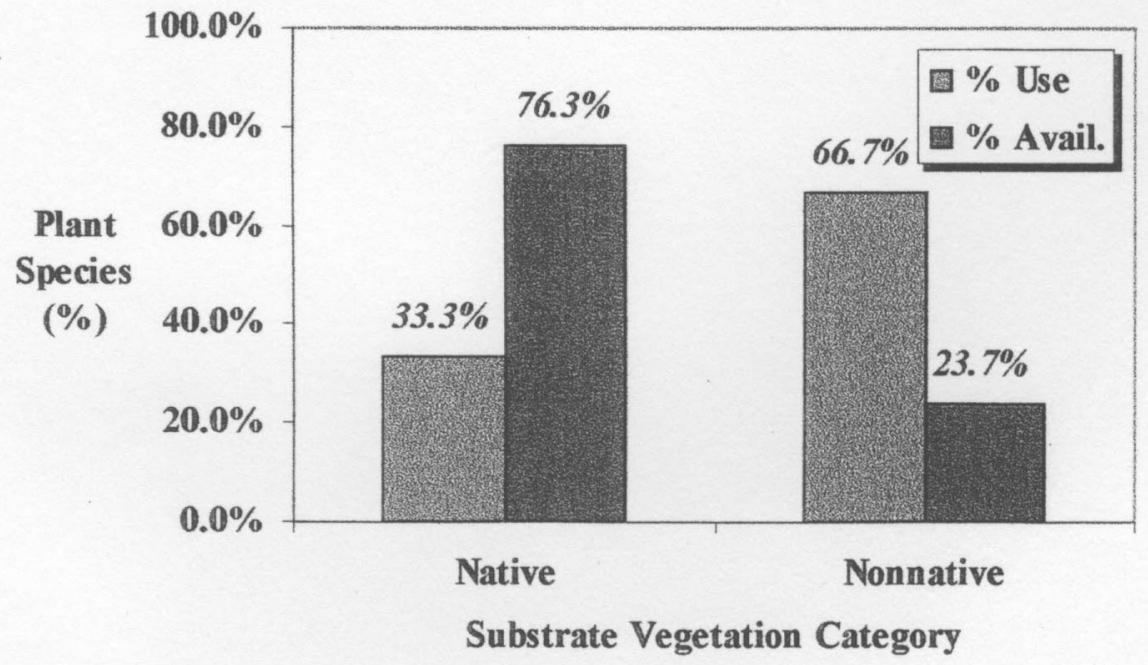


Figure 14 - Native versus exotic substrate use for the northern red-legged frog (continued)

Percent of total egg masses found in native and nonnative categories was calculated and compared to the percent of vegetation available in each category. Ponds are shown alphabetically. Only Oak, Sedge and Muskrat Ponds revealed significant differences in used versus available vegetation.

\section{Muskrat Pond - Rana aurora aurora Oviposition Substrate Use}

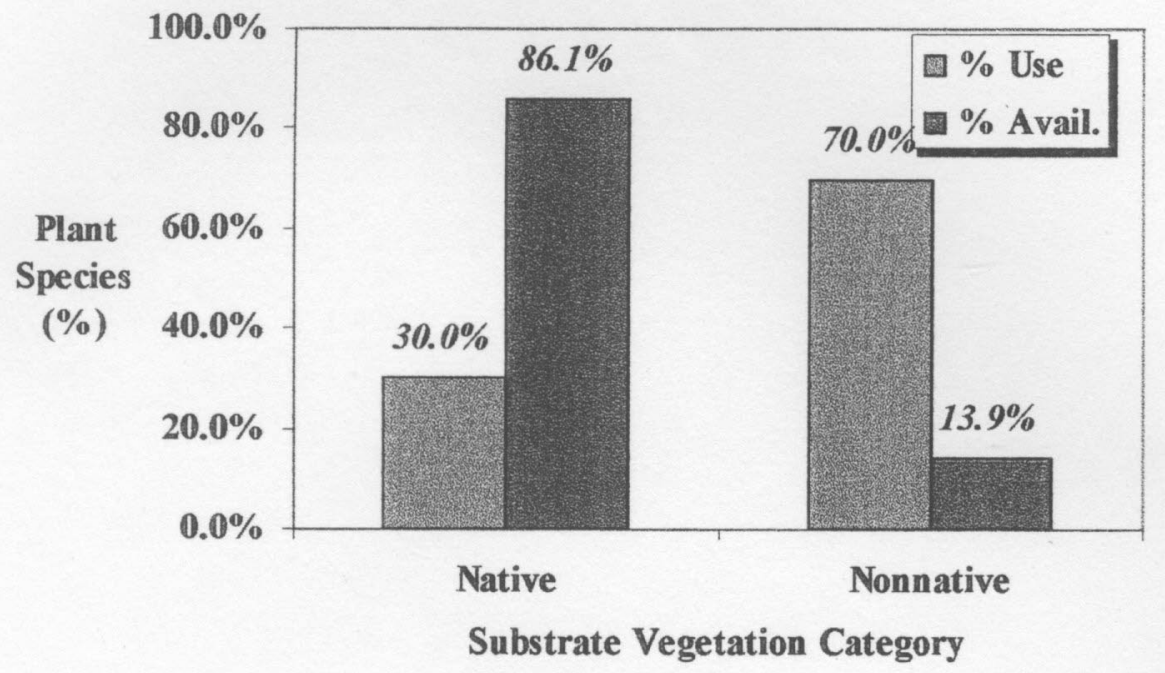

Oak Pond -Rana aurora aurora Oviposition Substrate Use

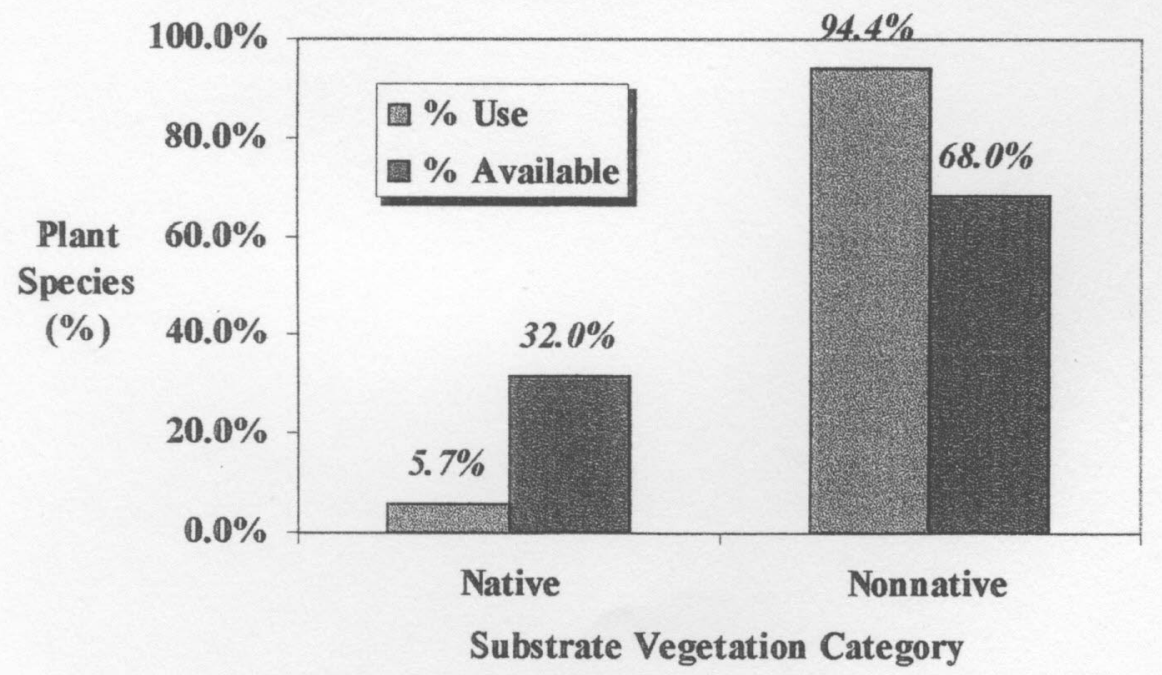


Figure 14 - Native versus exotic substrate use for the northern red-legged frog (continued)

Percent of total egg masses found in native and nonnative categories was calculated and compared to the percent of vegetation available in each category. Ponds are shown alphabetically. Only Oak, Sedge and Muskrat Ponds revealed significant differences in used versus available vegetation.

Pancreas Pond - Rana aurora aurora Oviposition Substrate Use

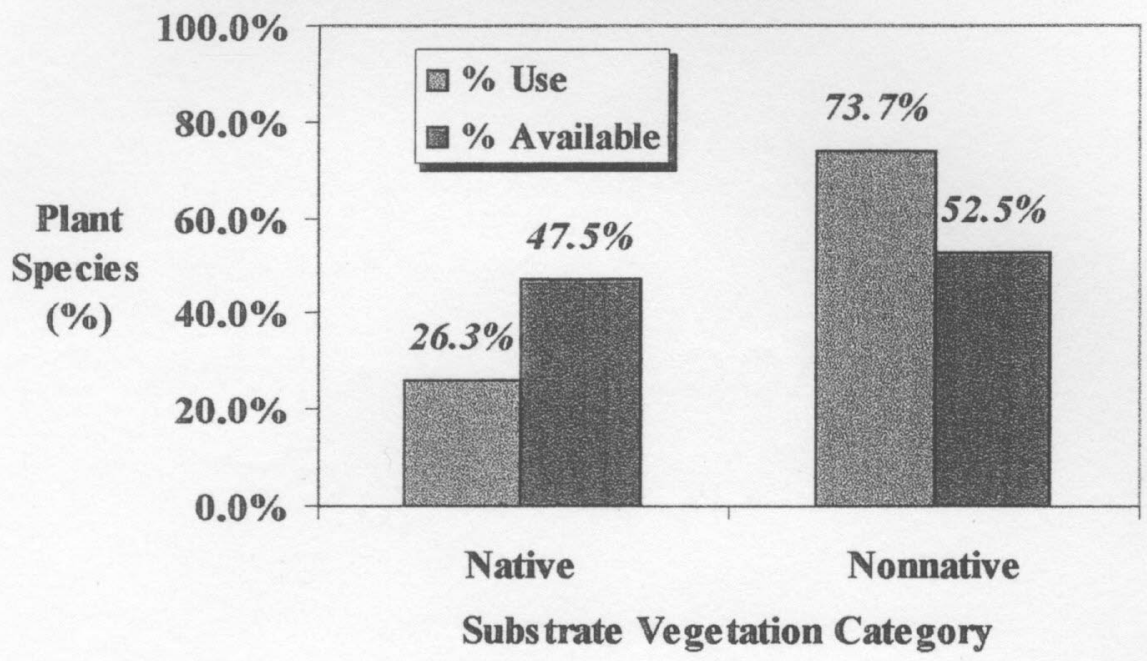

Sedge Pond - Rana aurora aurora Oviposition Substrate Use

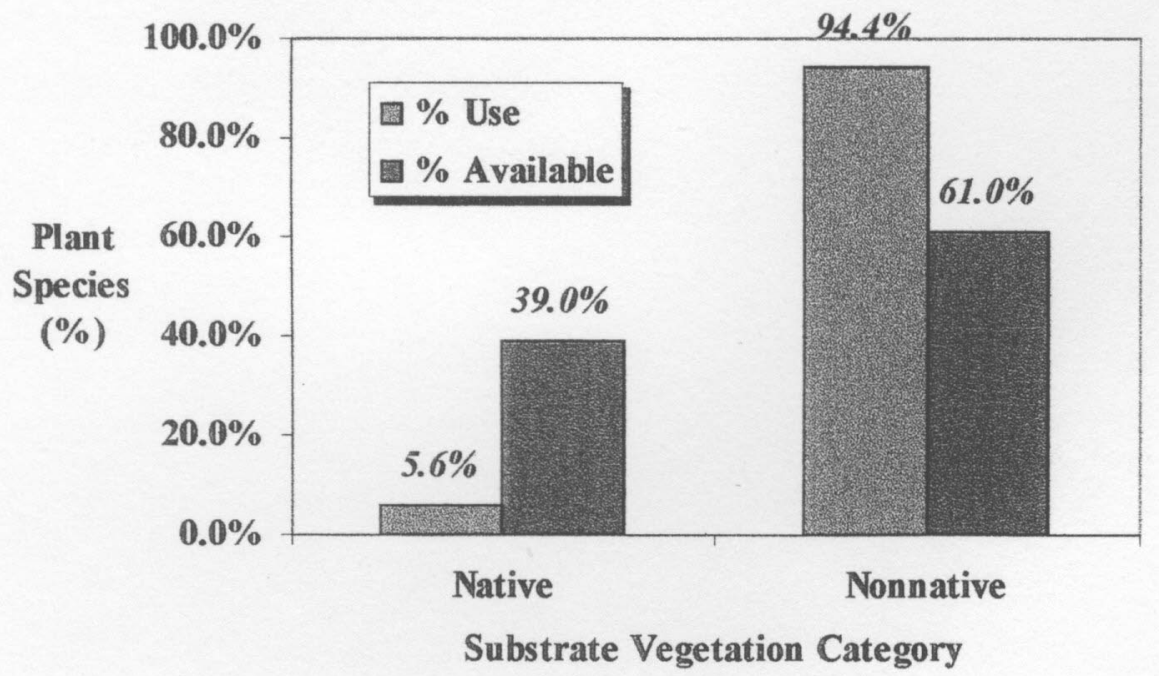


Figure 14 - Native versus exotic substrate use for the northern red-legged frog (continued)

Percent of total egg masses found in mative and nonnative categories was calculated and compared to the percent of vegetation available in each category. Ponds are shown alphabetically. Only Oak, Sedge and Muskrat Ponds revealed significant differences in used versus available vegetation.

Spirea Pond - Rana aurora aurora Oviposition Substrate Use

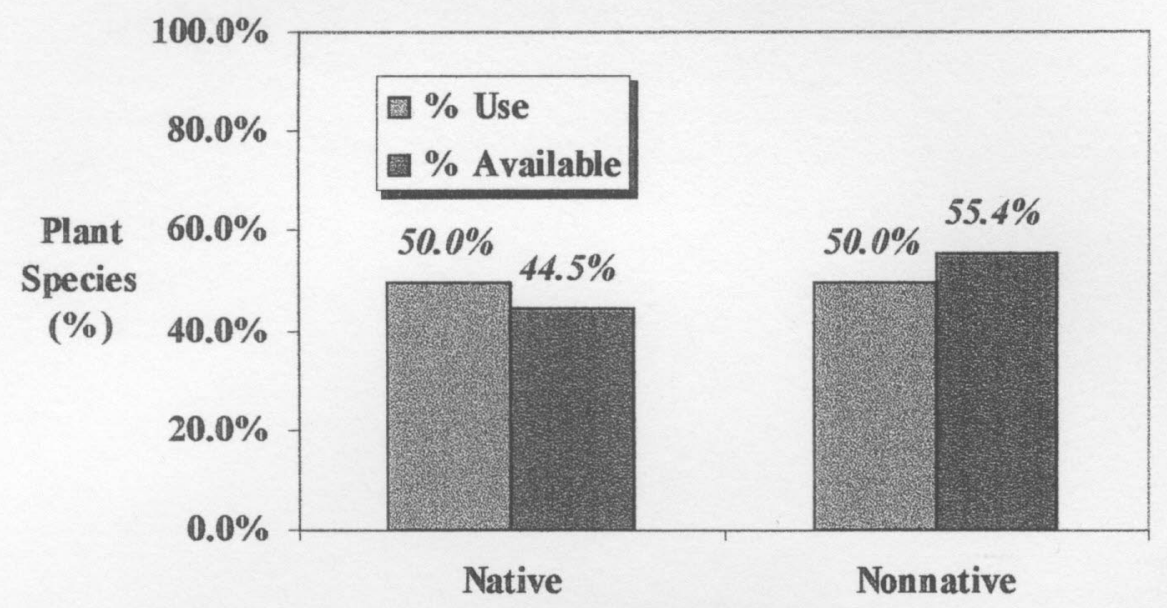

Substrate Vegetation Category 
Figure 15 - Native versus exotic substrate use for the northwestern salamander Only two ponds had more than $\mathbf{1 0}$ egg masses and were available for analysis. Only Kidney Pond showed slightly more significant use of nonnative reed canarygrass than would be expected.

Kidney Pond - Ambystoma gracile Oviposition Substrate Use

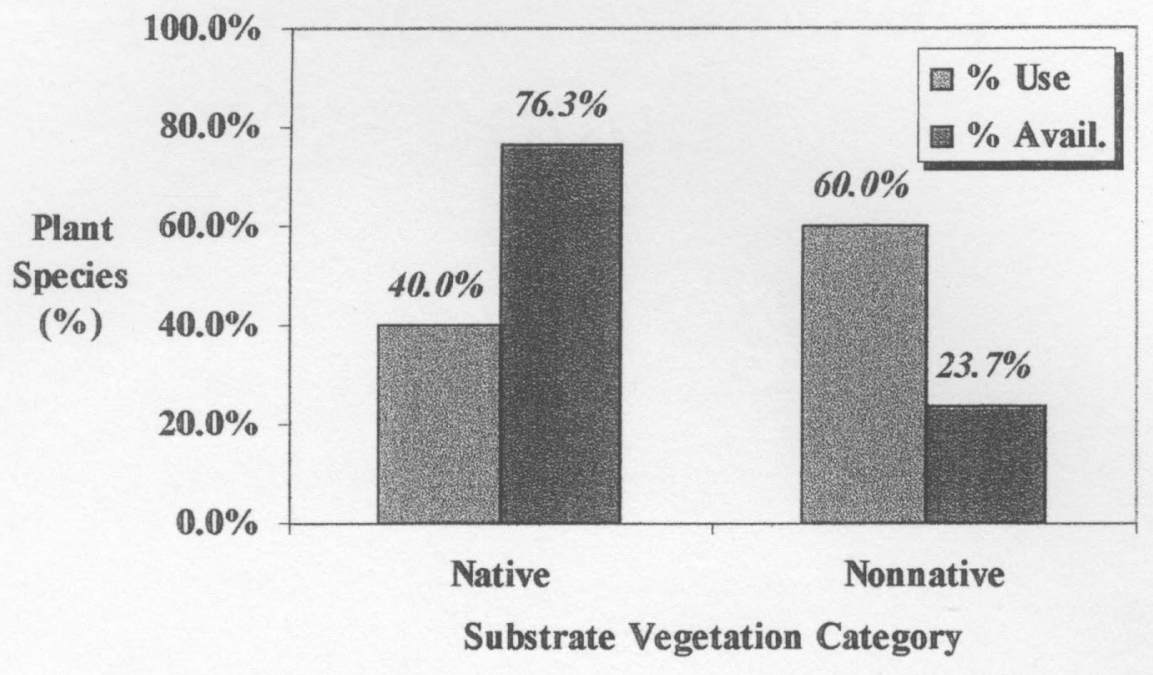

Pancreas Pond - Ambystoma gracile Oviposition Substrate Use

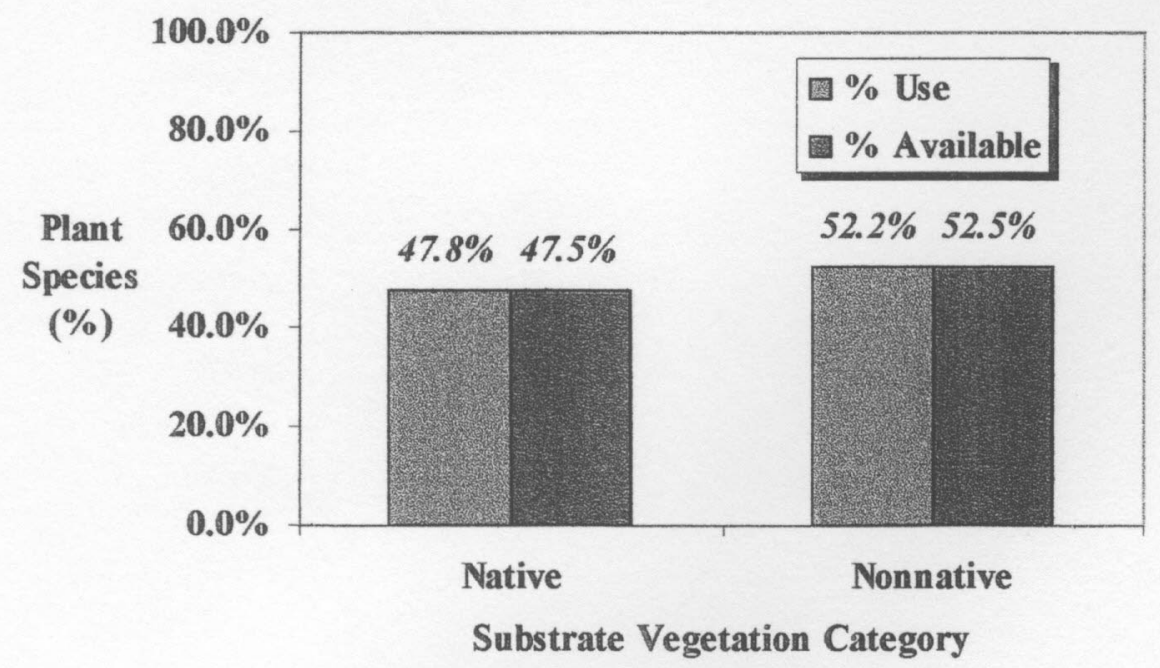


Figure 15 - Native versus exotic substrate use for the northwestern salamander (continued)

Only two ponds had greater than 10 egg masses and could be analyzed using Chi-square. Kidney Pond showed slightly more significant use of nonnative reed canarygrass than would be expected.

Sedge Pond - Ambystoma gracile Oviposition Substrate Use

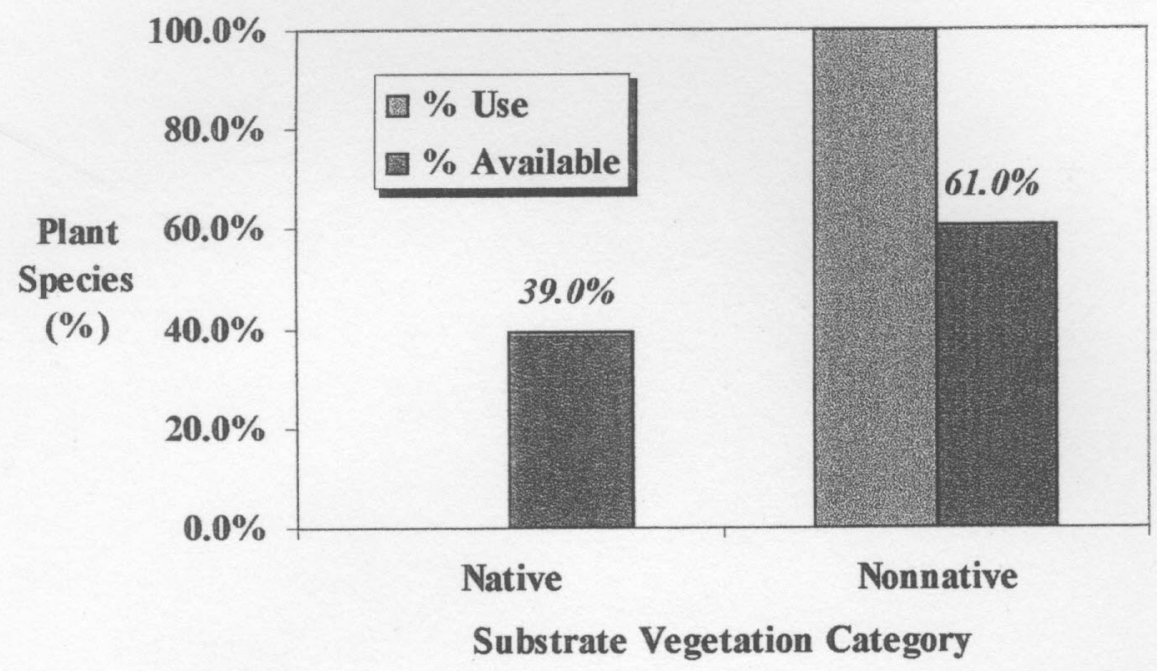

Kidney Pond - Ambystoma gracile Oviposition Substrate Use

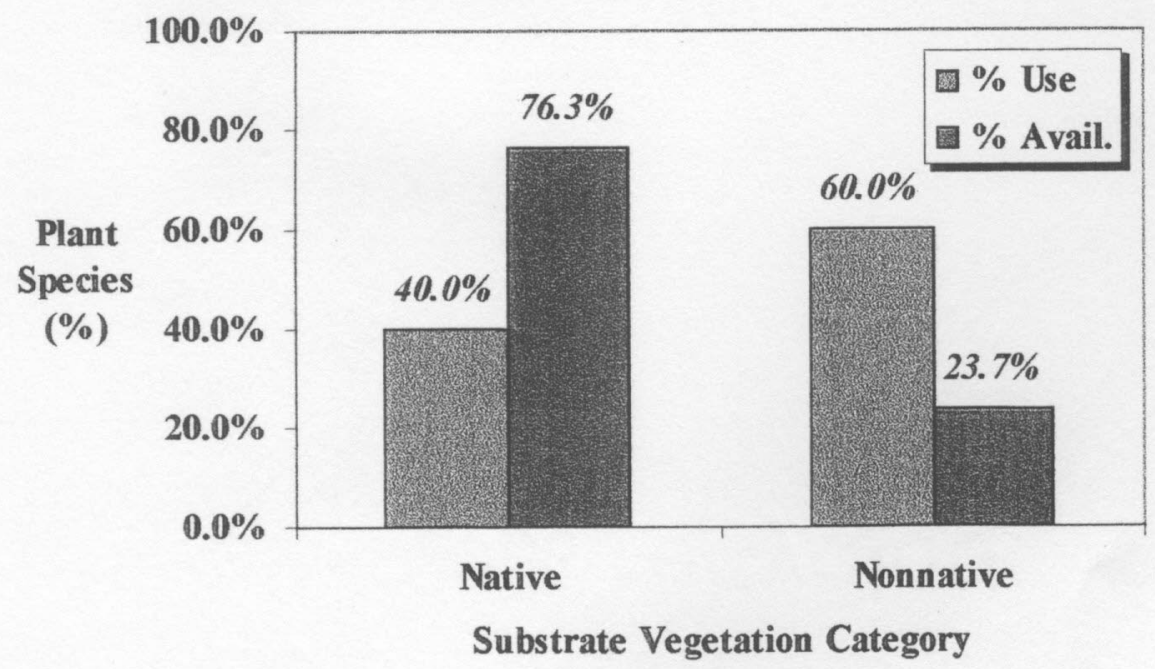


Figure 16 - Native versus exotic substrate use for the long-toed salamander Of the two ponds sampled for this species, only Butterfly pond revealed significant use of nonnative vegetation.

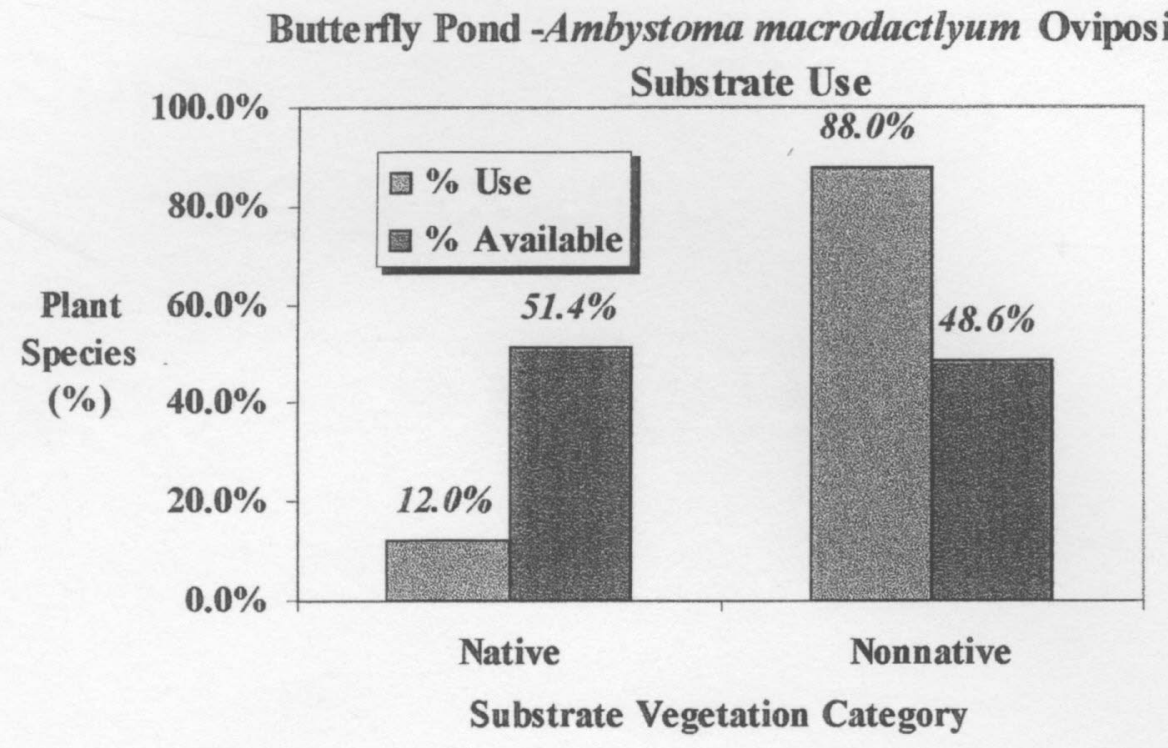

Muskrat Pond - Ambystoma macrodactylum Oviposition Subs trate

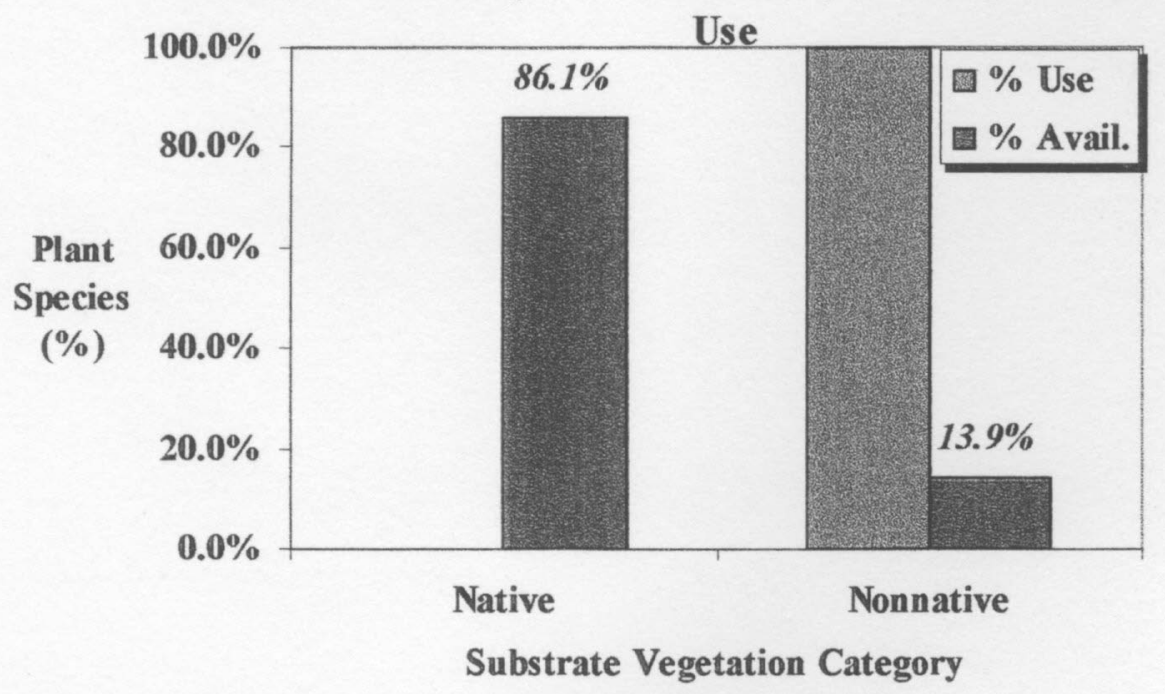


Figure 17 - Native versus exotic substrate use in the Pacific treefrog Of the two ponds sampled for this species, only Butterfly pond revealed significant use of nonnative vegetation

Butterfly Pond-Hyla regilla Oviposition Substrate Use

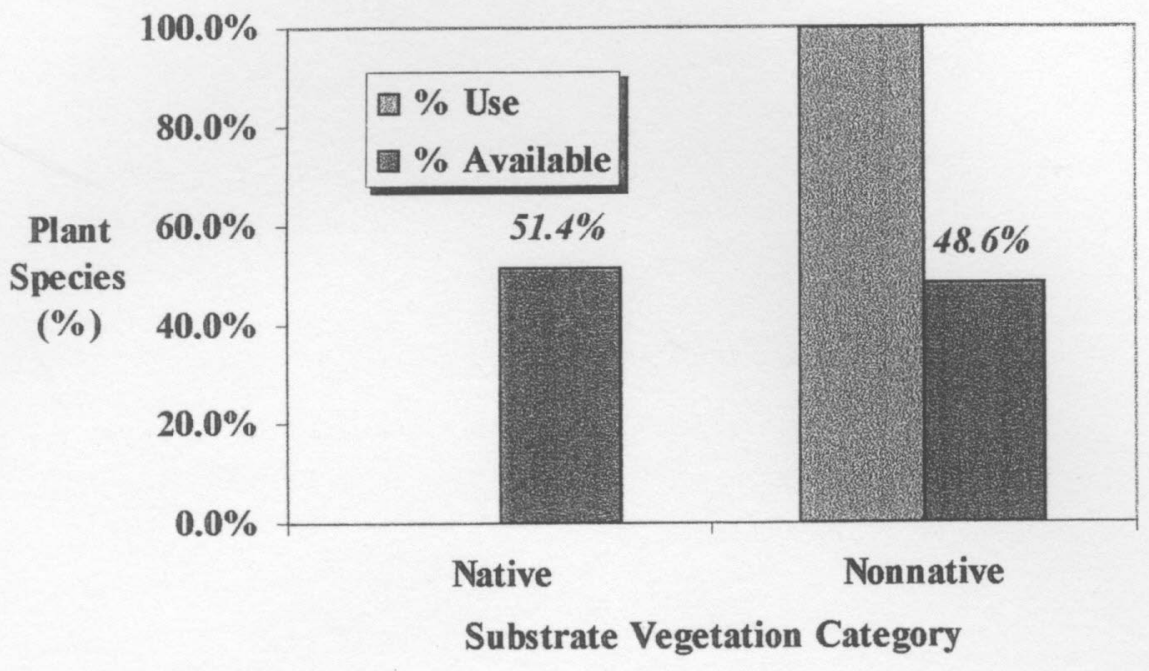

Muskrat Pond - Hyla regilla Oviposition Substrate Use

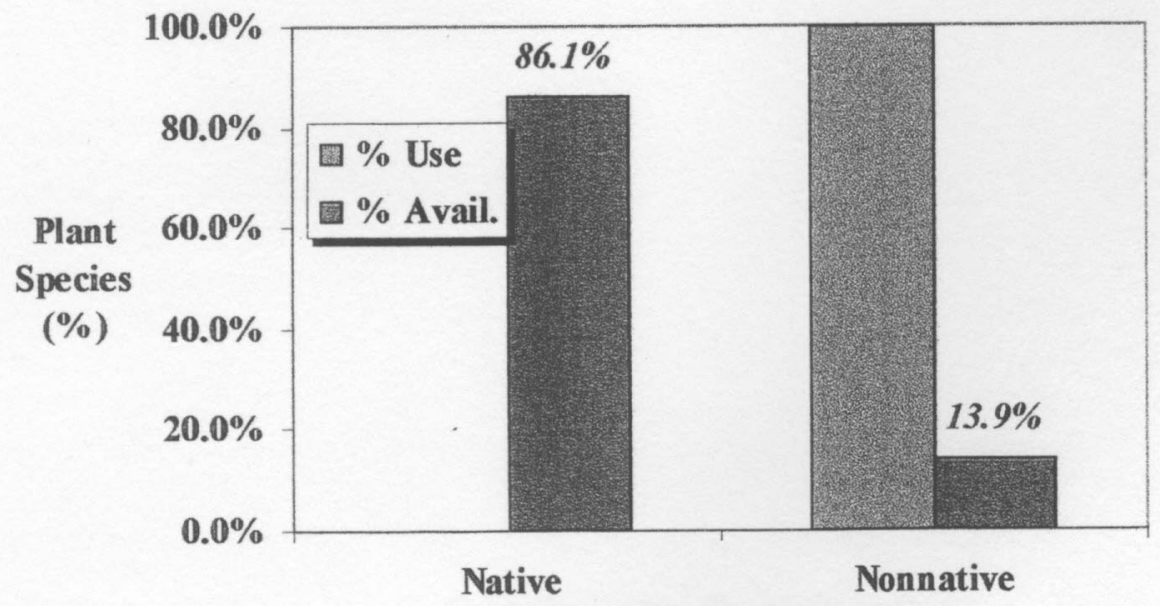

Substrate Vegetation Category 


\section{Substrate Strength Hypothesis}

Only five of the 19 plant species available in the study ponds were used for oviposition. My analysis of "strength" of the oviposition substrate revealed that each species differed significantly in mass, density, and diameter (Tables 7 and 8). In descending order of strength, the plants used for oviposition included Pacific willow (SALA), hardhack (SPDO), sedge (CAOB), water pepper (POsp.), and reed canarygrass (PHAR).

In three of the five ponds with adequate numbers of egg masses to analyze (Pancreas, Sedge, Oak), the northern red-legged frogs used the weaker reed canarygrass (PHAR) significantly more than would be expected based on its availability (Table 9). Only in Muskrat pond was the stronger substrate, water pepper (Posp), used significantly more than expected (Table 10).

The northwestern salamander oviposited on only one species, PHAR, significantly more than expected in one out of three ponds (Kidney) analyzed (Sedge and Pancreas) (Table 11). Again, this was not the strongest species available.

Pacific treefrogs (Table 12) and long-toed salamanders (Table 13) laid eggs on PHAR significantly more than would be expected in Butterfly Pond. The longtoed salamanders also used sedge ( $\mathrm{CAOB}$ - the third-ranked species in strength) in Butterfly Pond, but less than would be expected. Slightly more use of PHAR was 
found in Muskrat Pond for both Pacific treefrog and long-toed salamanders (Table 9).

Tables 10-13 also show the substrate species ranks according to relative structural complexity. Most of the plants used for oviposition were substrates with higher complexity ranking, but use differences existed among amphibians. Northern redlegged frogs utilized the greatest variety of vegetation braces of the four species using single stems, single leaves, multiple stems, multiple leaves, and a combination of stems and leaves (Appendix J). Only six northern red-legged egg masses were found unattached and floating on the surface of the water. These floaters may have been knocked off by wave action, by an animal moving through the water, or simply detached as the eggs neared hatching. Of the 45 northwestern salamander egg masses found, 41 were on single stems, 1 was on two stems, and 3 were on multiple leaves (Appendix J). Forty-six of the 50 total small egg packets of long-toed salamanders and Pacific treefrogs sampled in Butterfly and Muskrat Ponds were found on either a single leaf or stem. The other four egg packets were found on multiple leaves or multiple smaller diameter stems but none were found on more than two braces (Appendix J). 
Table 7 - Variation in oviposition substrate mass, density, and diameter

\begin{tabular}{|c|c|c|c|c|c|c|c|c|}
\hline Variable & Stem & $\mathbf{N}$ & $\begin{array}{c}\text { MEAN } \\
(\mathbf{g})\end{array}$ & $\begin{array}{l}\text { STD } \\
\text { DEV }\end{array}$ & $\begin{array}{l}\text { STD } \\
\text { ERROR }\end{array}$ & $\begin{array}{c}95 \% \\
\text { CONFIDENCE } \\
\text { INTERVAL } \\
\text { FOR MEAN }\end{array}$ & MIN & MAX \\
\hline \multirow{6}{*}{ MASS } & PHAR & 34 & 0.0615 & 0.0499 & 0.0086 & $0.0441-0.0789$ & 0.01 & 0.20 \\
\hline & $\mathrm{CAOB}$ & 10 & 0.1900 & 0.0963 & 0.0304 & $0.1211-0.2589$ & 0.07 & 0.32 \\
\hline & SPDO & 26 & 0.3296 & 0.1646 & 0.0423 & $0.2631-0.3961$ & 0.05 & 0.73 \\
\hline & SALA & 14 & 0.6914 & 0.5892 & 0.1575 & $0.3512-1.0316$ & 0.10 & 1.94 \\
\hline & POSP & 36 & 0.1258 & 0.5577 & 0.0093 & $0.1070-0.1447$ & 0.03 & 0.27 \\
\hline & TOTAL & 120 & 0.2231 & 0.2909 & 0.0266 & $0.1705-0.2757$ & 0.01 & 1.94 \\
\hline \multirow{6}{*}{ DENSITY } & PHAR & 34 & 0.2118 & 0.8885 & 0.0152 & $0.1808-0.2428$ & 0.10 & 0.51 \\
\hline & $\mathrm{CAOB}$ & 10 & 0.1130 & 0.04644 & 0.0147 & $0.0798-0.1462$ & 0.05 & 0.20 \\
\hline & SPDO & 26 & 0.5238 & 0.09716 & 0.0191 & $0.4846-0.5631$ & 0.34 & 0.72 \\
\hline & SALA & 14 & 0.4950 & 0.1861 & 0.0497 & $0.3876-0.6024$ & 0.25 & 0.99 \\
\hline & POSP & 36 & 0.6269 & 0.2254 & 0.0376 & $0.5507-0.7032$ & 0.17 & 1.08 \\
\hline & TOTAL & 120 & 0.4288 & 0.2434 & 0.0222 & $0.3847-0.4728$ & 0.05 & 1.08 \\
\hline \multirow{6}{*}{ DIAM } & PHAR & 34 & 0.1835 & 0.0716 & 0.0123 & $0.1585-0.2085$ & 0.08 & 0.38 \\
\hline & $\mathrm{CAOB}$ & 10 & 0.4600 & 0.1506 & 0.0476 & $0.3523-0.5677$ & 0.20 & 0.70 \\
\hline & SPDO & 26 & 0.2731 & 0.0827 & 0.0162 & $0.2397-0.3065$ & 0.10 & 0.40 \\
\hline & SALA & 14 & 0.4000 & 0.1922 & 0.0514 & $0.2891-0.5109$ & 0.20 & 0.90 \\
\hline & POSP & 36 & 0.1778 & 0.0540 & 0.0090 & $0.1595-0.1961$ & 0.10 & 0.30 \\
\hline & TOTAL & 120 & 0.2495 & 0.1370 & 0.0125 & $0.2247-0.2743$ & 0.08 & 0.90 \\
\hline
\end{tabular}

Table 8 - Comparison of oviposition substrate variation ANOVA was used to compare the three measures used in the strength index within and among ponds.

\begin{tabular}{|c|c|c|c|c|c|c|}
\hline Variable & Comparison & $\begin{array}{l}\text { Sum of } \\
\text { Squares }\end{array}$ & $\begin{array}{l}\text { Degrees of } \\
\text { freedom (df) }\end{array}$ & $\begin{array}{l}\text { Mean } \\
\text { Square }\end{array}$ & $\mathbf{F}$ & $\begin{array}{c}\text { Significance } \\
\text { Level }\end{array}$ \\
\hline \multirow{3}{*}{ Mass } & Between Ponds & 4.604 & 4 & 1.151 & \multirow[t]{3}{*}{24.224} & \multirow[t]{3}{*}{$<0.0005$} \\
\hline & Within Ponds & 5.465 & 115 & 0.048 & & \\
\hline & Total & 10.069 & 119 & & & \\
\hline \multirow{3}{*}{ Density } & Between Ponds & 4.308 & 4 & 1.077 & \multirow{3}{*}{45.146} & \multirow{3}{*}{$<0.0005$} \\
\hline & Within Ponds & 2.744 & 115 & 0.024 & & \\
\hline & Total & 7.052 & 119 & & & \\
\hline \multirow{3}{*}{ Diameter } & Between Ponds & 1.108 & 4 & 0.277 & \multirow{3}{*}{28.267} & \multirow{3}{*}{$<0.0005$} \\
\hline & Within Ponds & 1.127 & 115 & 0.010 & & \\
\hline & Total & 2.235 & 119 & & & \\
\hline
\end{tabular}


Table 9 - Use versus availability of specific oviposition substrates for each amphibian species, 2000 reproductive season

Comparison of the observed use of each substrate species to its expected use had the eggs been randomly placed. The expected value was calculated from the percentage of each substrate in the pond multiplied by the total number of egg masses. I adjusted the rejection criterion conservatively based on the number of tests for each species using Sidak's multiplicative inequality $\left(\alpha^{\prime}=1-(1-\alpha)^{1 / m}\right)$. Degrees of freedom based on how many substrate species were actually used. Substrate species not used were grouped into a collective category called "other" for each test.

\begin{tabular}{|c|c|c|c|c|c|}
\hline \multirow{2}{*}{ Pond } & \multirow{2}{*}{ Species } & \multicolumn{2}{|c|}{ Observed Values } & \multirow{2}{*}{ Critical $\chi^{\mathbf{2}}$} & $\begin{array}{c}\text { Degrees } \\
\text { of } \\
\text { freedom }\end{array}$ \\
\cline { 3 - 6 } & & \multicolumn{1}{c|}{$\chi^{2}$} & Probability & & 1 \\
\hline \multirow{2}{*}{ Butterfly } & HYRE & 27.64 & $<0.005$ & 5.025 & 2 \\
\cline { 2 - 6 } & AMMA & 16.64 & $<0.005$ & 7.378 & 1 \\
\hline Kidney & AMGR & 2.21 & $0.9>\mathrm{p}<0.1$ & 5.025 & 2 \\
\hline Muskrat & RAAU & 52.51 & $<0.005$ & 9.210 & 1 \\
\cline { 2 - 6 } & HYRE & 4.21 & $0.05>\mathrm{p}<0.025$ & 5.025 & 1 \\
\cline { 2 - 6 } & AMMA & 4.21 & $0.05>\mathrm{p}<0.025$ & 5.025 & 2 \\
\hline Oak & RAAU & 52.24 & $<0.005$ & 9.210 & 3 \\
\hline Pancreas & RAAU & 11.51 & $0.01>\mathrm{p}<0.005$ & 11.344 & 2 \\
\cline { 2 - 6 } & AMGR & 12.81 & $<0.005$ & 7.378 & 3 \\
\hline Sedge & RAAU & 17.94 & $<0.005$ & 11.344 & 4 \\
\hline Spirea & RAAU & 24.35 & $<0.005$ & 13.277 & \\
\hline
\end{tabular}


Table 10 - RAAU use of substrates ranked by strength and complexity

\begin{tabular}{|c|c|c|c|c|c|c|c|}
\hline Species & $\begin{array}{l}\text { Strength } \\
\text { Ranking }\end{array}$ & $\begin{array}{l}\text { Structural } \\
\text { Complexity }\end{array}$ & Substrate Species & $\begin{array}{c}\text { Number of } \\
\text { Ponds } \\
\text { Analyzed }\end{array}$ & $\begin{array}{c}\text { Usage } \\
\text { more than } \\
\text { expected }\end{array}$ & $\begin{array}{l}\text { Usage } \\
\text { less than } \\
\text { expected }\end{array}$ & $\begin{array}{c}\text { Random } \\
\text { Use }\end{array}$ \\
\hline \multirow{5}{*}{ RAAU } & 5 & $\overline{1}$ & Reed Canarygrass & 5 & 3 & 0 & 2 \\
\hline & 2 & 2 & Hardhack & 3 & 1 & 2 & 0 \\
\hline & 3 & 3 & Sedge & 4 & 1 & 1 & 2 \\
\hline & 4 & 4 & Waterpepper & 4 & 1 & 2 & 1 \\
\hline & 1 & 5 & Willow & 4 & 1 & 2 & 1 \\
\hline
\end{tabular}

Table 11 - AMGR use of substrates ranked by strength and complexity

\begin{tabular}{|c|c|c|c|c|c|c|c|}
\hline \multirow{3}{*}{ Species } & $\begin{array}{c}\text { Strength } \\
\text { Ranking }\end{array}$ & $\begin{array}{c}\text { Structural } \\
\text { Complexity }\end{array}$ & Substrate Species & $\begin{array}{c}\text { Number of } \\
\text { Ponds } \\
\text { Analyzed }\end{array}$ & $\begin{array}{c}\text { Usage } \\
\text { more than } \\
\text { expected }\end{array}$ & $\begin{array}{c}\text { Usage } \\
\text { less than } \\
\text { expected }\end{array}$ & $\begin{array}{c}\text { Random } \\
\text { Use }\end{array}$ \\
\hline \multirow{5}{*}{ AMGR } & 5 & 1 & Reed Canarygrass & 3 & 1 & 0 & 2 \\
\cline { 2 - 8 } & 2 & 2 & Hardhack & 2 & 0 & 1 & 1 \\
\cline { 2 - 8 } & 3 & 3 & Sedge & 2 & 1 & 1 & 0 \\
\cline { 2 - 8 } & 4 & 4 & Waterpepper & 3 & 1 & 0 & 2 \\
\hline
\end{tabular}

Table 12 - HYRE use of substrates ranked by strength and complexity

\begin{tabular}{|c|c|c|c|c|c|c|c|}
\hline & $\begin{array}{c}\text { Strength } \\
\text { Ranking }\end{array}$ & $\begin{array}{c}\text { Structural } \\
\text { Complexity }\end{array}$ & Substrate Species & $\begin{array}{c}\text { Number of } \\
\text { Ponds } \\
\text { Analyzed }\end{array}$ & $\begin{array}{c}\text { Usage } \\
\text { more than } \\
\text { expected }\end{array}$ & $\begin{array}{c}\text { Usage } \\
\text { less than } \\
\text { expected }\end{array}$ & $\begin{array}{c}\text { Random } \\
\text { Use }\end{array}$ \\
\hline \multirow{3}{*}{ HYRE } & 5 & 1 & Reed Canarygrass & 2 & 2 & 0 & 0 \\
\cline { 4 - 8 } & 2 & 2 & Hardhack & 0 & 0 & 0 & 0 \\
\cline { 4 - 8 } & 3 & 3 & Sedge & 1 & 0 & 1 & 0 \\
\cline { 4 - 8 } & 4 & 4 & Waterpepper & 1 & 0 & 1 & 0 \\
\hline
\end{tabular}

Table 13 - AMMA use of substrates ranked by strength and complexity

\begin{tabular}{|c|c|c|c|c|c|c|c|}
\hline & $\begin{array}{c}\text { Strength } \\
\text { Ranking }\end{array}$ & $\begin{array}{c}\text { Structural } \\
\text { Complexity }\end{array}$ & Substrate Species & $\begin{array}{c}\text { Number of } \\
\text { Ponds } \\
\text { Analyzed }\end{array}$ & $\begin{array}{c}\text { Usage } \\
\text { more than } \\
\text { expected }\end{array}$ & $\begin{array}{c}\text { Usage } \\
\text { less than } \\
\text { expected }\end{array}$ & $\begin{array}{c}\text { Random } \\
\text { Use }\end{array}$ \\
\hline & 5 & 1 & Reed Canarygrass & 2 & 2 & 0 & 0 \\
\cline { 4 - 8 } & 2 & 2 & Hardhack & 0 & 0 & 0 & 0 \\
\cline { 4 - 8 } & 3 & 3 & Sedge & 1 & 0 & 1 & 0 \\
\cline { 4 - 8 } & 4 & 4 & Waterpepper & 1 & 0 & 1 & 0 \\
\hline
\end{tabular}




\section{Cover Hypothesis}

Mapping analysis revealed variation in vegetation cover types around pond margins and amphibian egg mass distribution (Appendix $\mathrm{K}$ shows individual pond maps). Tree cover around each pond ranged from $0 \%$ (Butterfly) to $76 \%$ (Pancreas)(Figure 18). Shrub cover ranged from 0\% (Butterfly and Kidney) to $48 \%$ (Spirea), whereas herbaceous vegetated margins ranged from $13 \%$ (Spirea) to $100 \%$ (Butterfly) (Figure 18). In the nearest edge analysis of the distribution of northern red-legged frog egg masses, $0-89 \%$ of the egg masses were nearest tree cover, $0-80 \%$ were nearest shrubs, and $0-100 \%$ were nearest herbaceous cover (Figure 18). Comparison the percent of each cover type available to the nearest egg mass distribution percentages showed no significant differences (Table 14). Nearest edge analysis for northwestern salamander in Kidney, Pancreas and Sedge Ponds showed egg masses associated with tree cover $9-100 \%$, shrub cover $0-$ $40 \%$, and herbaceous cover $0-91 \%$ (Figure 18 ). Similarly, no significant relationship was found between the distribution of the northwestern salamander eggs and available cover types.

Vegetation cover immediately around northern red-legged frogs and northwestern salamanders was also examined (Table 15). Vegetation cover around northern red-legged egg masses ranged from 10\% (Pancreas) to $90 \%$ (Spirea). Northwestern salamander egg masses were found in vegetation cover ranging from 
$5 \%$ (Kidney) to $60 \%$ (Sedge). Percent cover of vegetation around egg masses with reed canarygrass averaged $56 \%$, whereas similar cover around egg masses with hardhack was $77 \%, 43 \%$ for sedge, $48 \%$ for willow, and $23 \%$ for water pepper (Table 15). The distribution of vegetation cover within $15 \mathrm{~cm}$ of the egg masses was significantly different between northern red-legged frog and northwestern salamander (Figure 19).

The correlation analysis between the number of egg masses and the percentage of the three cover types and cover type combinations within and around the ponds showed no significant relationship (Table 16). However, when the marginal vegetation category analyzed as $<50 \%$ tree and shrub cover versus $\geq 50 \%$ tree and shrub cover was compared to a high $(\mathrm{n} \geq 10)$ versus low $(\mathrm{n}<10)$ number of northern red-legged frog egg masses, all ponds with few egg masses $(n=2)$ were in the lower tree and shrub cover category, whereas all ponds with many egg masses $(n=10)$ were in the high tree and shrub cover category. This result is significant (Fisher's exact test: $\mathrm{df}=1, \chi^{2}=7.00, \mathrm{p}=0.0082$ ). The parallel analysis done with within-pond vegetation did not show a significant result. Too few ponds had northwestern salamander present to do a parallel analysis for that species. 
Figure 18 - Oviposition versus cover around pond edges for the northern red-legged frog and northwestern salamander

In the two subsequent graphs, "Eggs" on the $\mathrm{x}$ axis represent the percentages of pond margin vegetation in each structural category closest to egg masses; "Edge" represents the actual percentages of pond margin vegetation in each structural category.
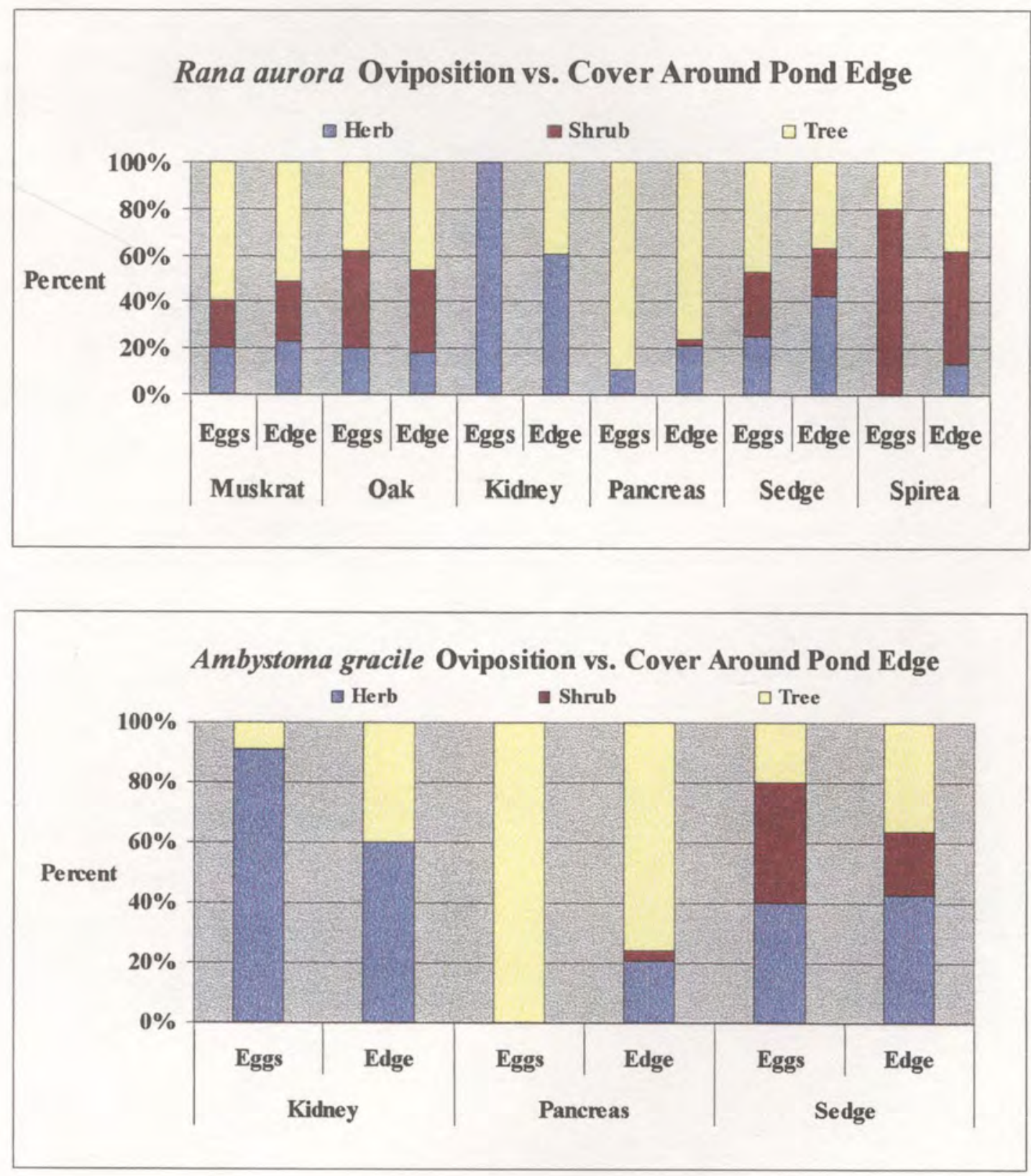
Table 14 - Egg mass distribution versus pond edge cover, 2000 reproductive season The following two tables describe the Chi-square analysis comparing the percentages of pond margin vegetation associated with egg masses versus pond margin vegetation available. Both of the latter are depicted in Figure 18.

\begin{tabular}{|c|c|c|c|}
\hline \multicolumn{4}{|c|}{ RAAU } \\
\hline Pond & $\begin{array}{l}\text { Vegetation } \\
\text { Category }\end{array}$ & Chi-square Value & Significance \\
\hline \multirow{3}{*}{ Muskrat } & Herb & 0.06 & \\
\hline & Shrub & 0.29 & \\
\hline & Tree & 0.30 & \\
\hline \multirow{3}{*}{ Oak } & Herb & 0.36 & \\
\hline & Shrub & 1.13 & \\
\hline & Tree & 1.70 & \\
\hline \multirow{3}{*}{ Pancreas } & Herb & 0.92 & \\
\hline & Shrub & 0.64 & \\
\hline & Tree & 0.44 & \\
\hline \multirow{3}{*}{ Sedge } & Herb & 2.56 & \\
\hline & Shrub & 0.78 & \\
\hline & Tree & 1.10 & \\
\hline \multirow{3}{*}{ Spirea } & Herb & 1.34 & \\
\hline & Shrub & 2.10 & \\
\hline & Tree & 0.88 & \\
\hline
\end{tabular}

\begin{tabular}{|c|l|c|c|}
\hline \multicolumn{2}{|c|}{ AMGR } & Significance \\
\hline \multirow{3}{*}{ Pond } & $\begin{array}{l}\text { Vegetation } \\
\text { Category }\end{array}$ & Chi-Square & \\
\hline \multirow{3}{*}{ Pancreas } & Herb & 1.73 & \\
\cline { 2 - 4 } & Shrub & 0.00 & \\
\cline { 2 - 4 } & Tree & 2.62 & $*$ \\
\hline \multirow{3}{*}{ Sedge } & Herb & 4.10 & \\
\cline { 2 - 4 } & Shrub & 0.67 & \\
\cline { 2 - 4 } & Tree & 1.50 & \\
\hline & Herb & 0.01 & \\
\hline & Shrub & 0.86 & \\
\hline & Tree & 0.38 & \\
\hline
\end{tabular}


Table 15 - Percentage of aquatic vegetation cover around egg masses, 2000 reproductive season Percent vegetation refers to cover within $15 \mathrm{~cm}$ of individual egg masses.

\begin{tabular}{|c|c|c|c|c|c|c|}
\hline Pond & Amphibian & Sample & Substrate & \multicolumn{3}{|c|}{ Percent Vegetation } \\
\cline { 4 - 7 } & Species & Size & & Range & Mean & Mode \\
\hline \multirow{3}{*}{ Kidney } & AMGR & 9 & PHAR & $<5-50$ & 19 & 5 \\
\cline { 2 - 7 } & AMGR & 6 & PO.sp & $5-90$ & 20 & 5 \\
\cline { 2 - 7 } & RAAU & 2 & PHAR & $5-25$ & 15 & $*$ \\
\hline \multirow{3}{*}{ Muskrat } & RAAU & 7 & PHAR & $30-50$ & 41 & 80 \\
\cline { 2 - 7 } & RAAU & 14 & PO.sp & $20-90$ & 53 & 50 \\
\hline \multirow{3}{*}{ Oak } & AMGR & 3 & PHAR & $75-90$ & 83 & $*$ \\
\cline { 2 - 7 } & RAAU & 108 & PHAR & $10-95$ & 62 & 80 \\
\cline { 2 - 7 } & RAAU & 7 & SALA & $20-75$ & 50 & 20 \\
\hline \multirow{5}{*}{ Pancreas } & AMGR & 12 & PHAR & $10-80$ & 32 & 10 \\
\cline { 2 - 7 } & AMGR & 7 & PO.sp & $5-20$ & 11 & 10 \\
\cline { 2 - 7 } & RAAU & 1 & CAOB & $<5$ & $*$ & $*$ \\
\cline { 2 - 7 } & RAAU & 8 & PHAR & $15-60$ & 34 & 20 \\
\cline { 2 - 7 } & RAAU & 4 & PO.sp & $<5-10$ & 9 & 10 \\
\hline \multirow{3}{*}{ Sedge } & AMGR & 5 & PHAR & $40-60$ & 56 & 60 \\
\cline { 2 - 7 } & RAAU & 1 & CAOB & 80 & $*$ & $*$ \\
\cline { 2 - 7 } & RAAU & 32 & PHAR & $10-90$ & 55 & 50 \\
\hline \multirow{3}{*}{ Spirea } & RAAU & 7 & PHAR & $30-90$ & 72 & 90 \\
\cline { 2 - 7 } & RAAU & 4 & SPDO & $60-90$ & 77 & $*$ \\
\hline
\end{tabular}

*Indicates too few values existed to generate mode 
Figure 19 - Variation in percent cover around oviposition sites for the northern red-legged frog and northwestern salamander.

Analysis of the means revealed significant differences in the mean percent cover found around the egg masses of each species $(z=-4.955$, df $=1, p<0.0001)$.

Frequency Distribution of Cover Within $15 \mathrm{~cm}$ of Egg Masses

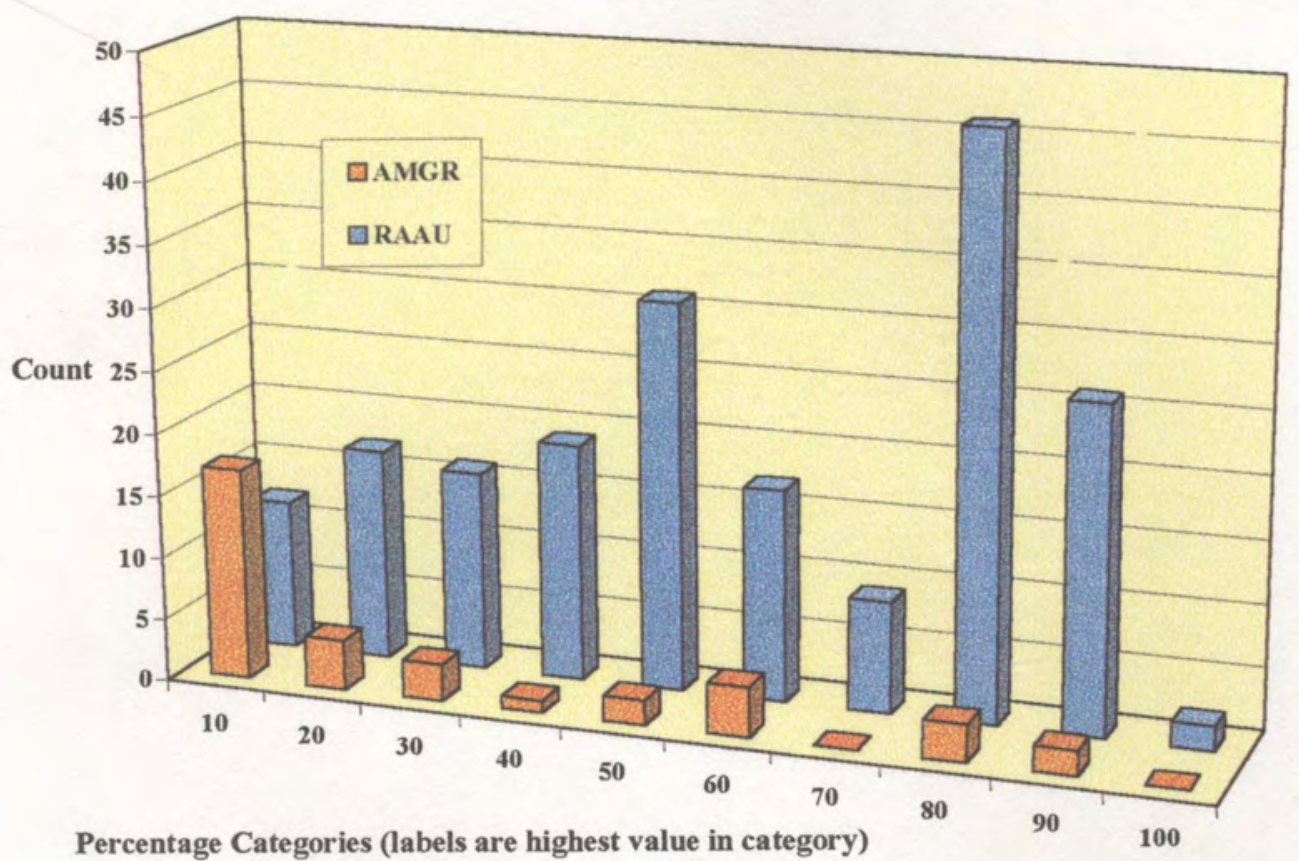


Table 16 - Relationship of number of northern red-legged frogs egg masses and vegetation cover, 2000 reproductive season

\begin{tabular}{|c|c|c|c|}
\hline & Comparison & $\begin{array}{c}\text { Spearmans } \rho \\
\text { Correlation } \\
\text { Coefficient }\end{array}$ & $\begin{array}{c}\text { Significance } \\
\text { Level }\end{array}$ \\
\hline \multirow{4}{*}{$\begin{array}{c}\text { Vegetation in } \\
\text { Pond }\end{array}$} & Herb & -0.523 & 0.229 \\
\cline { 2 - 4 } & Shrub & 0.111 & 0.812 \\
\cline { 2 - 4 } & Tree & 0.433 & 0.331 \\
\cline { 2 - 4 } & Tree/Shrub & 0.523 & 0.201 \\
\cline { 2 - 4 } & Herb/shrub & -0.433 & 0.331 \\
\hline \multirow{3}{*}{$\begin{array}{c}\text { Vegetation } \\
\text { Margin }\end{array}$} & Herb & -0.500 & 0.253 \\
\cline { 2 - 4 } & Shrub & 0.595 & 0.159 \\
\cline { 2 - 4 } & Tree & 0.393 & 0.383 \\
\cline { 2 - 4 } & Tree/Shrub & 0.500 & 0.221 \\
\cline { 2 - 4 } & Herb/Shrub & -0.393 & 0.383 \\
\hline
\end{tabular}

\begin{tabular}{|l|c|c|c|c|c|}
\hline \multicolumn{7}{|c|}{$\begin{array}{l}\text { Within Pond Percent Cover } \\
\text { (From Pond Vegetation Avail Data) }\end{array}$} \\
\hline Pond & RAAU (n) & Herb & Tree & Shrub & sum \\
\hline Butterfly & 2 & 100.0 & 0 & 0 & 100.0 \\
\hline Kidney & 3 & 100.0 & 0 & 0 & 100.0 \\
\hline Muskrat & 20 & 99.9 & 0 & 0.1 & 100.0 \\
\hline Oak & 118 & 97.0 & 3 & 0 & 100.0 \\
\hline Pancreas & 19 & 97.7 & 0.4 & 1.9 & 100.0 \\
\hline Sedge & 36 & 98.9 & 0 & 1.1 & 100.0 \\
\hline Spirea & 10 & 90.3 & 0.1 & 9.6 & 100.0 \\
\hline \multicolumn{5}{|c|}{ Pond Margin Percent Cover } \\
\hline Pond & (From Mapping Analysis) & & \\
\hline Butterfly & RAAU (n) & Herb & Tree & Shrub & sum \\
\hline Kidney & 2 & 100.0 & 0 & 0 & 100.0 \\
\hline Muskrat & 3 & 60.0 & 40 & 0 & 100.0 \\
\hline Oak & 20 & 23.0 & 51 & 26 & 100.0 \\
\hline Pancreas & 118 & 18.0 & 46 & 36 & 100.0 \\
\hline Sedge & 19 & 21.0 & 76 & 3 & 100.0 \\
\hline Spirea & 36 & 42.0 & 37 & 21 & 100.0 \\
\hline
\end{tabular}




\section{Invertebrate and Fish Species Composition}

Details of invertebrate sweep net surveys and the minnow trapping are provided in Appendices L and M. Some water column invertebrates (e.g., fairy shrimp and mayflies) were positively correlated with the abundance of northwestern salamander egg masses (Appendix L), so invertebrate abundance could explain the greater numbers of northwestern salamander egg masses in some study ponds. Microcrustacean invertebrates are known to be a key food source for young ambystomatid salamanders (Anderson 1967, Efford and Mathias 1969), and may be limiting northwestern salamander use of some ponds.

Since few fish were observed or sampled (Appendix M) and the lowest egg mass numbers were not from ponds in which the fish were found, I had no evidence that fish presence might be limiting oviposition.

\section{Water Quality Data}

The five water quality variables (temperature, $\mathrm{pH}$, dissolved oxygen, depth, and turbidity) measured ranged widely both among and within ponds over time (Appendix N). A repeated measures ANOVA showed that all water quality variables differed significantly among the five ponds over time (Table 17). Figure 20 depicts the variation in the five water quality variables. None of the water 
quality variables indicated conditions that might limit or deter amphibian oviposition in the study ponds.

Table 17 - Comparison of water quality variables among pond, February-April 2000 All tests in the following comparison were significant at $P<0.001$.

\begin{tabular}{|c|c|c|c|}
\hline \multirow{2}{*}{$\begin{array}{c}\text { Water Quality } \\
\text { Variable }\end{array}$} & Time & Pond & $\begin{array}{c}\text { Time * Pond } \\
\text { Interaction }\end{array}$ \\
\cline { 2 - 4 } & (df 2) & (df 4) & (df 8) \\
\hline pH & 52 & 59 & 5 \\
\hline Temperature & 3380 & 257 & 102 \\
\hline Turbidity & 9 & 24 & 6 \\
\hline Dissolved Oxygen & 37 & 86 & 13 \\
\hline Depth & 30 & 15 & 11 \\
\hline
\end{tabular}


Figure 20 - Water quality
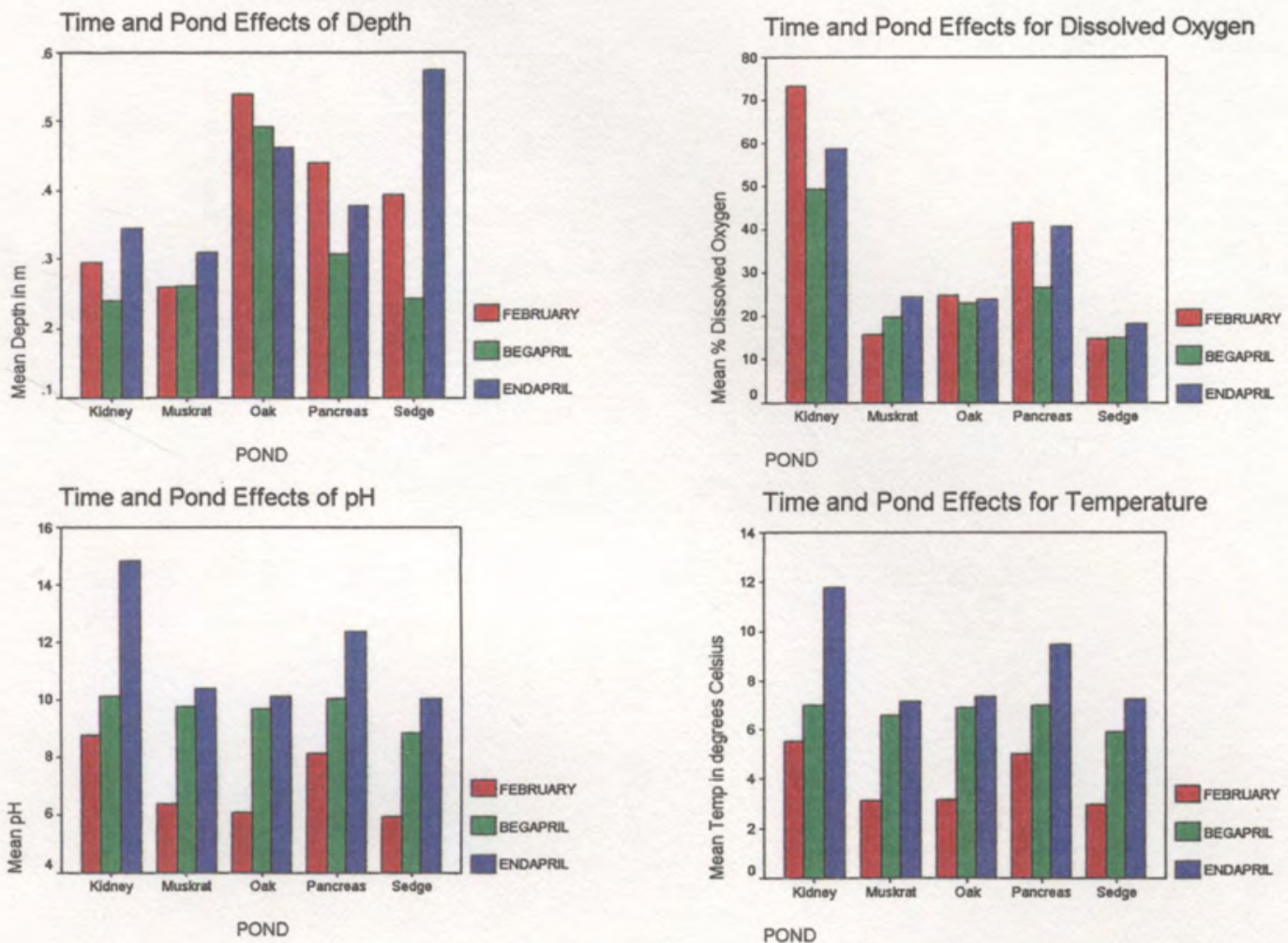

\section{Time and Pond Effects for Temperature}
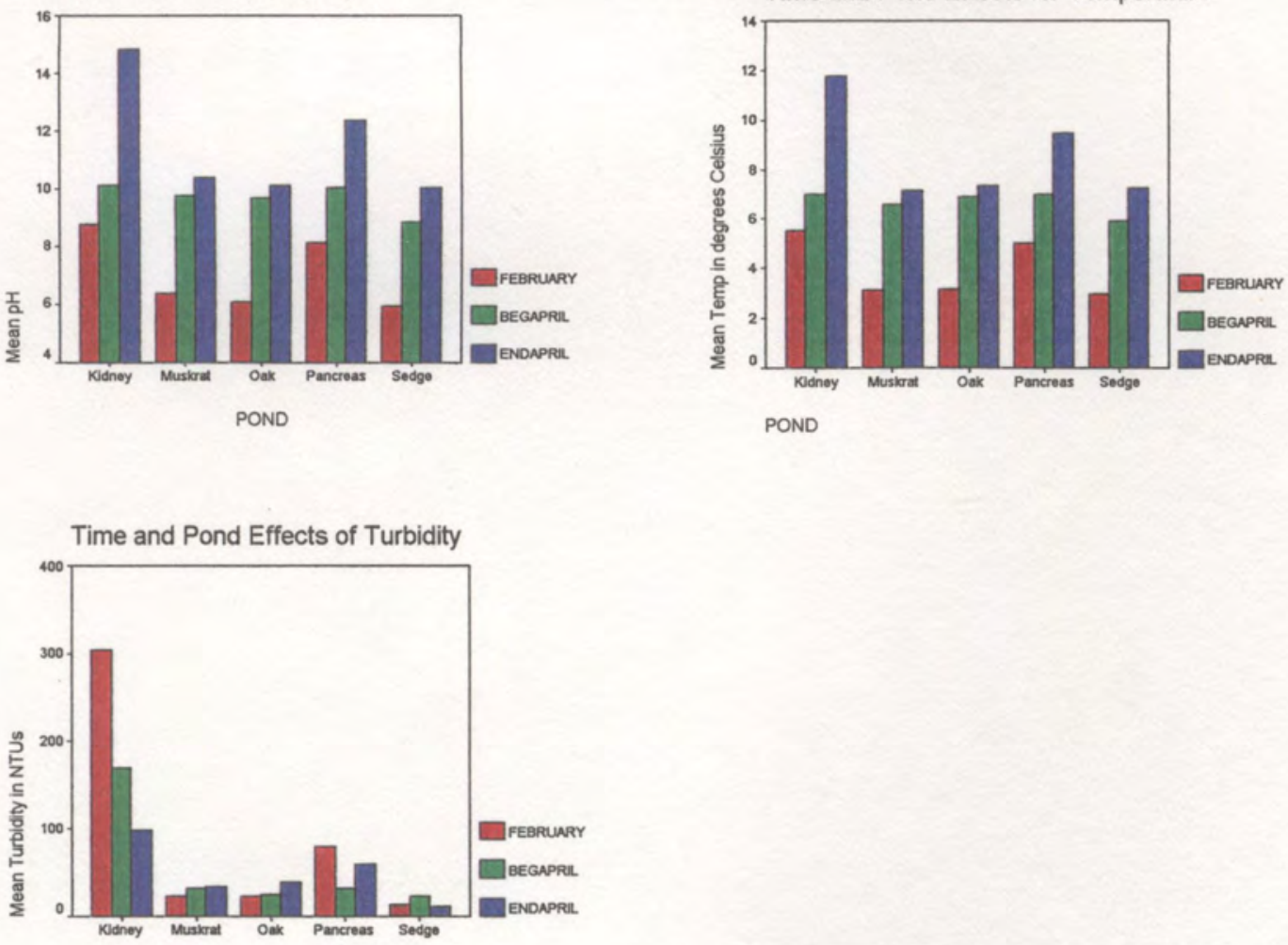

POND 


\section{Discussion}

\section{Vegetation}

I was unable to consistently reject the directional null hypothesis that amphibians used native vegetation for oviposition at frequencies equal or greater than that of the exotic species present. I was able to reject this hypothesis in three ponds (Oak, Sedge, and Muskrat), but I failed to reject it in the remaining four (Table 6). Lack of consistent rejection indicates that vegetation status (i.e., exotic versus native) is likely not important in selecting an oviposition brace.

As exotic vegetation was often used more frequently than expected, and the dominant exotic species was reed canarygrass, I chose to examine the possibility that reed canarygrass and alternative oviposition substrates might differ in strength as a basis for amphibian selection of an oviposition brace.

\section{Substrate Strength}

The different vegetation braces used for oviposition differed significantly in overall strength. However, egg masses were not found with significantly greater frequency on stronger braces (Tables 10-13). I found no evidence to conclude that substrate strength, at least as I measured it, might be the basis for selecting of an oviposition substrate. 


\section{Cover}

The most frequently used substrate, reed canarygrass, also differed in structure from the other brace species in having a more complex growth form (i.e., complex of radiating leaves on closely spaced stems). Stronger woody-stemmed species, such as hardhack and willow, were much less abundant or less complex. Sedge, like reed canarygrass, grows as a relatively dense vertical structure, but has a more limited lateral complexity. Water pepper has some lateral complexity, but typically spreads out more horizontally over the water surface, and has less of an emergent component than reed canarygrass.

Analysis taking structural complexity of each plant species into account did reveal significant patterns of use among plant species with differences in complexity (Tables 10-13). The rankings were based on visual observations and not actual measurements, but did provide a comparison between species. Structural complexity relates to local cover density. Egg masses and ovipositing adults may be more concealed, and thus, protected from predators in more complex vegetation. More refined examination of this idea, especially with experimental manipulation, is needed to determine whether this pattern is consistent.

Distribution of the egg masses of both northern red-legged frogs and northwestern salamanders within the ponds seemed somewhat clumped, but the nearest edge analysis did not reveal any significant associations between egg masses and the structural types of edge vegetation (Table 14). Nonetheless, the 
mapping analysis revealed that the ponds with the most red-legged egg masses (i.e., $>10$ ) all had $\geq 50 \%$ marginal shrub and tree cover (Figure 18).

Reed canarygrass was the most abundant species providing dense cover when all ponds were considered. Northern red-legged frog egg masses were found more frequently in vegetation providing denser cover than northwestern salamander egg masses, therefore, they were frequently found in reed canarygrass. This difference may reflect differences in vulnerability resulting from differences in mating and oviposition behavior between the two species.

I found no significant correlation between the number of red-legged frog egg masses and the amount of cover within the pond. However, one might not expect such a relationship if certain threshold-cover conditions are required. A refined sampling approach may yet reveal such a pattern, and my finding that northern red-legged frogs showed greater oviposition in ponds with greater cover would seem to agree with this idea. Northern red-legged frog need for cover may be linked to their seasonal movements from densely vegetated upland habitats (active season, non-breeding) to aquatic habitats (breeding). Several studies have suggested that northern red-legged frogs may be cover sensitive, and a shrub or similar low structural matrix may be important (Aubry 1997, Ritson and Hayes 2000). More northwestern salamanders were found in the larger ponds, which also had a greater percentage of tree/shrub cover available, but the sample size was small. Other studies on amphibian reproductive sites have correlated reproduction 
mainly with emergent vegetation (Monella and Wright 1999,)Thompson et al. 1980). However, the significance of emergent vegetation as an oviposition brace versus its ability to provide cover to egg-laying amphibians has typically not been distinguished. Therefore, significant association between egg mass distribution and emergent vegetation may yet be revealed through examination of vegetation density with careful attention to scale.

\section{Other Habitat factors}

Lack of relationship between egg mass numbers and different water quality variables suggests that the water quality variables may not influence oviposition over the range of conditions measured. Likewise, lack of relationship to fish suggests that fish were not important to oviposition in the systems examined. However, selection of those systems may be occurring because they are fish poor, a condition that has been repeatedly demonstrated elsewhere (e.g., Kats and Sih 1992, Holomuzki 1995). However, the pond sample sizes being small, water quality conditions being relatively benign, and fish presence being limited likely all restricted my ability to recognize water quality or fish effects, even if these existed. I would anticipate that conditions with more abundant fishes or more extreme water quality parameters might significantly influence oviposition.

The only other habitat factor I measured implying that a constraint on pond use might exist was water column invertebrates, the abundance of which was 
correlated with abundance of northwestern salamander egg masses. Further investigation would be needed to determine just how water column invertebrates and oviposition conditions might be confounded for the northwestern salamander.

\section{Implications and Conclusions}

The original focus of this study was to examine whether exotic vegetation might be less favorable for oviposition among stillwater-breeding amphibians. My data suggest that vegetation status (exotic or native), at least in the manner I measured it, does not seem to influence selection of oviposition sites. Similarly, strength of the oviposition brace seems unrelated to oviposition site selection. The one factor that may play a role in oviposition site selection is the cover characteristics of the oviposition substrate. My seemingly inconsistent results related to vegetation cover, either at the level of oviposition substrate or where the oviposition site is located within the pond, may arise from several factors. Species response to cover may differ. My data showed that northern red-legged frogs selected oviposition sites that with significant more near-space cover than northwestern salamanders. This pattern needs further verification. If true, it is unclear whether denser cover close to the oviposition site is an advantage to ovipositing adults, to developing embryos in the egg mass, or both. Moreover, other studies have shown that northern red-legged frogs are highly crypsis dependent (Ritson and Hayes 2000), and in terrestrial habitats appear to be dependent on a complex, low structural matrix for cover (e.g., ferns: Aubry 1997). 
Failure to demonstrate that marginal cover characteristic of the study ponds were spatially related to oviposition patterns may mean the cover characteristics of the aquatic habitat are unimportant for northern red-legged frogs. Alternatively, it may mean that either I did not measure the appropriate cover metric or measure cover at the appropriate scale. In either case, further investigation of cover is warranted. 


\section{Literature Cited}

Adams, M.J. 1999. Correlated factors in amphibian decline: Exotic species and habitat change in western Washington. Journal of Wildlife Management 63(4):1162-1171.

Aubry, K.B. 1997. Chapter 2: Influence of stand structure and landscape composition on terrestrial amphibians. Volume 2: Wildlife Use of Managed Forests: A Landscape Perspective. TFW report to the Washington Department of Natural Resource. K.B. Aubry, S.D. West, D.A. Manual, A.B. Stringer, J.L. Erickson and S. Pearson. 2:1-43.

Anderson, J.D. 1967. A comparison of the life histories of coastal and montane populations of Ambystoma macrodactylum in California. American Midland Naturalist 77:323-355.

Awbrey, F.T. 1978. Social interaction among chorusing Pacific treefrogs, Hyla regilla. Copeia 1978(2):208-214.

Beebee, T.J.C. 1996. Ecology and conservation of amphibians. Chapman \& Hall, London. .

Berger, L., R. Speare, P. Daszak, D.E. Green, A.A. Cunningham, C.L. Goggin, R. Slocombe, M.A. Ragan, A.D. Hyatt, K.R. McDonald, H.B. Hines, K.R. Lips, G. Marantelli, and H. Parkes. 1998. Chytridiomycosis causes amphibian mortality associated with population declines in the rain forests of Australia and Central America. Proceedings of the National Academy of Sciences (USA) 95:9031-9036.

Blaustein, A.R., D.G. Hokit, R.K. O'Hara and R.A. Holt. 1994. Pathogenic fungus contributes to amphibian losses in the Pacific Northwest. Biological Conservation 67(3):251-254.

Blaustein, A.R., J.M. Kiesecker and D.G. Hokit. 1995. Amphibian declines and UV radiation. BioScience 45(Sept. '95):514-515. 
Blaustein, A.R. and D.B. Wake. 1990. Declining amphibian populations: A global phenomenon? Trends in Ecology and Evolution 5(7):203-204.

Bosch, J., I. Martinez-Solano, and M. Garcia-Paris. 2001. Evidence of a chytrid fungus infection involved in the decline of the common midwife toad (Alytes obstetricans) in protected areas of central Spain. Biological Conservation 97:331-337.

Brenowitz, E.A. and G.J. Rose. 1999. Female choice and plasticity of male calling behaviour in the Pacific treefrog. Animal Behaviour 57:1337-1342.

Brown, H.A. 1975. Reproduction and development of the red-legged frog, Rana aurora, in northwestern Washington. Northwest Science 49(4):241-252.

Brown, H.A. 1976. The time-temperature relation of embryonic development in the northwestern salamander, Ambystoma gracile. Canadian Journal of Zoology 54:552-558.

Chown, S.L. and W. Block. 1997. Comparative nutritional ecology of grassfeeding in a sub-Antarctic beetle: the impact of introduced species on Hydromedion sparsutum from South Georgia. Oecologia 111(July '97 pt 1):216-224 bibl il.

Cooke, S.S. 1997. A field guide to the common wetland plants of Western Washington and Northwestern Oregon. Seattle Audubon Society, Seattle.

Corkran, C.C. and C. Thoms. 1996. Amphibians of Oregon, Washington and British Columbia: A field Identification guide. Lone Pine Publishing, Renton.

Corn, P.S. 1994. What we know and don't know about amphibian declines in the West. In: Sustainable Ecological Systems: Implementing an Ecological Approach to Land Management. U.S. Forest Service General Technical Report 247:59-67. 
Delis, P.R., H.R. Mushinsky and McCoy, E.D. 1996. Decline of some west-central Florida anuran populations in response to habitat degradation. Biodiversity \& Conservation 5(12):1579-1595.

Duellman, W.E. and L. Trueb. 1994. Biology of amphibians. Johns Hopkins University Press, Baltimore.

Eagleson, G.W. 1976. A comparison of the life histories and growth patterns of populations of the salamander Ambystoma gracile (Baird) from permanent low-altitude and montane lakes. Canadian Journal of Zoology 54:20982111.

Efford, I.E. and J.A. Mathias. 1969. A comparison of two salamander populations in Marion Lake, British Columbia. Copeia 1969(4):723-735.

Fernberg, L.S. and J.D. Wehr. 1995. Growth interactions and effects of exotic and native wetland plants on detrital pathways and nutrient cycling in freshwater Hudson River wetlands. Northeast Conference on Nonindigenous Aquatic Nuisance Species, Cromwell, Connecticut.

Figiel, C.R.J. and R.D. Semlitsch. 1995. Experimental determination of oviposition site selection in the marbled salamander, Ambystoma opacum. Journal of Herpetology 29(3):452-454.

Fukumoto, J. and S. Herrero. 1998. Observations of the long-toed salamander, Ambystoma macrodactylum, in Waterton Lakes National Park, Alberta. Canadian Field Naturalist 112(4):579-585.

Green, D.M. and R.W. Campbell. 1984. The amphibians of British Columbia. British Columbia Provincial Museum 45:1-101.

Grubb, J.C. 1972. Differential predation by Gambusia affinis on the eggs of seven species of anuran amphibians. The American Midland Naturalist 88(1):102-108. 
Guard, J.B. 1995. Wetland plants of Oregon and Washington. Lone Pine Publishing, Vancouver, British Columbia.

Hayes, M.P. and M.R. Jennings. 1986. Decline of ranid frog species in western North America: Are bullfrogs (Rana catesbeiana) responsible? Journal of Herpetology 20:490-509.

Hayes, M.P. and M.M. Miyamoto, 1984. Biochemical, behavioral, and body size differences between Rana aurora aurora and Rana aurora draytonii. Copeia1984(4):1018-1022.

Hitchcock, C.L. and A. Cronquist. 1973. Flora of the Pacific Northwest. University of Washington Press, Seattle.

Holland, C.C., J. Honea, S.E. Gwin and M.E. Kentula. 1995. Wetland degradation and loss in the rapidly urbanizing area of Portland, Oregon. Wetlands 15:336-345.

Holomuzki, J.R. 1995. Oviposition sites and fish deterrent mechanisms of two stream anurans. Copeia 1995(3):607-613.

Howard, R.D. 1978. The influence of male-defended oviposition sites on early embryo mortality in bullfrogs. Ecology 59(4): 789-798.

Howard, J. and R. Wallace. 1985. Life history characteristics of populations of the long-toed salamander (Ambystoma macrodactylum ) from different altitudes. American Midland Naturalist 113(2):361-373.

Jennings, M.R. and M.P. Hayes. 1985. Pre-1900 overharvest of California redlegged frogs (Rana aurora draytonii): The inducement for bullfrog (Rana Catesbeiana) introduction. Herpetologica 41(1):94-103.

Kats, L.B and A. Sih. 1992. Oviposition site selection and avoidance of fish by streamside salamanders (Ambystoma barbouri). Copeia 1992(3): 468-473. 
Kiesecker, J.M. and A.R. Blaustein. 1998. Effects of introduced bullfrogs and small mouthed bass on microhabitat use, growth, and survival of native Rana aurora. Conservation Biology 12(4):776-787.

Kiesecker, J.M. and A.R. Blaustein. 1997. Influences of egg laying behavior on pathogenic infection of amphibian eggs. Conservation Biology 11(1):214220.

Kiesecker, J.M., A.R. Blaustein and L.K. Belden. 2001. Complex causes of amphibian population declines. Nature 410(5 April 2001):681-683.

Lawler, S.P., D. Dritz, T. Strange and M. Holyoak. 1999. Effects of introduced mosquitofish and bullfrogs on the threatened California red-legged frog. Conservation Biology 13(3):613-622.

Leonard, W.P. and K.O. Richter. 1994. Western long-toed salamander demographics and oviposition in a small vernal wetland of the Puget Sound lowlands. $67^{\text {th }}$ Annual Meeting of the Northwest Scientific Association, Ellensburg, Washington (USA), 23-26 Mar 1994, Northwest Science.

Licht, L.E. 1969. Unusual aspects of anuran sexual behavior as seen in the redlegged frog, Rana aurora aurora. Canadian Journal of Zoology 47(4):505509.

Licht, L.E. 1971. Breeding habits and embryonic thermal requirements of the frogs, Rana aurora aurora and Rana pretiosa pretiosa, in the Pacific Northwest. Ecology 52(1):116-124.

Licht, L.E. 1975. Growth and food of larval Ambystoma gracile from a lowland population in southwestern British Columbia. Canadian Journal of Zoology 53:1716-1722.

Licht, L.E. 1992. The effect of food level on growth rate and frequency of metamorphosis and paedomorphosis in Ambystoma gracile. Canadian Journal of Zoology 70(Jan. 1992): 87-93. 
MacDonald, I.A.W. and G.W. Frame. 1988. The invasion of introduced species into nature reserves in tropical savannas and dry woodlands. Biological Conservation 44(1-2):67-93.

Marco, A. and A.R. Blaustein. 2000. Symbiosis with green algae affects survival and growth of northwestern salamander embryos. Journal of Herpetology 34(4):617-621.

Marsh, D.M. and P.B. Pearman. 1997. Effects of habitat fragmentation on abundance of two species of leptodactylid frogs in an Andean Montane forest. Conservation Biology 11(6): 1323-1328.

Monella, R.J. and R.G. Wright. 1999. Amphibian habitat preferences among artificial ponds in the Palouse region of northern Idaho. Journal of Herpetology 33(2):298-303.

Moore, J.A. 1939. Temperature tolerance and rates of development in eggs of amphibia. Ecology 20:459-478.

Nussbaum, R.A., E.D. Brodie, Jr. and R.M. Storm. 1983. Amphibians and Reptiles of the Pacific Northwest. University Press of Idaho, Moscow, Idaho.

Olson, D.H., W.P. Leonard and R.B. Bury (editors). 1997. Sampling Amphibians in Lentic Habitats: Methods and Approaches for the Pacific Northwest. Northwest Fauna. Society for Northwestern Vertebrate Biology, Olympia, Washington.

Ovaska, K., T.M. Davis and I.N. Flamarique. 1997. Hatching success and larval survival of the frogs Hyla regilla and Rana aurora under ambient and artificially enhanced solar ultraviolet radiation. Canadian Journal of Zoology 75:1081-1088.

Pacific, W.H. 1993. Final Report: Burlington Bottoms Hydrology and Hydraulics Assessment prepared for The Oregon Department of Fish and Wildlife. Portland, Oregon. 
Pechmann, J.H.K., D.E. Scott, R.D. Semlitsch, J.P. Caldwell, L.J. Vitt and J.W. Gibbons. 1991. Declining amphibian populations: The problem of separating human impacts from natural fluctuations. Science 253:892-895.

Perrill, S.A. 1984. Male mating behavior in Hyla regilla. Copeia 1984(3):727732 .

Ramos, J.A. 1996. Introduction of exotic tree species as a threat to the Azores bullfinch population. The Journal of Applied Ecology 33(Aug 1996):710722 .

Resetarits, W.J., Jr. and H.M. Wilbur. 1989. Choice of oviposition site by Hyla chrysoscelis: Role of predators and competitors. Ecology 70(1):220-228.

Richter, K.O. and A.L. Azous. 1995. Amphibian occurence and wetland characteristics in the Puget Sound Basin. Wetlands 15(3):305-312.

Ritson, P.I. and M.P. Hayes. 2000. Late-season activity and overwintering in the northern red-legged frog (Rana aurora aurora). Final Report to the US Fish and Wildlife Service executed under Purchase Order 1448-13420-99-M166.

Rose, C. and W.G. Crumpton. 1996. Effects of emergent macrophytes on dissolved oxygen dynamics in a prairie pothole wetland. Wetlands 16(4):495-502.

Sjogren, P. 1991. Extinction and isolation gradients in metapopulations: The case of the pool frog (Rana lessonae). Biological Journal of the Linnean Society 42:135-147.

Skelly, D.K. 1996. Pond drying, predators and the distribution of Pseudacris tadpoles. Copeia 1996(3):599-605.

Smith, R.E. 1990. Comparison of the plant water relations of Cunonia capensis and Pittosporum undulatum in a riparian woodland in the south-western Cape, South Africa. South African Journal of Botany 56(3):409-412. 
Stebbins, R.C. and N.W. Cohen .1995. A natural history of amphibians. Princeton University Press, Princeton, New Jersey.

Stohlgren, T.J., D. Binkley, G.W. Chong, M.A. Kalkhan, L.D. Schell, K.A. Bull, Y. Otsuki, B. Newman, M. Bashkin and Y. Son. 1999. Exotic plant species invade hot spots of native plant diversity. Ecological Monographs 69(1):2546.

Storm, R.M. 1960. Notes on the breeding biology of the red-legged frog (Rana aurora aurora). Herpetologica 16(4):251-259.

Stromayer, K.A.K., R.J. Warren, A.S. Johnson, P.E. Hale, C.L Rogers, C.L. Tucker. 1998. Chinese privet and feeding ecology of white-tailed deer: The role of an exotic plant. Journal of Wildlife Management 62(4):1321-1329.

Sutherland, W.J. 1996. Ecological census techniques: a handbook. University Press, Cambridge.

Thompson, E.L., J.E. Gates and G.J. Taylor. 1980. Distribution and breeding habitat selection of the Jefferson salamander, Ambystoma jeffersonianum, in Maryland. Journal of Herpetology 14(2):113-120.

Trammell, M.A. and J.C. Butler. 1995. Effects of exotic plants on native ungulate use of habitat. Journal of Wildlife Management 59(4):808-816.

Tyler, T.J., W.J. Liss, R.L. Hoffman and L.M. Ganio. 1998. Experimental analysis of trout effects on survival, growth, and habitat use of two species of ambystomatid salamanders. Journal of Herpetology 32(3):345-349.

Verrell, P. and J. Pelton. 1996. The sexual strategy of the central long-toed salamander, Ambystoma macrodactylum columbiamum, in south-eastern Washington. Journal of Zoology 240(1):37-50.

Waring, G.L. and M. Tremble 1992. The impact of exotic plants on faunal diversity along a southwestern river. 1992 Annual Meeting of the 
Ecological Society of America, Honolulu, Hawaii, USA, August 9-13, 1992, Bulletin of the Ecological Society of America.

Wiens, J.A. 1970. Effects of early experience on substrate pattern selection in Rana aurora tadpoles. Copeia 1970(3):543-548.

Winpenny, R.S. 1951. The effect of vegetation on the breeding of newts, Molge cristata and Molge vulgaris. Journal of Animal Ecology 20:98-100.

Yavitt, J.B. and C.J. Williams. 1996. Methane dynamics and sediment respiration in a freshwater marsh invaded by native and exotic plant species. Bulletin of the Ecological Society of America 77(3 Supplement, Part 2):496.

Zweifel, R.G. 1968. Reproductive biology of anurans of the southwest with emphasis on adaptation of embryos to temperature. Bulletin of American Museum of Natural History 140:1-64.

Zweifel, R.G. 1977. Upper thermal tolerances of anuran embryos in relation to stage of development and breeding habits. American Museum Novitates 2617:1-20. 
80

\section{Appendices}

\section{Appendix A - Burlington Bottoms Oviposition Study 2000}
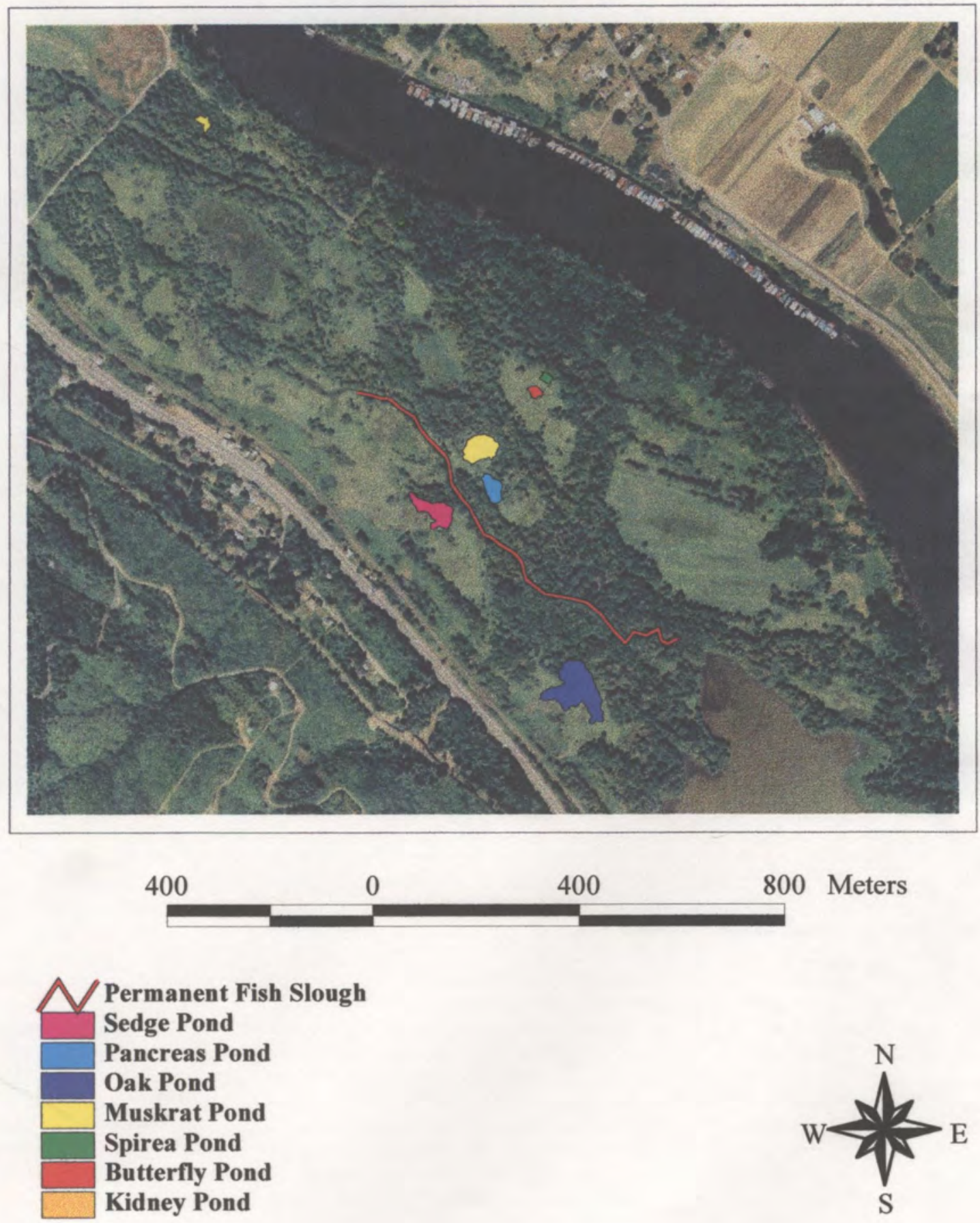
Callison: Factors Influencing Pond-breeding Amphibian Oviposition

Appendix B -- Vegetation Survey Effort

\begin{tabular}{|c|c|c|c|c|}
\hline \multirow{2}{*}{ Pond } & Dates & $\frac{\text { Effort }}{\mathbf{( h r} \text { ) }}$ & $\frac{\text { Number of }}{\text { \#People }}$ & $\begin{array}{c}\text { Effort } \\
\text { (person * hours) }\end{array}$ \\
\hline \multirow{2}{*}{ Oak } & $9 / 10 / 99$ & 3.0 & 2 & 6.0 \\
\cline { 2 - 5 } & $9 / 16 / 99$ & 2.0 & 2 & 4.0 \\
\hline \multirow{2}{*}{ Spirea } & $9 / 17 / 99$ & 1.0 & 2 & 2.0 \\
\hline \multirow{2}{*}{ Muskrat } & $9 / 17 / 99$ & 1.0 & 2 & 2.0 \\
\cline { 2 - 5 } & $9 / 24 / 99$ & 1.0 & 2 & 2.0 \\
\hline Kidney & $9 / 17 / 00$ & 1.0 & 2 & 2.0 \\
\hline Pancreas & $9 / 24 / 00$ & 1.5 & 2 & 3.0 \\
\hline Sedge & $9 / 24 / 00$ & 2.0 & 2 & 4.0 \\
\hline Totals & $10 / 1 / 99$ & 2.5 & 3 & 7.5 \\
\hline
\end{tabular}




\section{Appendix C: Survey Transects}

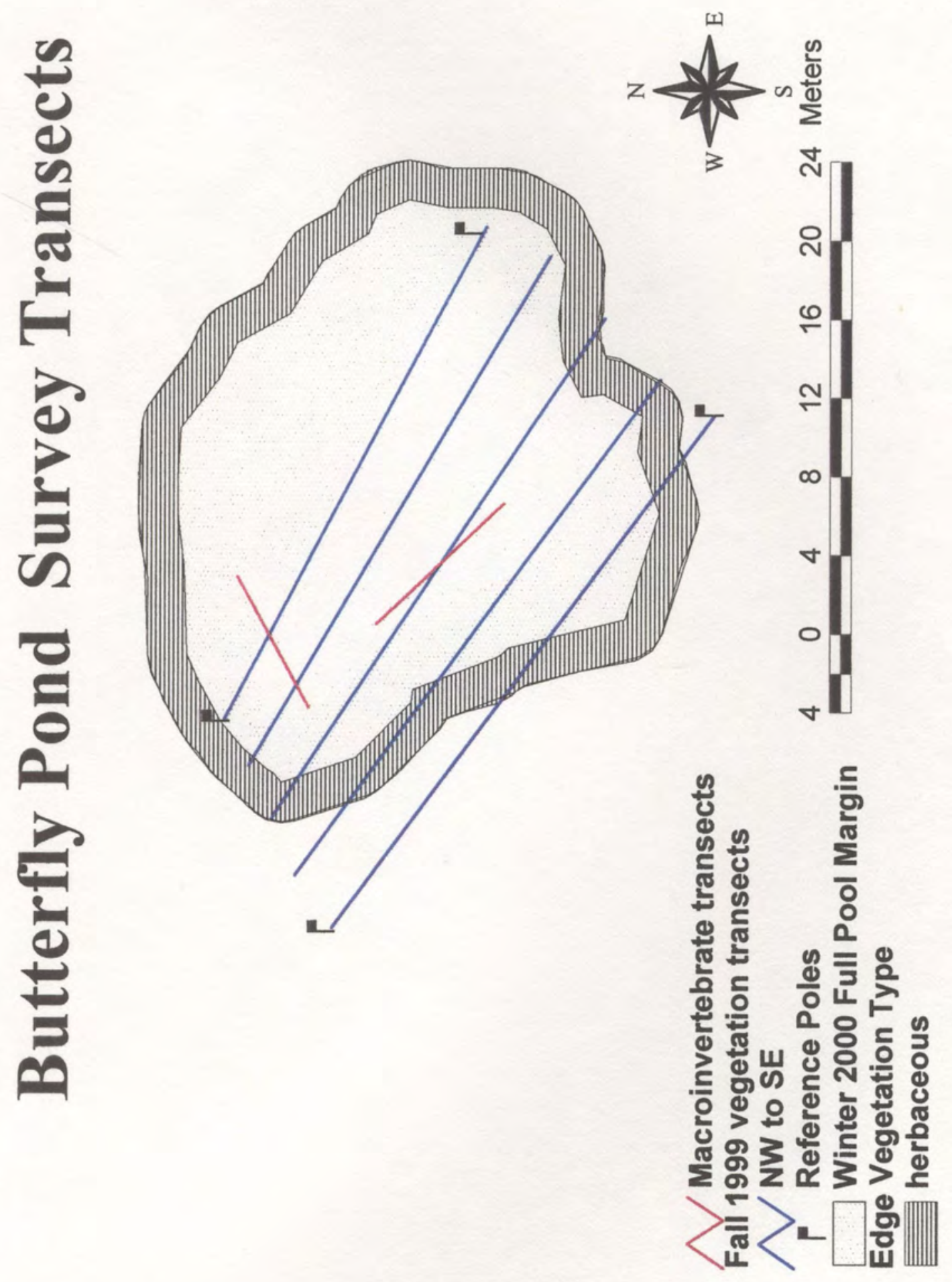




\section{Appendix C-Survey Transects}

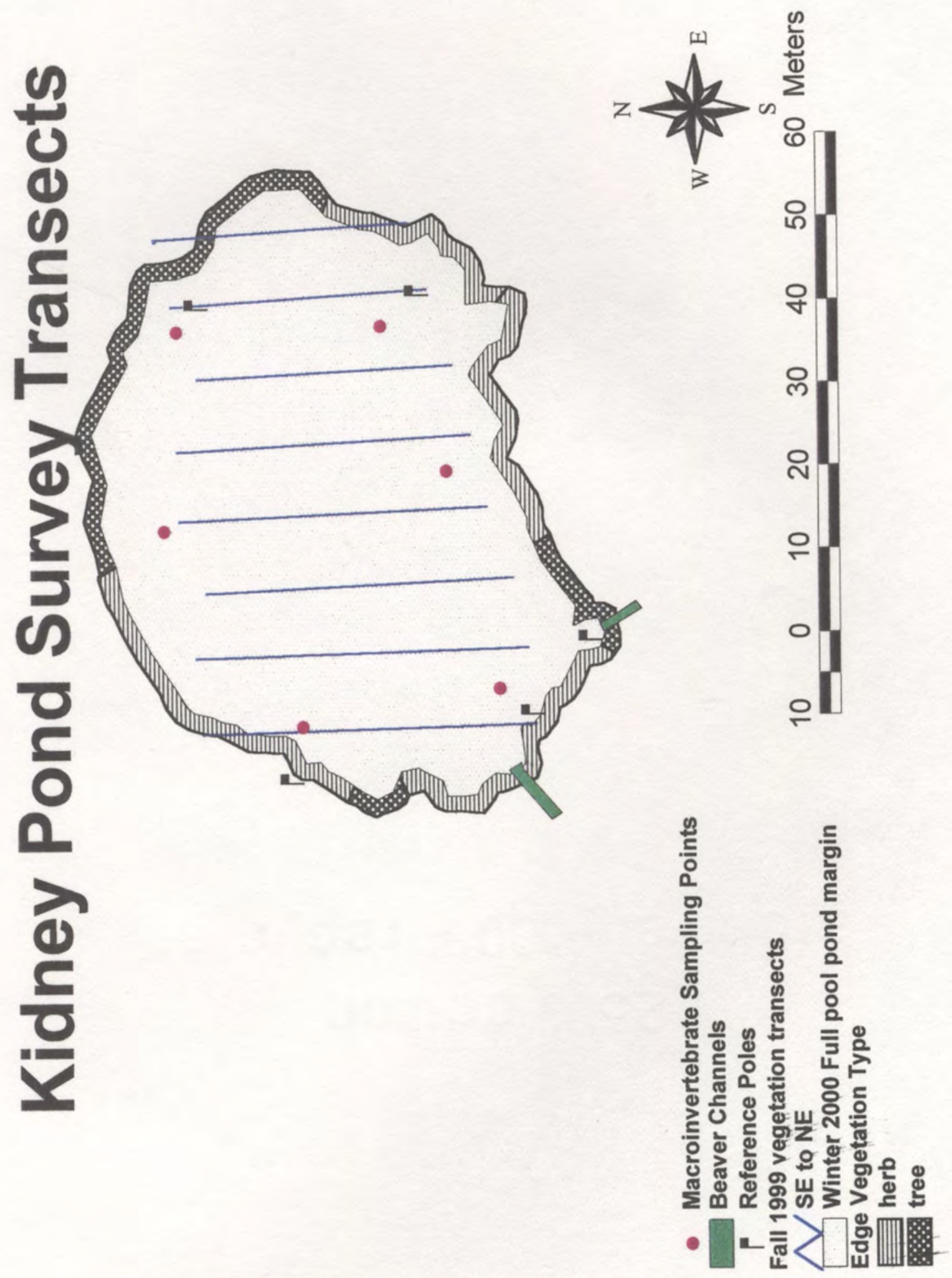




\section{Appendix C - Survey Transects}

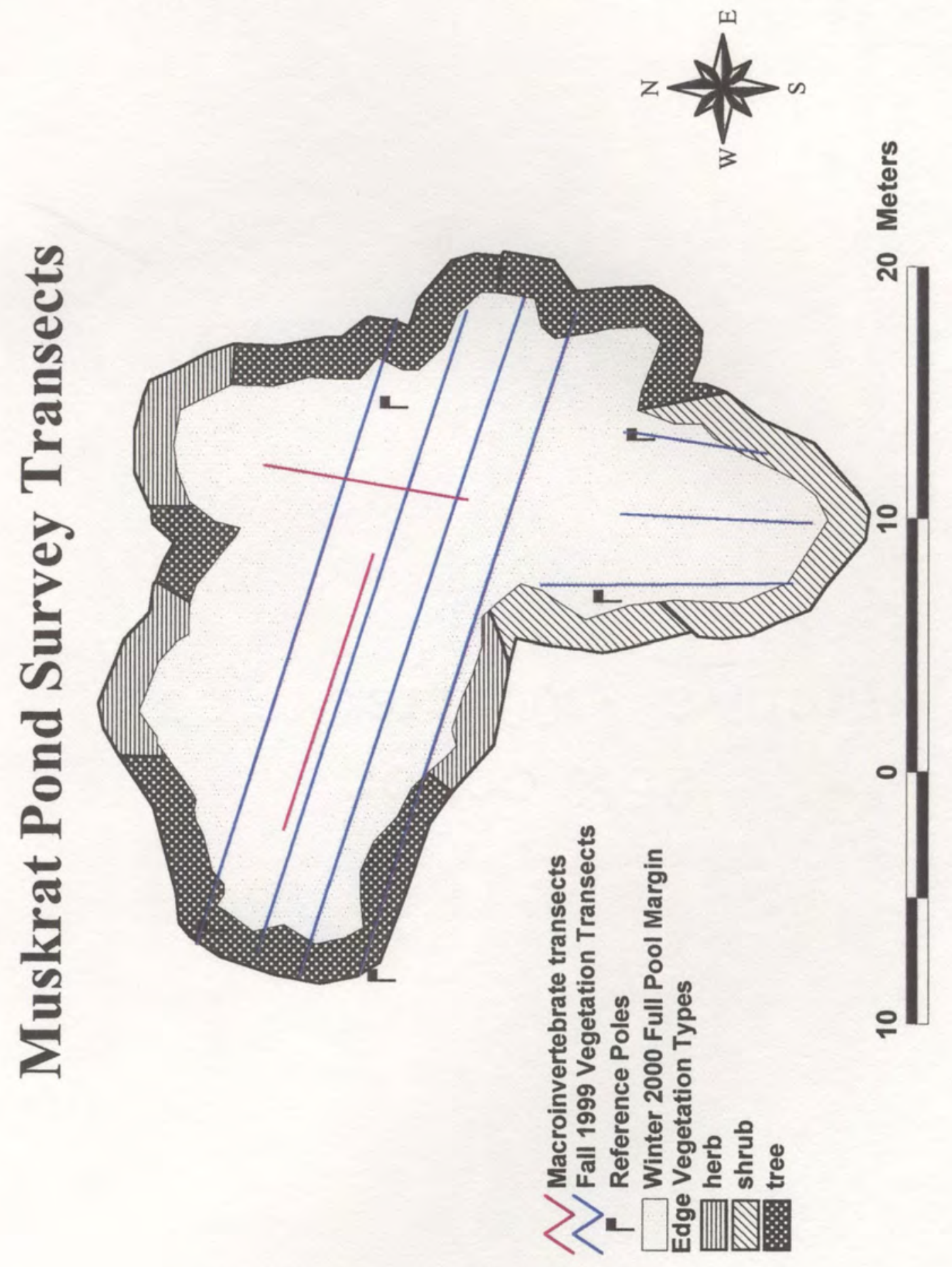




\section{Appendix C: Survey Transects}

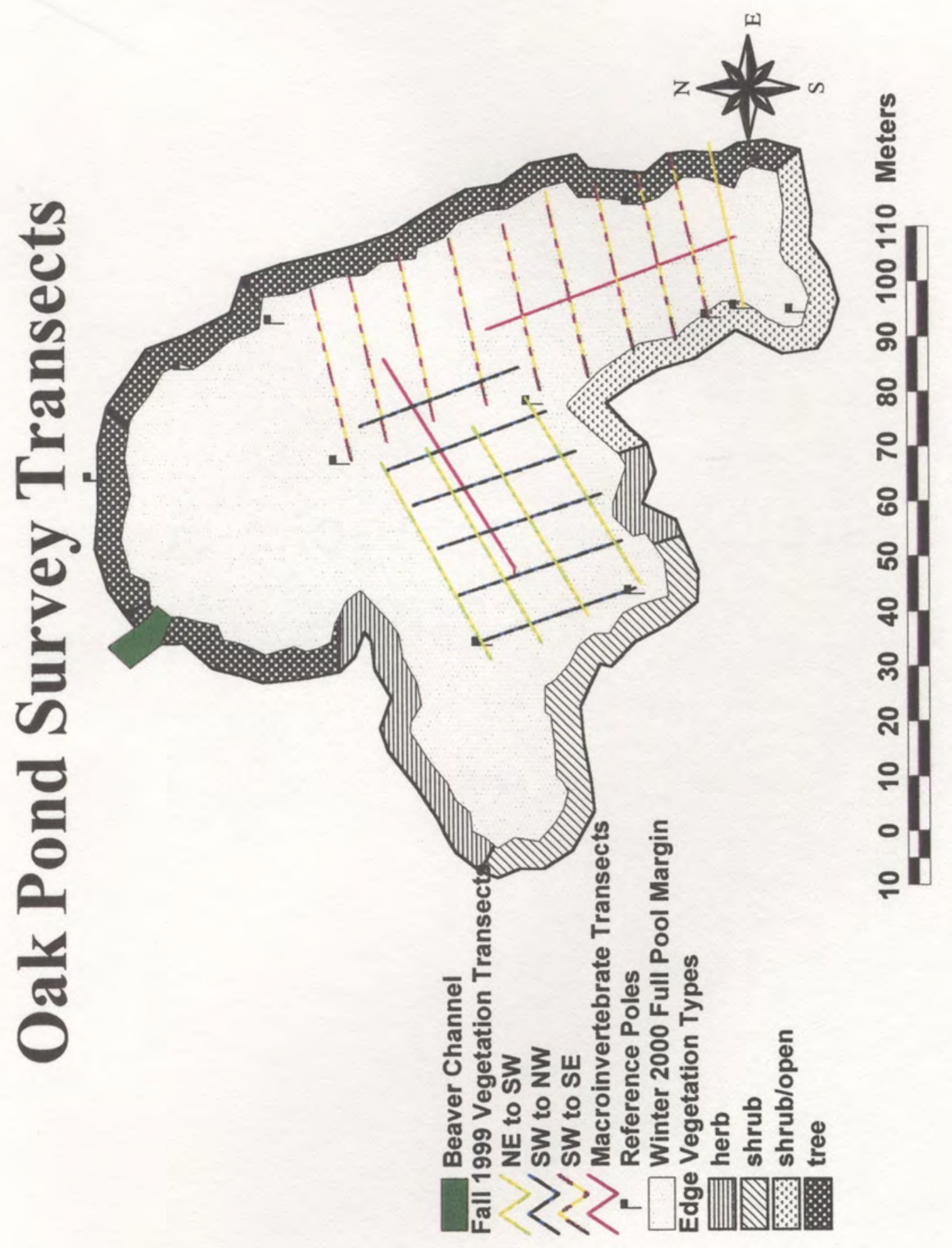


86

\section{Appendix C: Survey Transects}

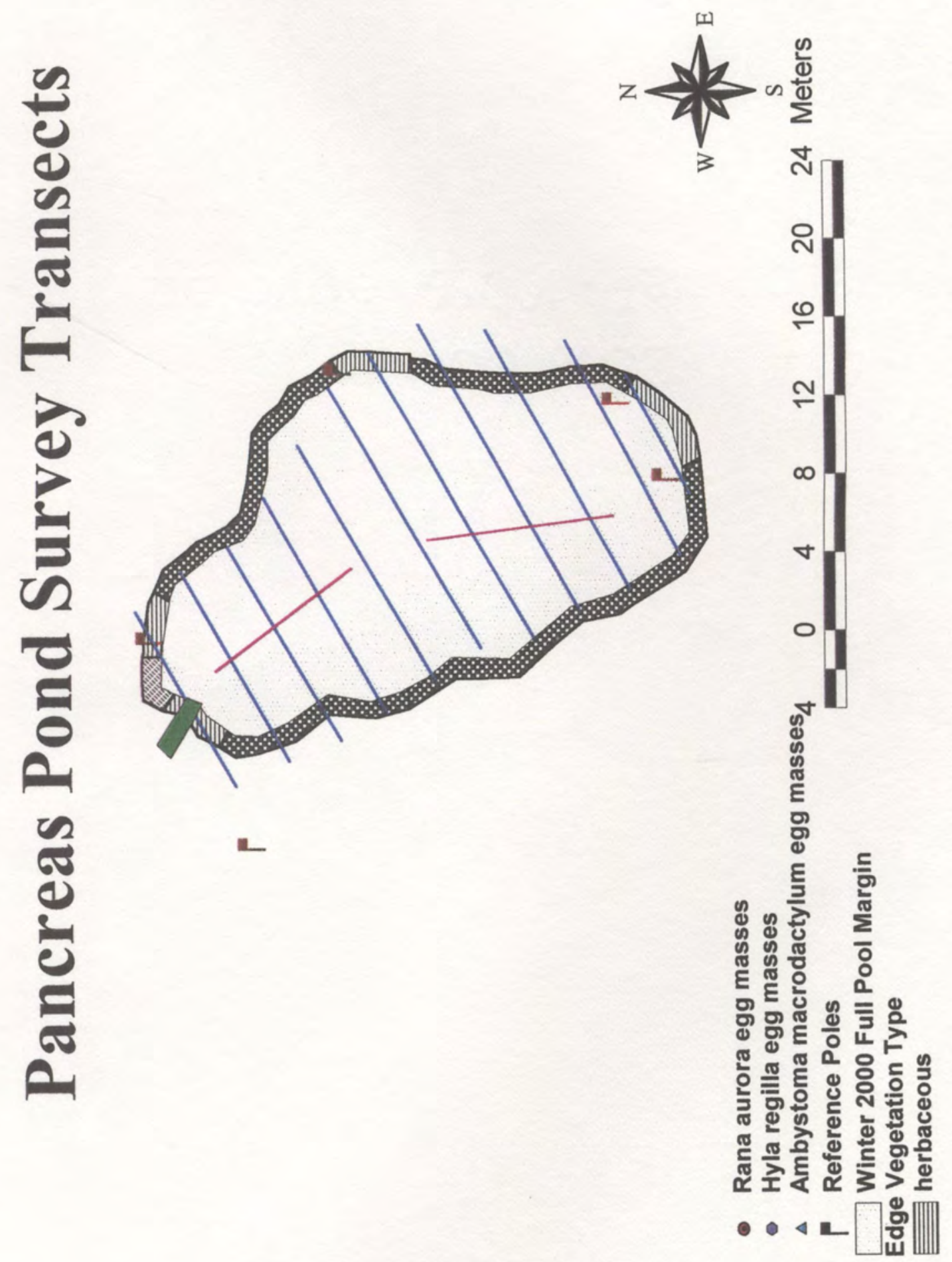


87

\section{Appendix C: Survey Transects}

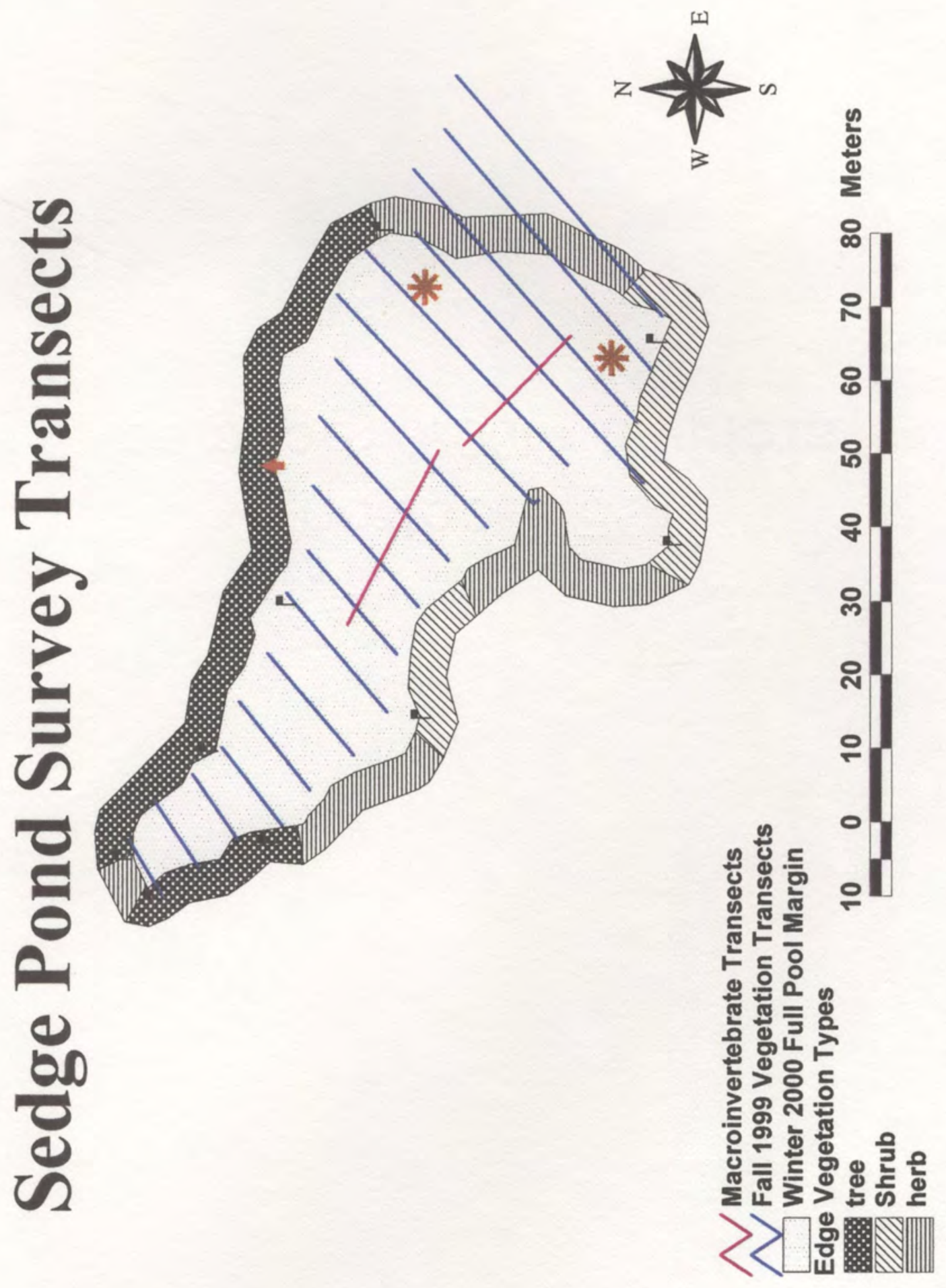


88

\section{Appendix C; Survey Transects}

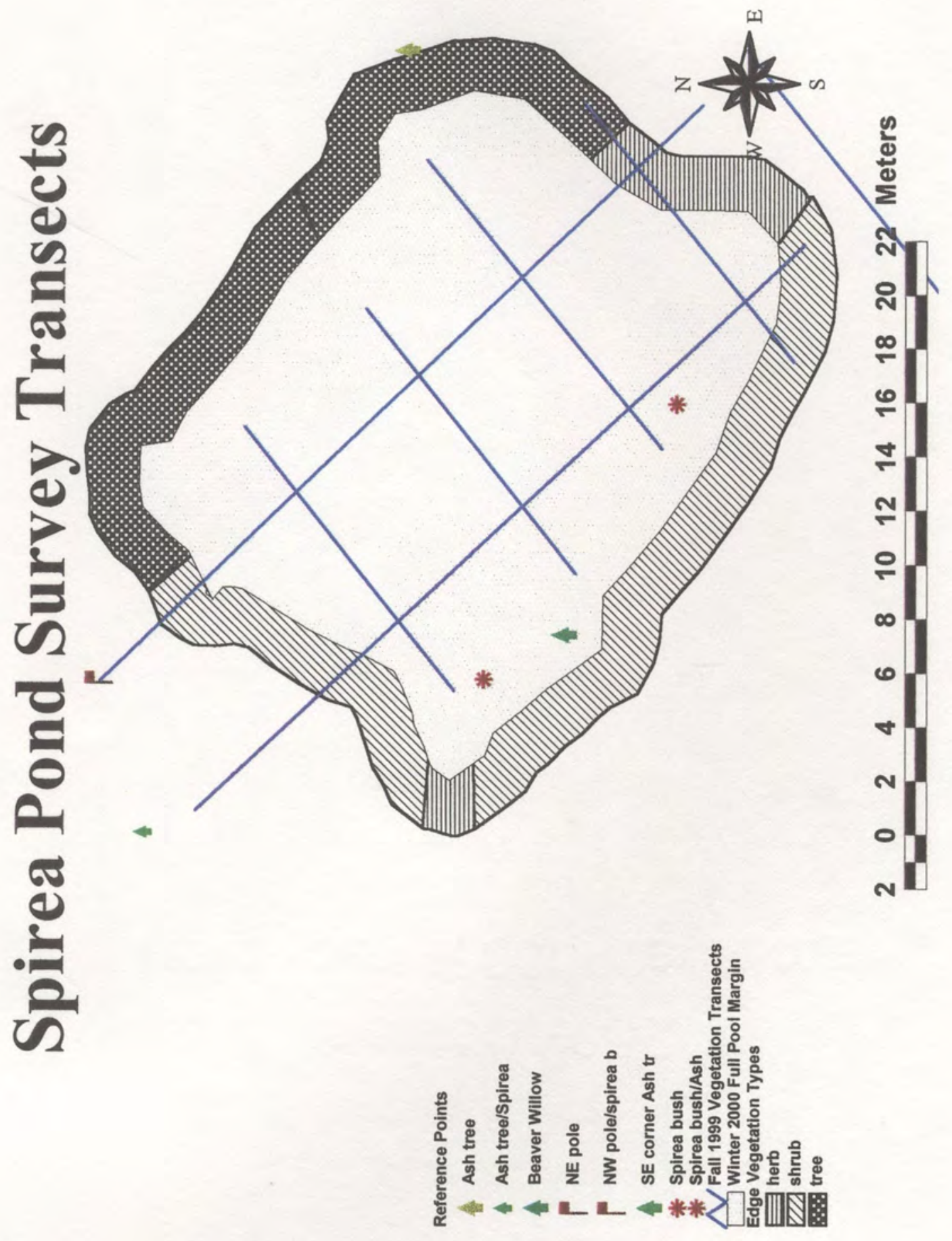




\section{Appendix D: Egg Mass/Water Quality Survey Effort}

\begin{tabular}{|c|c|c|c|c|}
\hline Pond & Dates & $\frac{\text { Effort }}{\text { (hrs) }}$ & $\frac{\text { Number of }}{\text { (\#people) }}$ & $\frac{\text { Effort }}{\text { (person*hours) }}$ \\
\hline Butterfiv & $2-\mathrm{Feb}$ & 2.3 & 6 & 13.5 \\
\hline & 11-Feb & 2.5 & 4 & 10.0 \\
\hline & $21-\mathrm{Feb}$ & 1.0 & 1 & 10 \\
\hline & 13-Mar & 1.3 & 2 & 2.6 \\
\hline & 27-Mar & 1.0 & 3 & 3.0 \\
\hline & 30-Apr & 1.0 & 2 & 2.0 \\
\hline Subtotal & 6 days & 9.1 & & 32.1 \\
\hline Kidney & 2-Feb & 0.5 & 6 & 3.0 \\
\hline & 11-Feb & 3.0 & 4 & 12.0 \\
\hline & 23-Feb & 1.6 & 2 & 3.2 \\
\hline & 10-Mar & 0.8 & 2 & 1.5 \\
\hline & 13-Mar & 0.5 & 1 & 0.5 \\
\hline & 14-Mar & 0.2 & 2 & 0.3 \\
\hline & 24-Mar & 0.8 & 3 & 2.4 \\
\hline & 4-Apr & 1.0 & 2 & 2.0 \\
\hline & 30-Apr & 0.8 & 2 & 1.6 \\
\hline Subtotal & 9 days & 9.1 & & 26.5 \\
\hline Mnskrat & 3-Feb & 0.6 & 5 & 3.0 \\
\hline & 9-Feb & 2.0 & 6 & 120 \\
\hline & 3-Mar & 2.6 & 4 & 10.4 \\
\hline & 6-Mar & 2.8 & 3 & 8.4 \\
\hline & 30-Mar & 0.3 & 1 & 0.3 \\
\hline & 31-Mar & 1.5 & 1 & 1.5 \\
\hline & $1-\mathrm{Apr}$ & 0.2 & 1 & 0.2 \\
\hline & 28-Apr & 1.0 & 1 & 1.0 \\
\hline Subtotal & 8 days & 11.0 & & 36.8 \\
\hline Oak & 19-Jan & 2.0 & 2 & 4.0 \\
\hline & 3-Feb & 2.0 & 3 & 6.0 \\
\hline & 14-Feb & 6.5 & 2 & 16.0 \\
\hline & $16-\mathrm{Feb}$ & 5.0 & 2 & 16.0 \\
\hline & 25-Feb & 1.3 & 2 & 2.6 \\
\hline & 8-Mar & 1.3 & 6 & 7.8 \\
\hline & 10-Mar & 3.0 & 3 & 9.0 \\
\hline & 16-Mar & 0.5 & 1 & 0.5 \\
\hline & 17-Mar & 0.3 & 1 & 0.3 \\
\hline & 21-Mar & 0.3 & 1 & 0.3 \\
\hline & 22-Mar & 0.3 & 1 & 0.3 \\
\hline & 23-Mar & 0.3 & 2 & 0.5 \\
\hline & 4-Apr & 1.0 & 2 & 2.0 \\
\hline & 27-Ax & 1.3 & 3 & 3.9 \\
\hline & 28-Apr & 0.3 & 1 & 0.3 \\
\hline Subtotal & 15 days & 23.9 & & 69.4 \\
\hline Pancreas & 2-Feb & 0.5 & 6 & 3.0 \\
\hline & 11-Feb & 2.5 & 4 & 10.0 \\
\hline & 23-Feb & 1.5 & 5 & 7.3 \\
\hline & 1-Mar & 1.0 & 2 & 2.0 \\
\hline & 10-Mar & 0.5 & 2 & 10 \\
\hline & 14-Mar & 0.8 & 2 & 1.6 \\
\hline & 4-Apr & 13 & 2 & 2.5 \\
\hline & 30-Apr & 2.0 & 2 & 4.0 \\
\hline Subtotal & 8 days & 10.0 & & 31.4 \\
\hline Sedge & 27-Jan & 1.6 & 4 & 6.4 \\
\hline & 4-Feb & 2.5 & 5 & 12.5 \\
\hline & 16-Feb & 1.8 & 6 & 10.8 \\
\hline & 18-Feb & 1.5 & 2 & 3.0 \\
\hline & 16-Mar & 0.6 & 1 & 0.6 \\
\hline & 17-Mar & 1.5 & 3 & 4.5 \\
\hline & 21-Mar & 0.3 & 1 & 0.3 \\
\hline & 22-Mar & 0.2 & 1 & 0.2 \\
\hline & 23-Mar & 0.3 & 2 & 0.6 \\
\hline & 4-Apr & 0.8 & 2 & 16 \\
\hline & 27-Apr & 0.8 & 3 & 2.4 \\
\hline & 28-Apr & 0.3 & 1 & 0.3 \\
\hline Subtotal & 12 days & 12.1 & & 43.1 \\
\hline Spirea & 2-Feb & 0.4 & 6 & 2.4 \\
\hline & 11-Feb & 1.5 & 3 & 4.5 \\
\hline & 23-Feb & 0.2 & 1 & 0.2 \\
\hline & 1-Mar & 0.1 & 1 & 0.1 \\
\hline & 14-Mar & 0.3 & 3 & 0.9 \\
\hline & 27-Mar & 0.2 & 3 & 0.5 \\
\hline & 29-Mar & 0.1 & 1 & 0.1 \\
\hline & 30 -Apr & 0.8 & 2 & 16 \\
\hline Subtotal & 8 days & 3.5 & & 10.2 \\
\hline TOTALS & 33 davs & 787 & & 249.4 \\
\hline
\end{tabular}




\section{Appendix E: Mapping Vegetation and Pond Margins Effort}

\begin{tabular}{|l|c|c|c|c|}
\hline \multicolumn{1}{|c|}{ Pond } & Dates & $\frac{\text { Effort }}{\text { (hr) }}$ & $\frac{\text { Number of }}{\text { \#People }}$ & $\begin{array}{c}\text { Effort } \\
\text { (person * hours) }\end{array}$ \\
\hline \hline Muskrat & $3 / 06 / 00$ & 1.5 & 2 & 3.0 \\
\hline Sedge & $3 / 17 / 00$ & 2.0 & 3 & 6.0 \\
\hline Oak & $3 / 10 / 00$ & 3.0 & 3 & 9.0 \\
\hline Pancreas & $3 / 24 / 00$ & 1.0 & 3 & 3.0 \\
\hline Kidney & $3 / 24 / 00$ & 1.0 & 3 & 3.0 \\
\hline Spirea & $3 / 30 / 00$ & 0.5 & 2 & 1.0 \\
\hline Butterfly & $3 / 30 / 00$ & 0.5 & 2 & 1.0 \\
\hline Totals & $\underline{\mathbf{5 d a v s}}$ & $\mathbf{9 . 5}$ & - & $\mathbf{2 6 . 0}$ \\
\hline
\end{tabular}




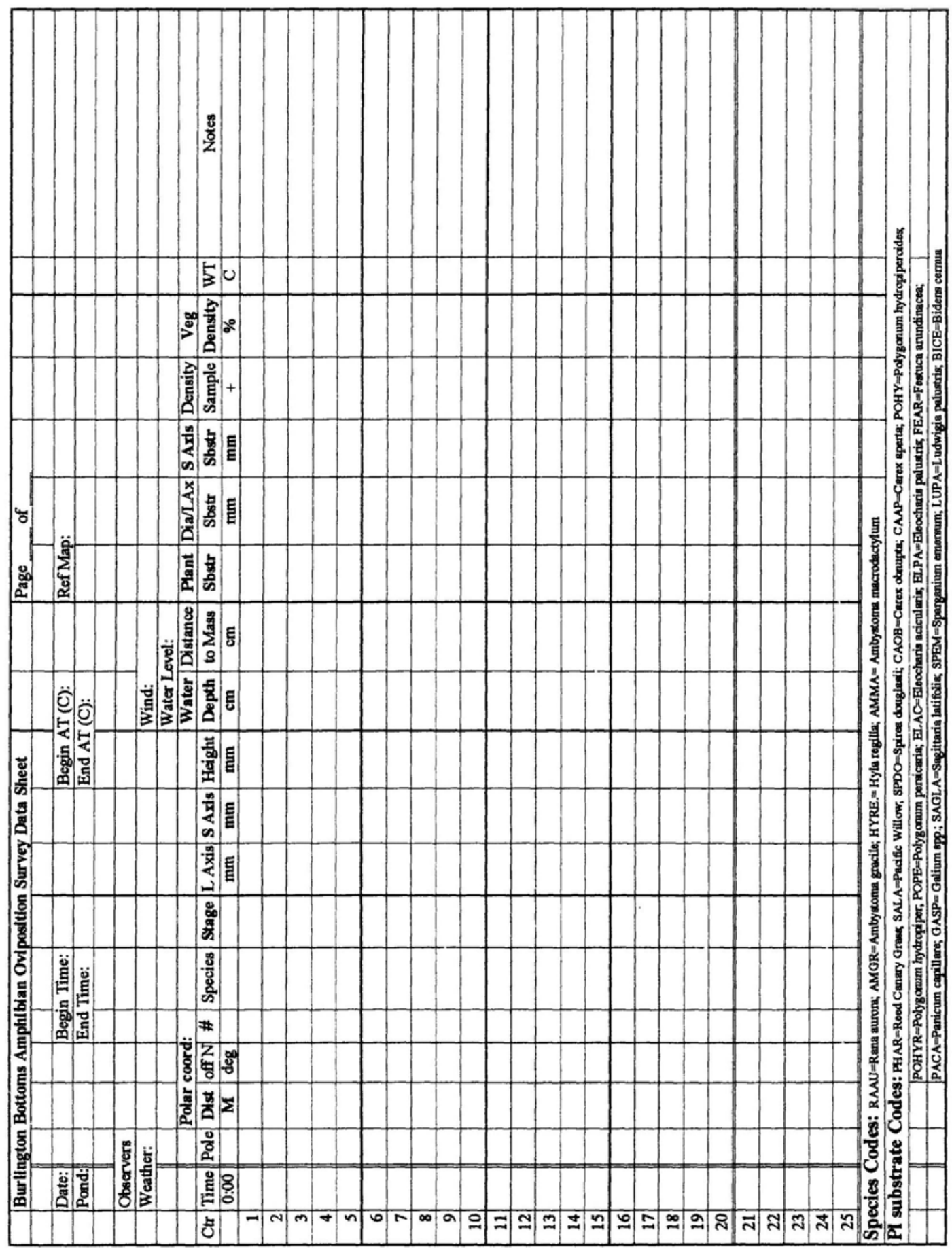




\section{Appendix G: Protocol for Egg Mass Surveys}

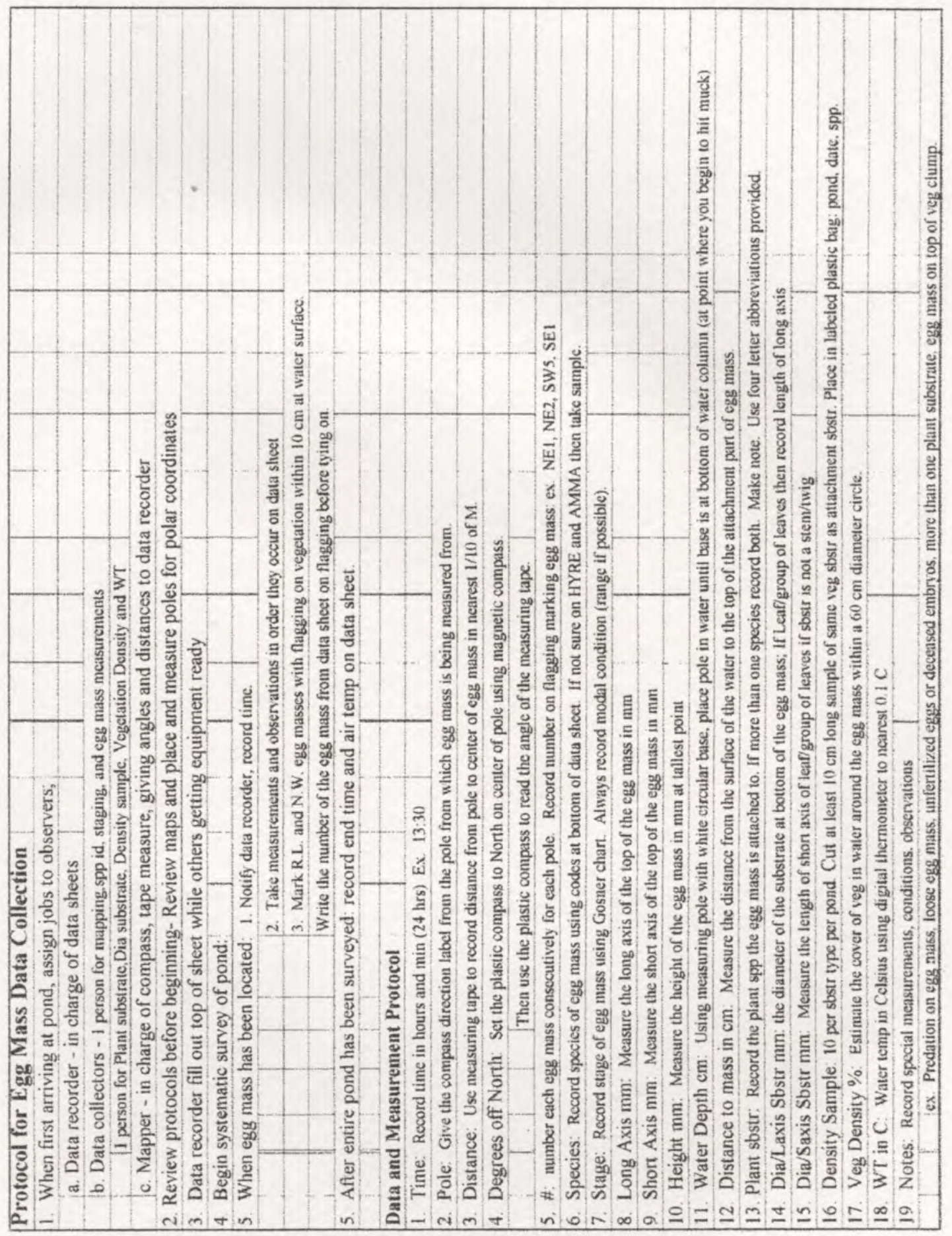


Callison: Factors Influencing Pond-breeding Amphibian Oviposition

Appendix H: Fish Sampling Schedule

\begin{tabular}{|l|c|c|c|c|c|c|c|c|c|c|c|}
\hline \multirow{2}{*}{ Pond } & \multicolumn{9}{|c|}{ Sampling Date in 2000 (number of traps placed on each date indicated) } \\
\cline { 2 - 13 } & $2 / 11$ & $3 / 10$ & $3 / 13$ & $3 / 17$ & $3 / 21$ & $3 / 22$ & $3 / 23$ & $3 / 24$ & $3 / 31$ & $4 / 01$ & $4 / 28$ \\
\hline Kidney & & 3 & 3 & & & & & 3 & & & \\
\hline Muskrat & & & & & & & & & 3 & 3 & \\
\hline Oak & & & & 3 & 3 & & 3 & 3 & & & 3 \\
\hline Pancreas & 3 & 3 & 3 & & & & & & & & \\
\hline Sedge & & & & 3 & & 3 & 3 & & & & 3 \\
\hline Spirea & 3 & & & & & & & & & & \\
\hline
\end{tabular}




\section{Appendix I: Plant Species Addressed in This Study}

\begin{tabular}{|c|c|c|c|c|c|}
\hline Common Name & Scientific Names & Code & Status $^{1}$ & $\begin{array}{l}\text { Structura } \\
1 \text { Group }\end{array}$ & $\underset{3}{\text { Macrohabitat }}$ \\
\hline Beggar's ticks & Bidens cermua & BICE & $\mathrm{N}$ & $\mathrm{H}$ & $\mathrm{T} / \mathrm{E}$ \\
\hline Columbia sedge & Carex aperta & CAAP & $\mathrm{N}$ & $\mathrm{H}$ & $\mathrm{E}$ \\
\hline Slough sedge & Carex obnupta & $\mathrm{CAOB}$ & $\mathrm{N}$ & $\mathrm{H}$ & $\mathrm{E}$ \\
\hline Needle spikerush & Eleocharis acicularis & ELAC & $\mathrm{N}$ & $\mathrm{H}$ & $\mathrm{E} / \mathrm{T}$ \\
\hline Ovate spikerush & Eleocharis ovata & ELOV & $\mathrm{N}$ & $\mathrm{H}$ & $\mathrm{E} / \mathrm{T}$ \\
\hline Creeping spikerush & Eleocharis palustris & ELPA & $\mathrm{N}$ & $\mathrm{H}$ & $\mathrm{E} / \mathrm{T}$ \\
\hline Common horsetail & Equisetum arvense & EQAR & $\mathrm{N}$ & $\mathrm{H}$ & $\mathrm{T}$ \\
\hline Tall fescue & Festuca arundinacea & FEAR & I & $\mathrm{H}$ & $\mathrm{T}$ \\
\hline Bedstraw & Galium spp. & GAsp & $\mathrm{N}$ & $\mathrm{H}$ & $\mathrm{T}$ \\
\hline Pointed rush & Juncus acuminatus & JUAC & $\mathrm{N}$ & $\mathrm{H}$ & $\mathrm{T} / \mathrm{E}$ \\
\hline Water purslane & Ludwigia palustris & LUPA & I & $\mathrm{H}$ & $\mathrm{F} / \mathrm{S}$ \\
\hline Witch grass & Panicum capillaris & PACA & $\mathrm{N}$ & $\mathrm{H}$ & $\mathrm{T} / \mathrm{E}$ \\
\hline Reed canarygrass & Phalaris arundinaceae & PHAR & $\mathrm{I}$ & $\mathrm{H}$ & $\mathrm{E} / \mathrm{T}$ \\
\hline Waterpepper, smartweed & Polygonum spp. & POsp & $\mathrm{N}$ & $\mathrm{H}$ & $\mathrm{E} / \mathrm{T}$ \\
\hline Wapato & Sagittaria latifolia & SGLA & $\mathrm{N}$ & $\mathrm{H}$ & $\mathrm{E}$ \\
\hline Pacific willow & Salix lasiandra & SALA & $\mathrm{N}$ & $\mathrm{T}$ & $\mathrm{E} / \mathrm{T}$ \\
\hline Nightshade & Solanum dulcamara & SODU & I & $\mathrm{H}$ & $\mathrm{T}$ \\
\hline Simple-stem burreed & Sparganium emersum & SPEM & $\mathrm{N}$ & $\mathrm{H}$ & $\mathrm{E}$ \\
\hline $\begin{array}{l}\text { Hardhack or Douglas' } \\
\text { spirea }\end{array}$ & Spirea douglasii & SPDO & $\mathrm{N}$ & Sh & $\mathrm{E} / \mathrm{T}$ \\
\hline
\end{tabular}

${ }^{1} \mathrm{~N}=$ native, $\mathrm{I}=$ introduced, nonnative

${ }^{2} \mathrm{H}=$ Herbaceous, $\mathrm{T}=\mathrm{Tree}, \mathrm{Sh}=$ shrub

${ }^{3} \mathrm{E}=$ Emergent, $\mathrm{F}=$ Floating, $\mathrm{S}=$ Submerged, $\mathrm{T}=$ Terrestrial

Note: Data for this table are based on a combination of (Hitchcock and Cronquist 1973, Guard 1995, Cooke 1997) 


\section{Appendix J-Attachment Brace Variation}

Direct counts of egg masses found on the different vegetation brace types regardless of plant species. Combinations of stems and leaves were abbreviated with " $S$ " for stem and " $L$ " for leaf. The number of letters represents the number of stems or leaves found within the egg mass.

Attachment Brace Variation for RAAU Egg Masses

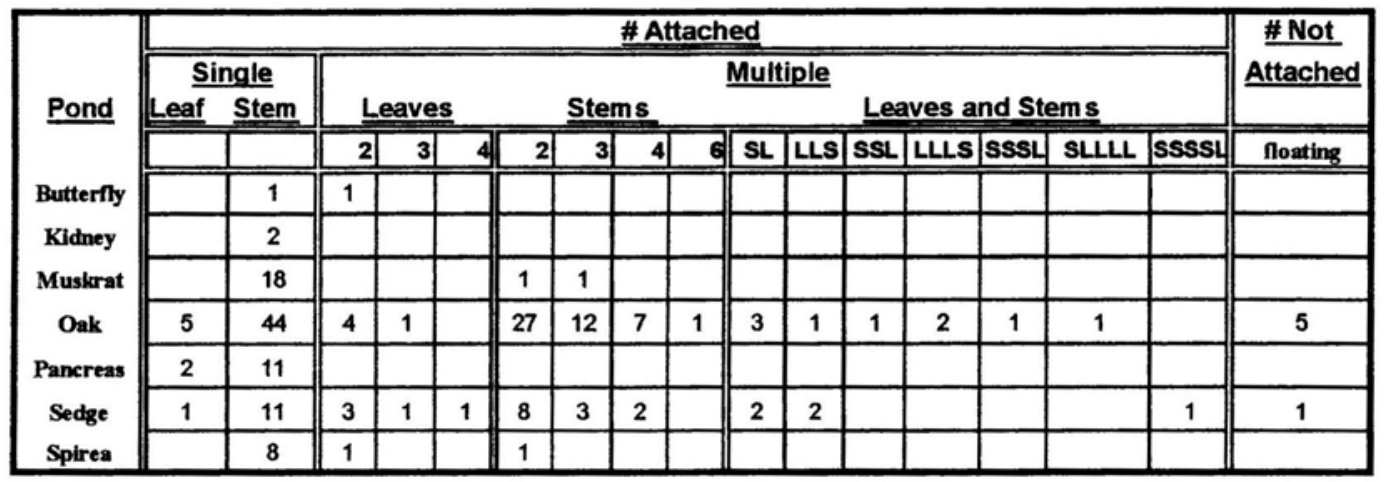

Attachment Brace Variation for AMGR Egg Masses

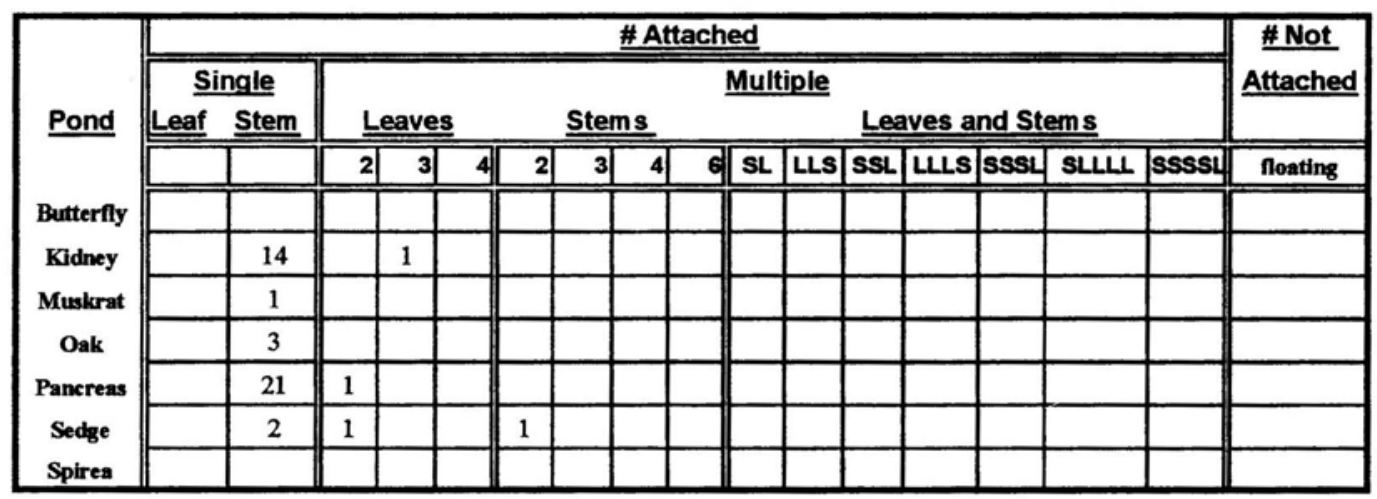

Attachment Brace Variation for AMMA Egg Masses

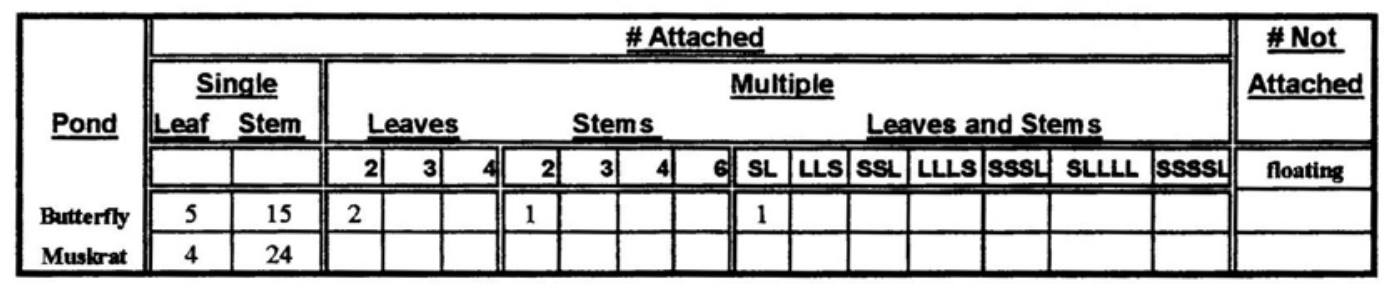

Attachment Brace Variation for HYRE Egg Masses

\begin{tabular}{|c|c|c|c|c|c|c|c|c|c|c|c|c|c|c|c|c|}
\hline \multirow{4}{*}{ Pond } & \multicolumn{15}{|c|}{ Attached } & \multirow{4}{*}{\begin{tabular}{|c|}
$\begin{array}{c}\text { \# Not } \\
\text { Attached }\end{array}$ \\
floating \\
\end{tabular}} \\
\hline & \multirow{2}{*}{\multicolumn{2}{|c|}{$\begin{array}{l}\text { Single } \\
\text { Leaf Stem }\end{array}$}} & \multicolumn{13}{|c|}{ Multiple } & \\
\hline & & & \multicolumn{3}{|c|}{ Leaves } & \multicolumn{3}{|c|}{ Stems } & \multicolumn{7}{|c|}{ Leaves and Stems } & \\
\hline & & & $\underline{2}$ & 3 & 4 & 2 & 3 & 4 & $5 \mathrm{SL}$ & LLS & SSL & LLLS & sssL & SLLLL & ssssi & \\
\hline Butterfly & 7 & 12 & 2 & 1 & 1 & 1 & 1 & & & & & & & & & \\
\hline Muskrat & 5 & 15 & & 3 & & & & & 1 & & & & & & & \\
\hline
\end{tabular}




\section{Appendix K: Pond Oviposition Sites}

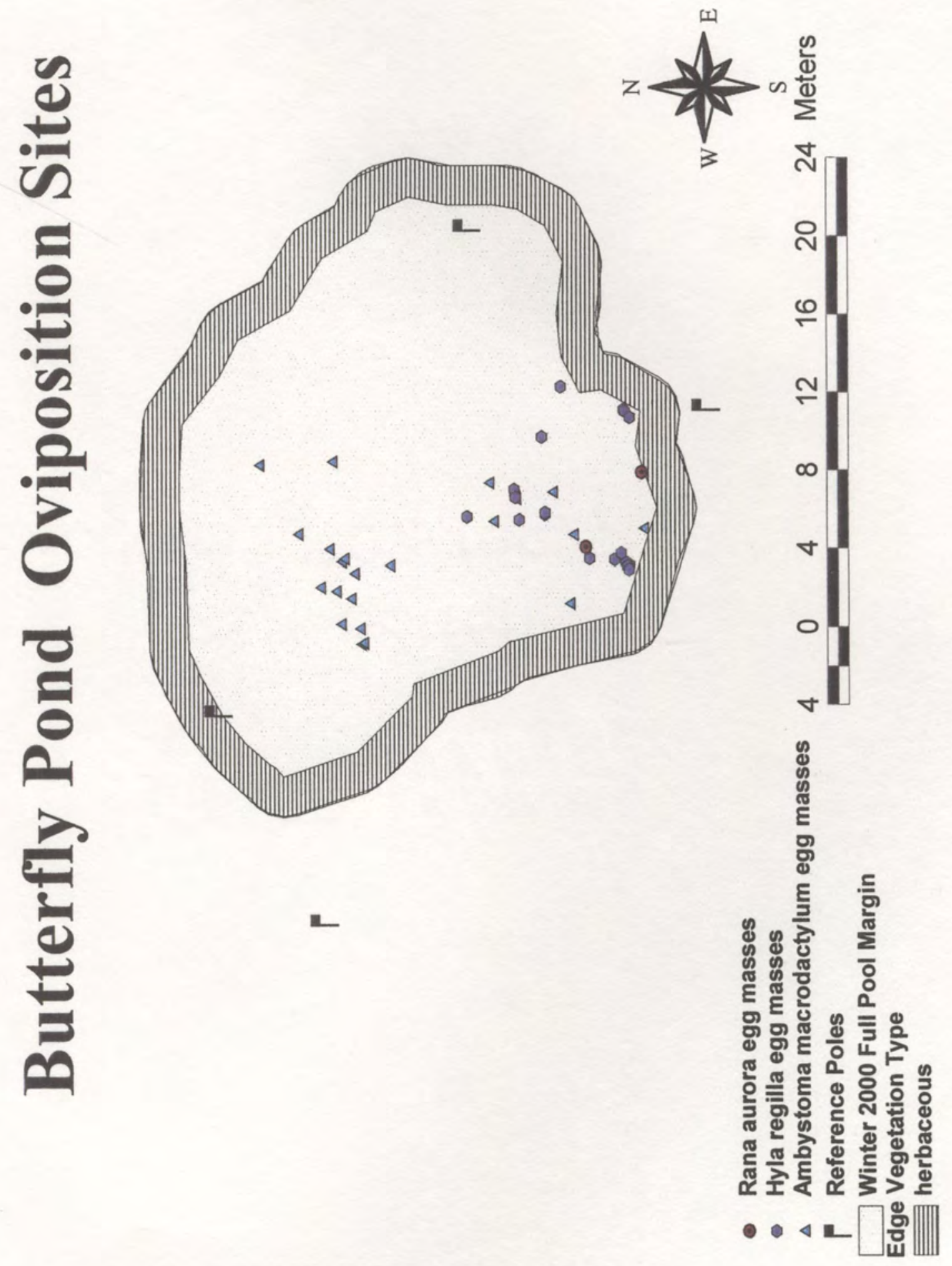




\section{Appendix K - Pond Oviposition Sites}

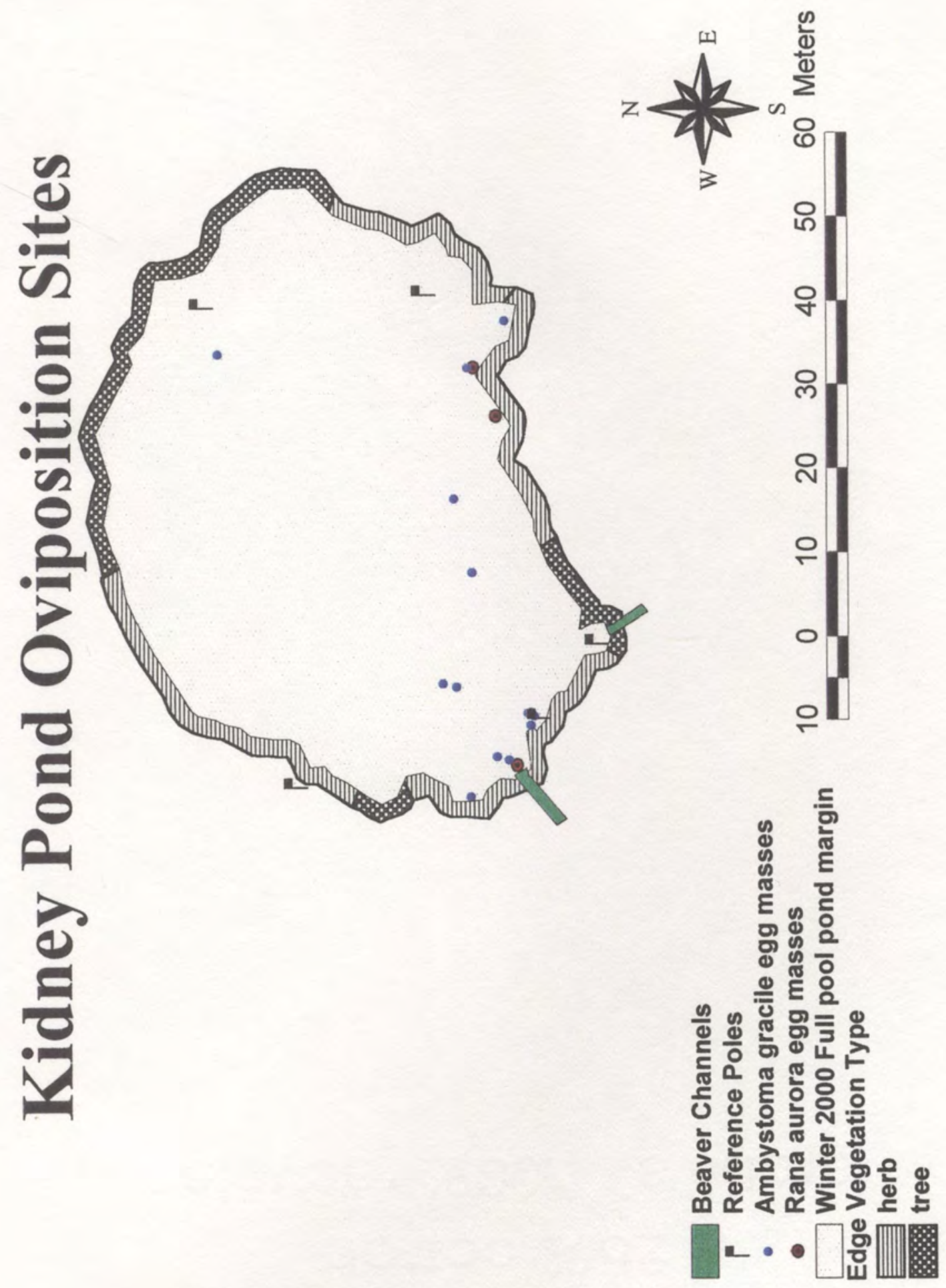


98

\section{Appendix K - Pond Oviposition Sites}

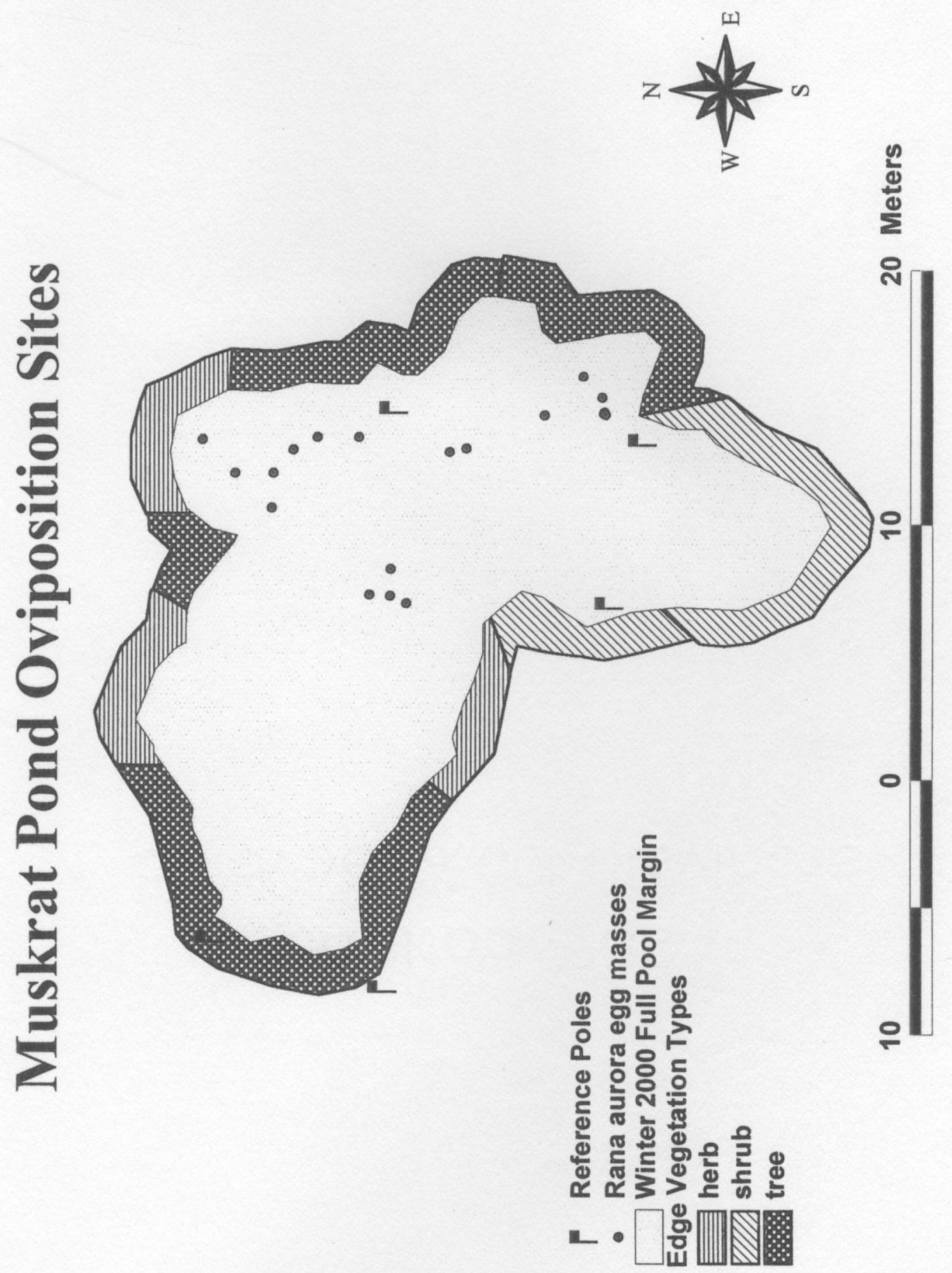


99

\section{Appendix K: Pond Oviposition Sites}

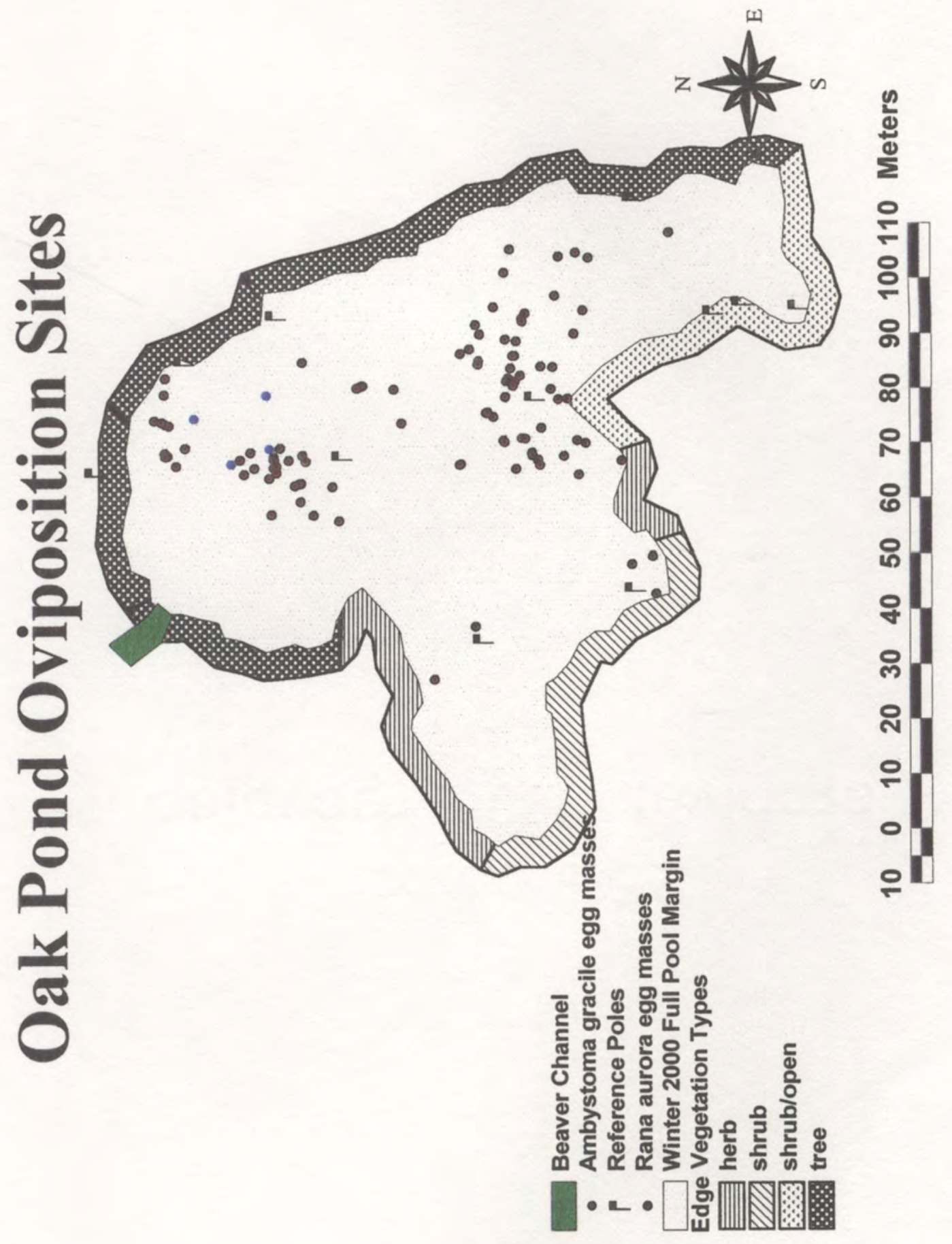




\section{Appendix K: Pond Oviposition Sites}

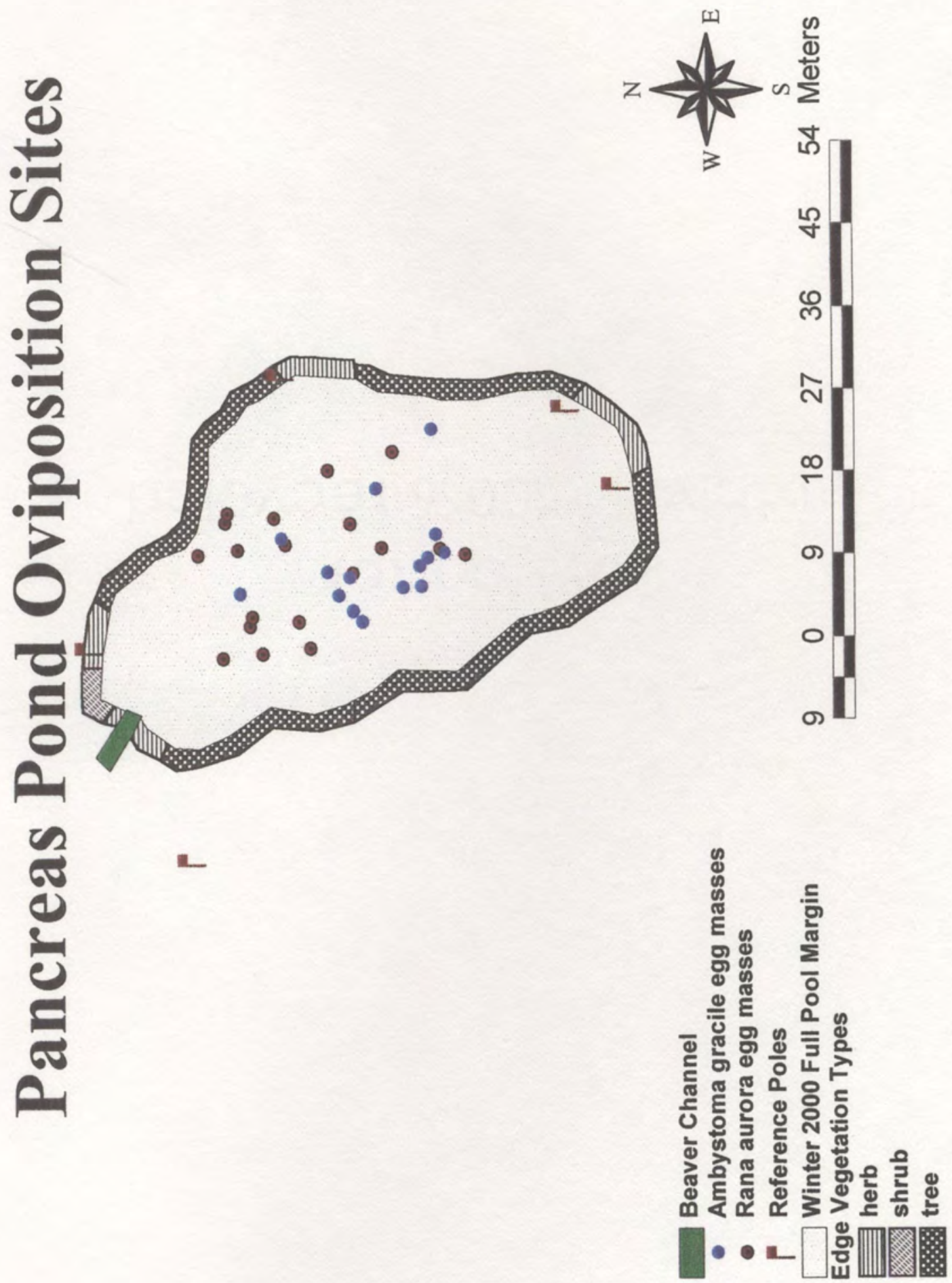




\section{1 \\ Appendix K - Pond Oviposition Sites}

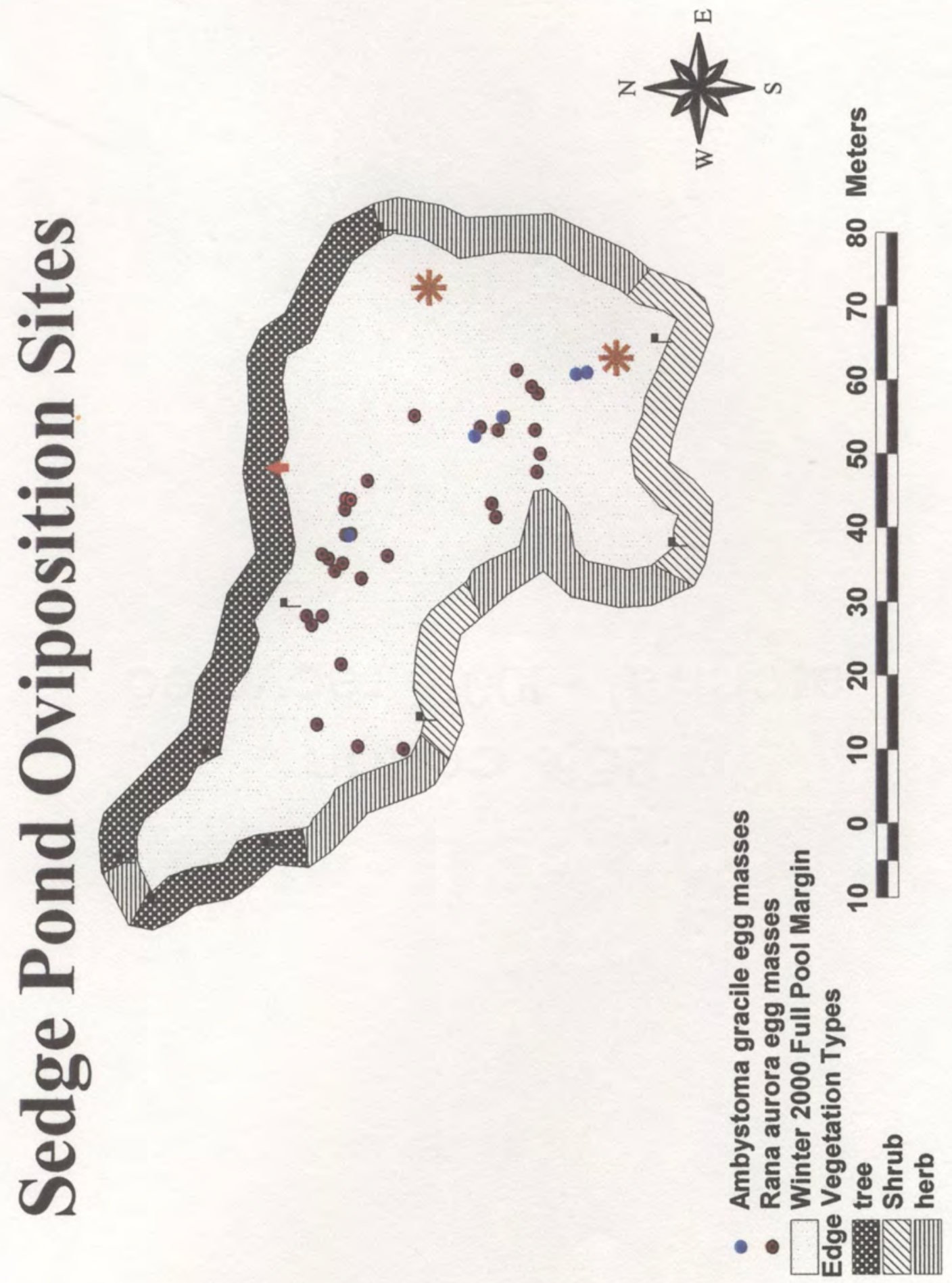




\section{Appendix K - Pond Oviposition Sites}

102

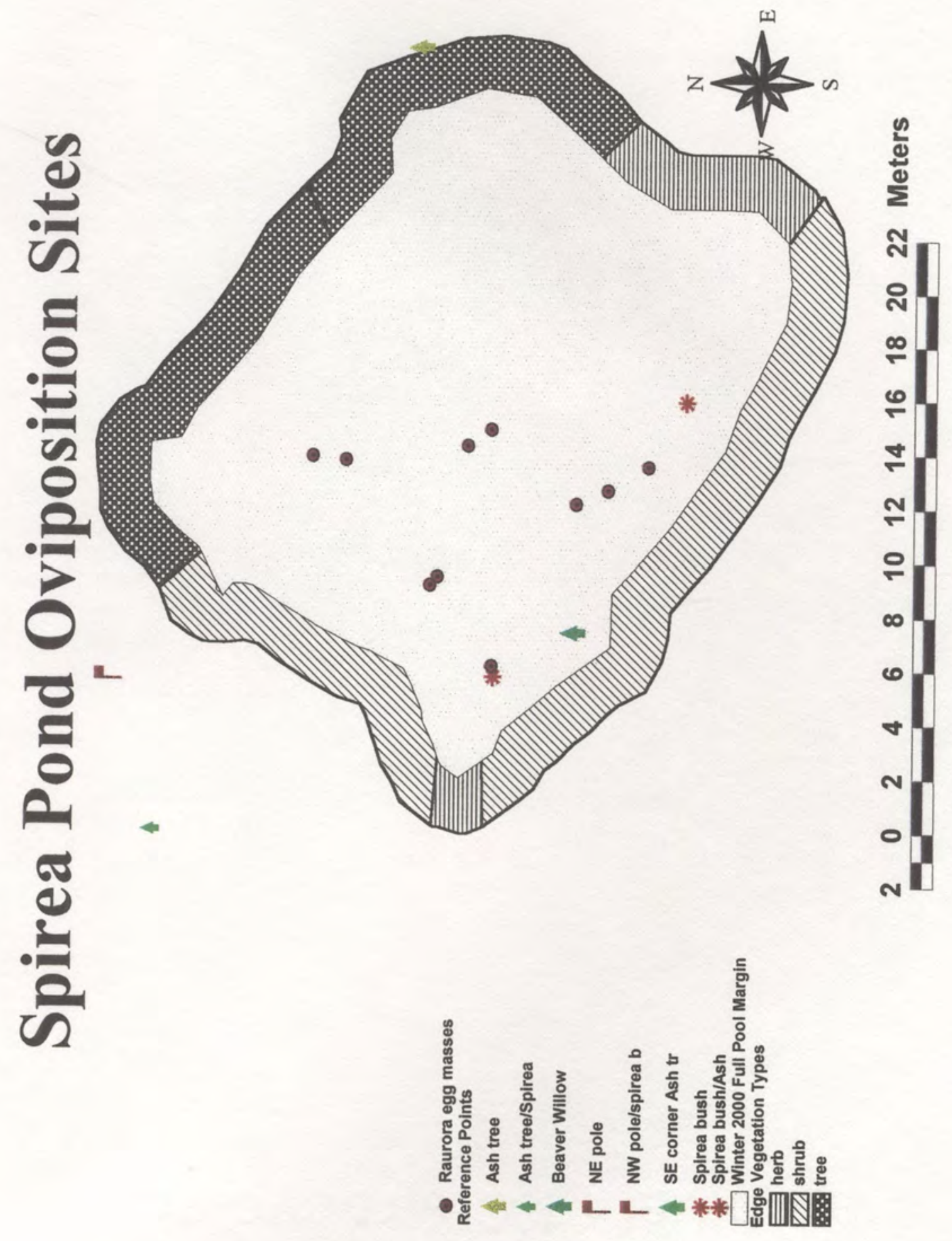




\section{Appendix L: Macroinvertebrate Sampling Results}

These surveys were done the week of 27 March to the 4 April 2000. The ponds are listed alphabetically. Macroinvertebrates collected from the sweep net surveys were identified to the family level. The number of different morphospecies was totaled for each pond. Muskrat had the greatest number of species (12) while Sedge pond had the fewest (5). The other ponds had between 8 and 10 species. Grouping the macroinvertebrates by feeding type (herbaceous versus predator species) showed that all of the ponds had greater than $69 \%$ macroinvertebrate herbivores present. Fairy shrimp (Order Crustacea: Eubranchipodia) and snails (Gastropoda) were the most frequent macroinvertebrates encountered in all the ponds. The presence of copepods and cladocera were noted but a relative count was not obtained. A comparison of the numbers of macroinvertebrates to the number of northwestern salamander egg masses revealed only significant correlations for water column species like fairy shrimp and mayflies.

\begin{tabular}{|c|c|c|c|c|c|c|c|c|}
\hline \multicolumn{9}{|c|}{ Sweep Net Survey Results } \\
\hline Pond & Predators & Herbivores & \# Morphospecies & $\begin{array}{c}\text { Dominant Species } \\
(>\mathbf{1 0} \%)\end{array}$ & Count & Percent & $\begin{array}{l}\text { Total } \\
\text { Count }\end{array}$ & Other MorphoSpecies Groups \\
\hline Butterfly & $2 \%$ & $98 \%$ & 8 & $\begin{array}{l}\text { Eubranchiopoda } \\
\text { (fairy shrimp) }\end{array}$ & 570 & $85 \%$ & 671 & $\begin{array}{l}\text { Gastropoda, Ephemeroptera, Isopoda, } \\
\text { Limnephillidae, Arachnida, Elmidae, } \\
\text { Hirudinidae }\end{array}$ \\
\hline \multirow{4}{*}{ Kidney } & \multirow{4}{*}{$32 \%$} & \multirow{4}{*}{$69 \%$} & \multirow{4}{*}{9} & $\begin{array}{l}\text { Eubranchiopoda } \\
\text { (fiiry shrimp) }\end{array}$ & 9 & $32 \%$ & \multirow{4}{*}{28} & \multirow{4}{*}{$\begin{array}{l}\text { Corixidae, Tipulidae, Hemiptera. } \\
\text { Chaoboridae, Dytiseidae }\end{array}$} \\
\hline & & & & Gastropoda (snail) & $\overline{7}$ & $25 \%$ & & \\
\hline & & & & Elmidae (beetle) & $\overline{4}$ & $14 \%$ & & \\
\hline & & & & Simulidae (Diptera) & 3 & $11 \%$ & & \\
\hline \multirow{3}{*}{ Mnskrat } & \multirow{3}{*}{$11 \%$} & \multirow{3}{*}{$89 \%$} & \multirow{3}{*}{12} & $\begin{array}{l}\text { Eubranchiopoda } \\
\text { (fairy shrimp) }\end{array}$ & 181 & $44 \%$ & \multirow{3}{*}{416} & \multirow{3}{*}{$\begin{array}{l}\text { Limnephillidae, Chaoboridae, } \\
\text { Chironomidae, Dysticidae, Elmidae, } \\
\text { Ephemeroptera, Hydra, Sialidae, } \\
\text { Simnlidae }\end{array}$} \\
\hline & & & & Gastropoda (snail) & 107 & $26 \%$ & & \\
\hline & & & & sow bugs) & 63 & $15 \%$ & & \\
\hline \multirow[t]{2}{*}{ Oak } & \multirow[t]{2}{*}{$9 \%$} & \multirow[t]{2}{*}{$91 \%$} & \multirow[t]{2}{*}{8} & $\begin{array}{l}\text { Eubranchiopoda } \\
\text { (fairy shrimp) }\end{array}$ & 101 & $68 \%$ & \multirow[t]{2}{*}{149} & \multirow[t]{2}{*}{$\begin{array}{l}\text { Isopoda, Limnephillidae, Simnlidae, } \\
\text { Chaoboridae, Elmidae, Firunidae }\end{array}$} \\
\hline & & & & Gastropoda (snail) & 28 & $19 \%$ & & \\
\hline \multirow[b]{2}{*}{ Pancreas } & \multirow[b]{2}{*}{$19 \%$} & \multirow[b]{2}{*}{$81 \%$} & \multirow[b]{2}{*}{10} & Gastropoda (snail) & 32 & $38 \%$ & \multirow[b]{2}{*}{84} & \multirow{2}{*}{$\begin{array}{l}\text { Haliplidae, Limnephillidae, Tipulidae, } \\
\text { Chaoboridae, Dytiscidae, Elmidae, } \\
\text { Hemiptera, Bactidae }\end{array}$} \\
\hline & & & & $\begin{array}{l}\text { Eubranchiopoda } \\
\text { (fairy shrimp) }\end{array}$ & 27 & $32 \%$ & & \\
\hline \multirow{3}{*}{ Sedge } & \multirow{3}{*}{$2 \%$} & \multirow{3}{*}{$98 \%$} & \multirow{3}{*}{5} & $\begin{array}{l}\text { Eubranchiopoda } \\
\text { (fairy shrimp) }\end{array}$ & 80 & $46 \%$ & \multirow{3}{*}{175} & \multirow{3}{*}{ Dytiscidae, Limnephillidae } \\
\hline & & & & Gastropoda (snail) & 45 & $26 \%$ & & \\
\hline & & & & sow bugs) & 39 & $23 \%$ & & \\
\hline
\end{tabular}




\section{Appendix M: Minnow Trap Results}

All the traps were place for 24 hour cycles on the dates listed. Three traps were placed in randomly spaced locations throughout the pond each day. All ponds where fish were caught are connected to a permanent slough. Minnow traps captured only two peamouth (Mylocheilus caurinus), one each in Kidney and Pancreas ponds respectively, and several bullfrog (Rana catesbeiana) tadpoles in Oak and Sedge ponds (Table 20). A dead three-spine stickleback (Gasterosteus aculeatus) was observed and collected during sweep netting in Kidney pond. I observed another dead three-spine stickleback along the shore of Kidney Pond during egg mass sampling. I also observed one mosquito fish (Gambusia affinus) in Pancreas pond while surveying for egg masses. These results agree with the fact that the ponds where nothing was trapped were isolated and temporary in comparison to Oak, Kidney, and Pancreas, which had beaver channels connecting them to a small, permanent slough.

\begin{tabular}{|c|c|c|c|c|c|c|c|c|c|c|}
\hline \multicolumn{11}{|c|}{ Minnow Trap Results } \\
\hline & & & & \multicolumn{6}{|c|}{ Water Depth of Traps and Contents } & \\
\hline & & \multicolumn{2}{|c|}{ Time } & $\mathbf{c m}$ & Species & $\mathbf{c m}$ & Species & $\mathbf{c m}$ & Species & \\
\hline Date & Pond & In & Out & \#1 & Present & $\# 2$ & Present & $\# 3$ & Present & Notes \\
\hline 10-Mar & Kidney & 915 & 1530 & 42 & 0 & 45 & 0 & 35 & 0 & $\begin{array}{l}5 \text { prs of Mallards on pond } \\
\text { when I arrived }\end{array}$ \\
\hline 13-Mar & Kidney & 915 & 1530 & 42 & 0 & 45 & 0 & 35 & 0 & $\begin{array}{l}5 \text { prs of Mallards on pond } \\
\text { when I arrived }\end{array}$ \\
\hline 24-Mar & Kidney & 1332 & 1400 & 30 & $\begin{array}{l}1 \text { Minnow } \\
\text { (peamouth) }\end{array}$ & 30 & 0 & 35 & 0 & \\
\hline 11-Feb & Muskrat & 1300 & 1300 & & & & $\begin{array}{l}\text { AMGR juvenile, } \\
\text { AMMA adult }\end{array}$ & NA & & \\
\hline 31-Mar & Muskrat & 1300 & 1330 & 37 & 0 & 20 & 0 & 30 & 2 HYRE Tadpoles & $\begin{array}{l}\text { Tadpoles immediately swam } \\
\text { out when trap lifted } \\
\end{array}$ \\
\hline 1-Apr & Muskrat & 1330 & 1330 & 37 & 3 Dytiscidae & 20 & 0 & 30 & 0 & \\
\hline 3-Feb & Oak & 1330 & 1320 & 36 & 0 & 19 & 0 & 28 & 0 & \\
\hline 17-Mar & Oak & 1100 & 1100 & 55 & 0 & 65 & 0 & 57 & 0 & \\
\hline 21-Mar & Oak & 1414 & 1148 & 55 & 0 & 65 & 0 & 57 & 1 RACA Tadpole - & $\begin{array}{l}\text { no measurements taken on } \\
\text { tadpole }\end{array}$ \\
\hline 23-Mar & Oak & 1415 & 1415 & 47 & 0 & 50 & $\begin{array}{c}\text { 1adult beetle } \\
\text { (Dytiscid family) }\end{array}$ & 44 & 2 RACA tadpoles & $\begin{array}{l}\# 1 \mathrm{HT} 7.5 \mathrm{cmTL} 5.0 \mathrm{~cm} ; \\
\# 2 \mathrm{HT} 8.0 \mathrm{~cm}, \mathrm{TL} 5.2 \mathrm{~cm}\end{array}$ \\
\hline 28-Apr & Oak & 1040 & 1408 & 55 & $\begin{array}{l}\text { 2 RACA } \\
\text { tadpoles }\end{array}$ & 58 & 1 snail & NA & 0 & Two baited traps tried \\
\hline 11-Feb & Pancreas & 1415 & 1420 & 47 & 0 & 50 & 1 RACA tadpole & 44 & 1 RACA Tadpole - & $\begin{array}{l}\# 2 \text { HT } 8.0 \mathrm{cmTL} 5.0 \mathrm{~cm} \# 3 \mathrm{HT} 9.0 \\
\mathrm{cmTL} 5.5 \mathrm{~cm}\end{array}$ \\
\hline 10-Mar & Pancreas & 949 & 1600 & 40 & 0 & 50 & 0 & 40 & 0 & Some caddis fly larva in traps \\
\hline 14-Mar & Pancreas & 1351 & 1409 & 28 & $\begin{array}{c}1 \text { Minnow } \\
\text { (peamouth) }\end{array}$ & 50 & 0 & 22 & 0 & $\begin{array}{l}\text { Length of fish - } 56 \mathrm{~mm} \text {, } \\
\text { Width - } 14 \mathrm{~mm}\end{array}$ \\
\hline 17-Mar & Sedge & 1012 & 1207 & 46 & 0 & 32 & $\begin{array}{l}1 \text { snail, } 3 \text { Caddis ffy } \\
\text { larva (Trichopteras) }\end{array}$ & 40 & $\begin{array}{c}1 \text { adult beetle } \\
\text { (Dytiscid family) }\end{array}$ & \\
\hline 22-Mar & Sedge & 1012 & 1335 & 37 & 0 & 49 & 0 & 55 & 0 & \\
\hline 23-Mar & Sedge & 1335 & 1448 & 37 & 0 & 49 & 0 & 55 & 0 & \\
\hline 28-Apr & Sedge & 1150 & 1350 & 68 & $\begin{array}{l}\text { 10 RACA } \\
\text { tadpoles }\end{array}$ & 50 & 2 RACA tadpoles & NA & 0 & Two baited traps tried \\
\hline 11-Feb & Spirea & 1448 & 1350 & 37 & 0 & 49 & 0 & 55 & 0 & $\begin{array}{l}\text { Water levels dropped too low } \\
\text { to do anymore }\end{array}$ \\
\hline
\end{tabular}

Note: Time Out is 24 hours later than date listed 


\section{Appendix N: Hydrolab Water Quality Measurements}

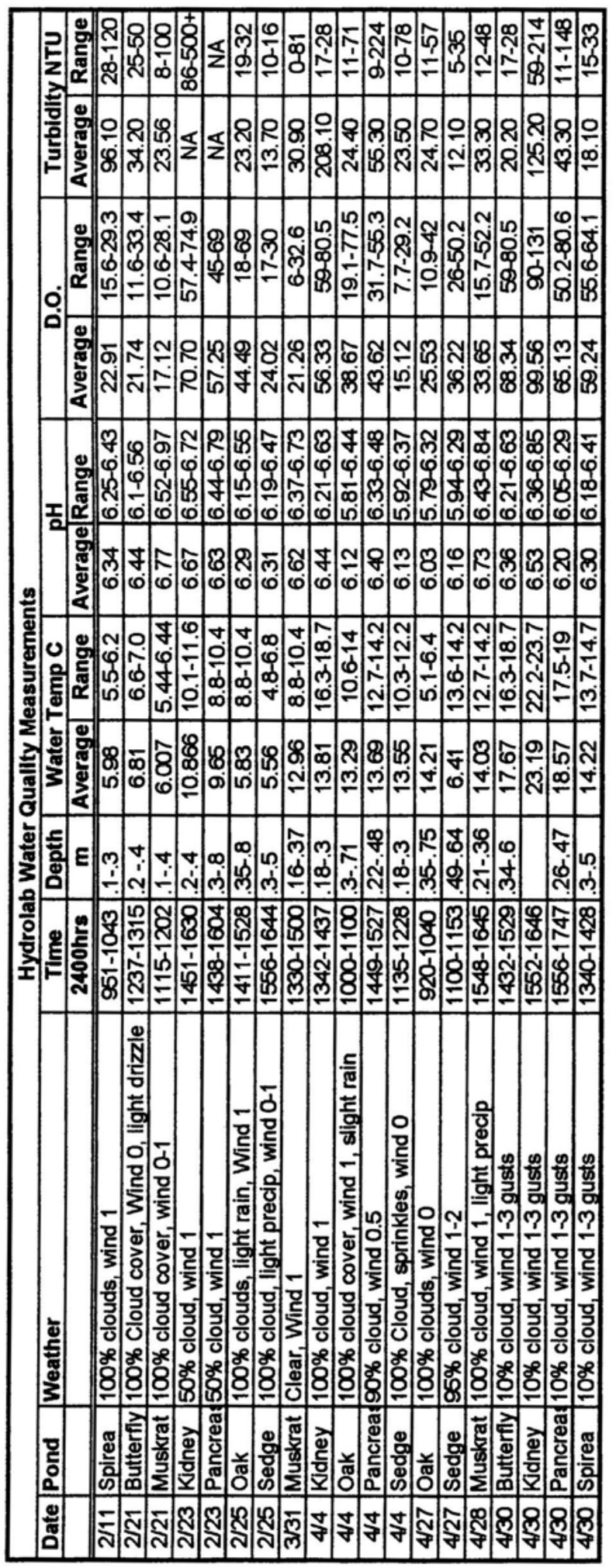

